Oil for Food Program: Implications of the UN Sanctions Regime for Human Rights in Iraq

By

Ayat El-Dewary, B.A. Hons

A thesis submitted to the Faculty of Graduate Studies and Research in Partial Fulfillment of the requirements for the degree of

Master of Arts

Department of Law

Carleton University

Ottawa, Ontario

September 2006

(C) copyright

2006, Ayat El-Dewary 


$\begin{array}{ll}\begin{array}{l}\text { Library and } \\ \text { Archives Canada }\end{array} & \begin{array}{l}\text { Bibliothèque et } \\ \text { Archives Canada }\end{array} \\ \begin{array}{l}\text { Published Heritage } \\ \text { Branch }\end{array} & \begin{array}{l}\text { Direction du } \\ \text { Patrimoine de l'édition }\end{array} \\ \begin{array}{l}\text { 395 Wellington Street } \\ \text { Ottawa ON K1A 0N4 }\end{array} & \begin{array}{l}\text { 395, rue Wellington } \\ \text { Ottana ON K1A ON4 } \\ \text { Canada Oa }\end{array}\end{array}$

Your file Votre référence ISBN: 978-0-494-18260-4 Ourfile Notre référence ISBN: $978-0-494-18260-4$

NOTICE:

The author has granted a nonexclusive license allowing Library and Archives Canada to reproduce, publish, archive, preserve, conserve, communicate to the public by telecommunication or on the Internet, loan, distribute and sell theses worldwide, for commercial or noncommercial purposes, in microform, paper, electronic and/or any other formats.

The author retains copyright ownership and moral rights in this thesis. Neither the thesis nor substantial extracts from it may be printed or otherwise reproduced without the author's permission.
AVIS:

L'auteur a accordé une licence non exclusive permettant à la Bibliothèque et Archives Canada de reproduire, publier, archiver, sauvegarder, conserver, transmettre au public par télécommunication ou par l'Internet, prêter, distribuer et vendre des thèses partout dans le monde, à des fins commerciales ou autres, sur support microforme, papier, électronique et/ou autres formats.

L'auteur conserve la propriété du droit d'auteur et des droits moraux qui protège cette thèse. $\mathrm{Ni}$ la thèse ni des extraits substantiels de celle-ci ne doivent être imprimés ou autrement reproduits sans son autorisation.
In compliance with the Canadian

Privacy Act some supporting forms may have been removed from this thesis.

While these forms may be included in the document page count, their removal does not represent any loss of content from the thesis.
Conformément à la loi canadienne sur la protection de la vie privée, quelques formulaires secondaires ont été enlevés de cette thèse.

Bien que ces formulaires aient inclus dans la pagination, il n'y aura aucun contenu manquant. 
"Let me conclude by saying that the humanitarian situation in Iraq poses a serious moral dilemma for this Organization. The United Nations has always been on the side of the vulnerable and the weak, and has always sought to relieve suffering, yet here we are accused of causing suffering to an entire population. We are in danger of losing the argument, or the propaganda war - if we haven't already lost it - about who is responsible for this situation in Iraq - President Saddam Hussein or the United Nations "' Kofi Annan.

${ }^{1}$ Quoted by V. Gowlland- Debbas (2001). United Nations Sanctions and International Law. The Hague: Kluwer Law International (Page 16). 


\begin{abstract}
The Security Council's response to the impact of economic sanctions against Iraq took the form of a humanitarian program called Oil for Food. While this humanitarian program did not result in the eradication of the devastating consequences of sanctions, its implementation violated the basic norms of international human rights and humanitarian law.
\end{abstract}

This thesis examines the human cost of the sanctions regime and the ineffectiveness of the Oil for Food Program. It investigates the role of the Security Council, more specifically the United States and the United Kingdom in "breaching" essential norms of international human rights and humanitarian law. It is posited that the U.S. and the U.K. have used the humanitarian program as a mask in disguise to diffuse a clean image to the international community while continuing their hegemonic vested interest in the region. From a theoretical point of view, the realist theory of international regimes is used as the main theoretical framework to illustrate the vested interest of states defined in terms of power relations. The study deploys Kindleberger's hegemonic stability discourse to analyze the role of the hegemon/stabilizer in establishing rules of an economic order.

While realizing the powerful status of the permanent members of the Security Council, it is important to recognize that their authority is not unlimited, and that they are also bound by international laws, which require them to prevent serious humanitarian crimes that degrade human dignity. This thesis explores the proposals for humanitarian ways of enforcing economic sanctions and relief programs, which comply with international human rights and humanitarian law. 


\section{Acknowledgements}

This thesis is dedicated to all the Iraqi women, children and men that have lost their lives, lost their loved ones and to those who continue to suffer. Your plight has not gone unnoticed and you will never be forgotten.

I want to take this opportunity to first and foremost thank God for giving me patience, courage and support to pursue such a compelling, resonant and heart wrenching issue given the current political crisis in Iraq today. I would like to begin by thanking Prof. Obi Aginam for all his advice and support throughout this research process. His knowledge and insight were of tremendous importance to this thesis.

My sincere love, appreciation and respect go to my amazing family that I am so grateful to have: my mother (Mariam Ramadan), father (Medhat El-Dewary) and brother (Sherif El-Dewary) whom without their prayers, continuous support and encouragement, I would not have done it without them. I would like to thank my loving husband (Sameh Abdalla) for his unconditional love, support and for always being my voice of reason and the edifice of strength that carries me forward.

I would like to extend my thanks to the Department of Law and especially to Andrew Squires who has always been there for me whenever I needed him. I want to also thank my very dear friend, Abiola Sunmonu for her continuous support and inspirational words. I also want to thank my dear friend, Lidvina Rajabalan who always listened to me with so much patience. I also would not have done this without my very dear friend, Tim Wilson for his continuous academic insight, kindness and patience. I also can not forget to thank Hans von Sponeck who was kind enough to share his own work, knowledge and experience of the Oil For Food Program with me.

There are so many people that have supported me throughout the last year and a half and I do not have enough space to mention each and every one of them but words and space cannot simply describe my appreciation and gratitude for their love, kindness and support. Thank you. 
Table of Contents

$\begin{array}{lll}\text { Abstract } & \text { iii }\end{array}$

Chapter I: Laying the Foundation: Concept and Purpose

of Economic Sanctions

I. Introduction

II. Economic Sanctions Defined 3

III. The Purpose of Sanctions 5

IV. Theoretical Perspectives on Economic Sanctions: Realist

$\begin{array}{ll}\text { Theory of International Regimes } & 7\end{array}$

IV. I. Anarchy 9

IV. II Hegemonic Stability Discourse 13

V. Conclusion

Chapter II: Hegemony or Humanitarian?: UN Economic Sanctions - A

Case Study of Iraq

I. Introduction

II. History of UN Economic Sanctions 19

III. Mini Case Studies $\quad 21$

IV. History of Iraq - Kuwait Political Relations 25

V. Economic Sanctions Against Iraq 26

V. I. August $2^{\text {nd }}, 1990-$ January $16^{\text {th }}, 1991$

V. II. Resolution $687 \quad 29$

VI. Oil for Food Program 31

VI. I. Oil for Food Program under Resolutions 706 and 712

VI. II. Oil for Food Program under Resolution 986

VI. III. Oil for Food Program Post Resolution 986

VII. Humanitarian Consequences of Sanctions and the Oil for Food $\begin{array}{ll}\text { Program } & 35\end{array}$

VII. I. Food, Health and Nutrition in Iraq 35

$\begin{array}{ll}\text { VII. II. Child Malnutrition } & 37\end{array}$

VII. III. Impact of Sanctions on Women $\quad 40$

VII. IV. Environmental Consequences $\quad 41$

VII. V. No Fly Zones $\quad 42$

$\begin{array}{ll}\text { VIII. Conclusion } & 44\end{array}$

Chapter III: The Legal Constraints of the Oil for Food Program 48

$\begin{array}{ll}\text { I. Introduction } & 48\end{array}$

II. International Humanitarian Law 49

III. International Humanitarian Law during Economic Sanctions $\quad 51$

III. I. The Right to Humanitarian Assistance $\quad 54$

III. II. Relief Supplies in Naval Blockades $\quad 55$ 
III. III. Protection of Objects Indispensable to the Survival of the Civilian Population (Protocol I, Article 54)

III. IV Protection of the Natural Environment (Protocol I, Article 55)

IV. International Human Rights Law $\quad 58$

IV. I. Universal Declaration of Human Rights $\quad 59$

IV. II. Charter of the United Nations $\quad 60$

IV. III. International Covenant on Economic, Social and Cultural Rights 61

$\begin{array}{ll}\text { Cultural Rights } & 61 \\ \text { IV. IV. International Covenant on Civil and Political Rights } & 63\end{array}$

V. Conclusion

64

Conclusion: Recommendations for New Sanctions Policy

67

I. Hans von Sponeck's Recommendations (Case of Iraq)

68

II. Alternatives and Recommendations For a New Sanctions Policy

\section{Appendices}

75

Appendix I: Oil for Food Program Chart and Security Council Resolutions $\quad 75$

Appendix II: List of Restrictions

79

Appendix III: United Nations Security Council Resolution $986 \quad 80$

Appendix IV: United Nations Security Council Resolution 661

Appendix V: United Nations Security Council Resolution 687

Appendix VI: Oil Ceiling and Sales Chart 97

Appendix VII: Disparities of Under Five Deaths Chart, UNICEF 98

Appendix VIII: Hans von Sponeck's Recommendations Report 99

$\begin{array}{ll}\text { Bibliography } & 125\end{array}$ 


\section{Chapter I: Laying the Foundation: Concept And Purpose of Economic}

\section{Sanctions}

\section{I: Introduction}

As a response to the Iraqi invasion of Kuwait on August $2^{\text {nd }} 1990$, the United Nations Security Council (“UNSC") imposed comprehensive economic sanctions against Iraq. Access to food, electricity, clean water and medication for the civic population was significantly limited during the sanctions regime. In 1991, it was reported that close to one million children were malnourished and as many as 100,000 were starving to death (Hans von Sponeck, 2006) ${ }^{1}$. In Iraq, economic sanctions stultified development work and hindered humanitarian aid.

In response to the catastrophic humanitarian conditions in Iraq, the UNSC decided to implement the Oil for Food ${ }^{2}$ (See Appendix I) under United Nations Resolution 706 in 1991. The Oil for Food program allowed for the sale of up to $\$ 1.6$ billion of Iraqi oil revenues over a 6 -month period to finance humanitarian operations under the supervision of the United Nations. This did not solve the problem as the program relied on the production of oil, which was hindered by the infrastructure that was destroyed during the

\footnotetext{
${ }^{1}$ Hans von Sponeck was Assistant Secretary-General of the UN and Coordinator of the Humanitarian Program (Oil-for-Food) in Iraq from 1998 to 2000. He resigned to protest the effects of sanctions on Iraqi people. I was invited to a dinner/gathering in Halifax on Feb. 26. 2006 where Hans von Sponeck was invited by Dr. Sheila Zurbrigg and her husband Professor Phillip Gerard. Hans spoke of his resignation and the failure of the humanitarian Oil for Food program. He gave me permission to quote him as needed in this study. Our conversation took place during the dinner/gathering on February 26, 2006

${ }^{2}$ As I begin to discuss the effectiveness of the Oil For Food Program throughout this thesis, it must be clear that I do not state that the OFFP was intentionally structured to violate norms of International Humanitarian Law. It is important to note that at the Program's conception, it was meant to alleviate the plight of the Iraqi population due to sanctions; however, its actual implementation was very ineffective.
} 
Desert Storm War and the continued American and British air strikes in the no fly zone areas in Iraq (Simons, 1998: 245 - 247). Furthermore, many necessary humanitarian goods and supplies were restricted (See Appendix II) from entering Iraq by the United Nations Security Council (mostly the United States and the United Kingdom) because of the unsubstantiated myth that Iraq would use these goods for the development of weapons of mass destruction.

Based on the sanctions imposed against Iraq (longest imposed sanctions in the history of the UN) and the relief/aid program that was implemented in response to the humanitarian problems, this thesis explores the rationale and legitimacy of UN Sanctions regime as well as the effectiveness of the Oil for Food program. A major problem that needs to be addressed is the predicament of the Oil for Food as a humanitarian program and how it was co-opted by the West while sacrificing the lives of many Iraqis, especially women and children.

This chapter lays out the theoretical framework for a detailed and constructive analysis of my research. The chapter is divided into two major sections. Section A focuses on the definitions and concepts of economic sanctions as well as a review of existing literature on the effectiveness and purpose of economic sanctions.

Section B explores the realist theory of international regimes, while focusing on the hegemonic stability discourse under the realist framework. This is pivotal as I explore how the language discourse of the Oil for Food program as "humanitarian" was manipulated and used as a tool of hegemony by its beneficiaries. I begin by giving a background to the realist theory of regimes. I will then examine and critique two major examples of the realist theory of regimes - anarchy and the hegemonic stability discourse 
while showing their relevance to my research. Furthermore, I explore how the discourse of hegemonic stability plays a major role in the work of multilateral institutions such as the United Nations (hereafter "UN"), more specifically, the UNSC.

\section{II: Economic Sanctions Defined}

Historically, the term 'sanctions' originated in Ancient Greece under Pericles' Megarian decree in $432 \mathrm{BC}$ in response to the "kidnapping of three Aspasian females" (Hufbauer, 1983:4). The decree limited "entry of Megara's products into Athenian markets" (Ibid: 23). Unfortunately, the lack of detailed historical records of sanctions in Greece limits further examination of its techniques, objectives and usage (Ibid: 4). The term 'economic sanctions' originated pre-World War I. During this time, 'economic sanctions' accompanied warfare and "fell under the rules of war" (Gordon, 2000: 123). For example, pre 1812 - 1814 war between the United States and Britain, the United States boycotted British goods in "response to British Naval Acts limiting U.S. trade with France” (Hafbauer, 1983: 24). After World War I, attention was sought to abandon warfare while imposing economic sanctions. It was not until post World War II, however that this notion changed and the objectives of sanctions were to substitute military action focusing on settling disputes through collective action.

After World War II, countries that imposed sanctions began to formulate a list of goals and objectives for the sanctions regime. Sanctions were regarded as an alternative to war, "an economic, peaceful, silent deadly remedy...the boycott is what is substituted for war" (President Woodrow Wilson quoted by Gordon, 2000:123). Sanctions were also regarded as efforts to threaten a country from occupying another country or as a way of targeting a country to withdraw its troops from occupied territories. Nowadays, the 
United States uses economic sanctions to "discourage the proliferation of weapons of mass destruction and ballistic missiles, promote human rights, end support for terrorism, thwart drug trafficking, discourage armed aggression, protect the environment, and replace governments" (Haass, 1998:1).

There are several types of sanctions. Although economic sanctions are the most popular; nevertheless, there are political, military, cultural and indirect sanctions (usually implemented under economic and military sanctions). Political and cultural sanctions are considered non-violent and diplomatic measures, whereas military sanctions are not. There are two types of economic sanctions - one is financial and the other is commercial and technical. The financial economic sanctions include measures such as reduction, suspension and cancellation of development and military assistance, voting against loans and freezing interest (Doxey, 1996:14). The commercial and technical economic sanctions include measures such as restrictive licensing of imports and exports, discriminatory tariff policy, cancellation of fishing rights, cancellation of joint projects and trade agreements and placing a ban on technology exports (Ibid 14).

Sanctions could be multilateral or unilateral. Multilateral sanctions are imposed by multiple states through "collective actions" (UN Charter, Chapter VII). An example of multilateral sanctions is through the United Nations. Unilateral sanctions, on the other hand, are defined as a "one state coercive actions" (Dajani, 1983: 123). An example of unilateral sanctions includes the Soviet Union's trade restriction on Yugoslavia, and the United States trade boycott of Cuba.

Sanctions, especially economic sanctions, are primarily aimed at compelling a sovereign state to change its political or military behavior. Sanctions are regarded as a 
"form of expression, a way to communicate official displeasure with a certain behavior or action" (Haass, 1998:2). It is a non-military action aimed at putting pressure on a state. As Haass explains, "sanctions provide a visible and less expensive alternative to military intervention" (Ibid: 2). Sanctions, according to Haass, involve less of a risk in terms of human casualty. Losman on the other hand defined economic sanctions as "penalties inflicted upon one or more states by one or more others to coerce the target nations to comply with certain norms that boycott initiators deem proper" (Losman, 1979:1), which clearly shows that "economic sanctions, rigorously applied and sustained over time, strike hardest at the most vulnerable" (Simons, 1998:34).

Assessing three definitions of economic sanctions, Baldwin argues that sanctions can have two contradicting functions. It is either used as a measure to enforce international law or it is used as a tool of governmental power relying on economic goals, thereby violating human rights while jeopardizing basic survival needs. Baldwin states that:

Economic sanctions have three common meanings: The first being a rather narrow concept referring to the use of economic measures to enforce international law. The second refers to the types of values intended to be augmented or reduced in the target state. Finally, the third corresponds to the concept of economic techniques of statecraft (Baldwin quoted by Doxey, 1996:8).

\section{III: The Purpose of Sanctions}

There are two broad principles identified by Crawford and Klotz to explain the purpose of sanctions. One is what they call the "theory of influence" and the second is the use of the "theory of influence" as a background to develop a hypothesis on the consequences of sanctions, whether intentional or not (Klotz \& Crawford, 1999:25). 
Under the first principle, three models are identified. First is the 'revolutionary' model, which is defined as "sanctions that weaken a regime so that it can be easily toppled and overthrown" (Stultz as quoted by Klotz \& Crawford, 1999: 26). Second is the 'thumbscrew' approach, where "costs of pursuing a policy are steadily increased to the point where targets have more to gain by change than by holding fast to the sanctioned policy" (Ibid 26). Finally is the 'evolutionary' model, which is the "effect of specific limited changes...that work through the target's social and political systems" (Ibid 26).

These approaches target states that are recognized as "a collective of decision making elites, vulnerable through their economy, a collection of institutions that require material resources and civil society (non state political organizations, unions, social groups and individuals within the target) and spillovers on global contexts" (Ibid 29). Sanctions target these states by threatening their military and invariably spread to all other sectors such as industrial, financial and technological resources; resources that may include oil and armaments.

Another approach postulates that economic sanctions are a form of war crimes because they are often discriminatory and target innocent civilians. As Gordon implies, "sanctions are the modern version of siege warfare: each involves the systematic deprivation of a whole city or nation of economic resources" (Gordon, 1999:124). Gordon argues that siege restricts the economy of a community by limiting or banning access to food, water and fuel; conceit of formal food exemptions. Moreover, in the case of siege warfare, civilian suffering is not considered 'collateral damage,' rather it is considered the primary goal of the siege strategy (lbid: 125). Therefore, sanctions can be considered siege warfare, as they undermine the civilian economy (i.e. livelihood) of a 
society and prevent production of necessities while harming the most vulnerable in the process.

\section{IV: Theoretical Perspectives on Economic Sanctions: Realist Theory of International Regimes}

In order to understand realism as a theoretical framework in international relations, Jack Donnelly's definition is helpful. Donnelly states that, "realism emphasizes the constraints on politics imposed by human nature and the absence of international government. Together, they make international relations largely a realm of power and interest" (Donnelly, 2000: 9). The most fundamental feature of a realist paradigm of international regimes/politics is the vested interest of states defined in terms of power relations (Morgenthau, 1978: 4). Realist theories of regimes "emphasize relative power capabilities as a central explanatory variable and stress states' sensitivity to distributional aspects of cooperation and regimes" (Hasenclever, Mayer \& Rittberger, 1997: 84). Realist theory, also known as the power-based approach, "assumes that states care not only for absolute, but for relative gains as well" (Ibid: 3 ).

There are four general principles associated with the realist school of international relations. The first is that the international system founded on states is anarchical in nature, where no other regulatory body or actor above states has the authority to control state behaviour. The "condition of international anarchy is viewed as a powerful structural constraint that limits the rational policy options of states to an extent that they are expected to behave in identical ways when confronted with similar situations" (Freyberg-Inan, 2004: 64). This leads to the second principle, which focuses on the 
sovereignty of nation states as the primary actors in international relations/politics, where the "name, size and organization of the competing groups alter over time [but] the essential nature of inter-group conflict does not" (Gilpin, 1986: 309). This emphasizes the notion of human beings as members of a group rather than individuals. The third principle postulates that the state's main objective to maintain and achieve security and survival is through power (economic and military), which is essentially achieved by military means. From a realist's paradigm, the state's main concern with military conflict is the threat it poses to its security, hence, states are expected "to try to maximize primarily, though not exclusively, their military power" (Freyberg-Inan, 2004: 65) as it is considered the "most important type of power resource" (Ibid: 65). The fourth principle projects states as pursuing their own interests and in doing so, "they are self-regarding and not other-regarding" (Taliaferro, 1999: 3).

Morgenthau, a leading exponent of realism, listed six principles of the realist paradigm in his book Politics Among Nations. The six principles do not conflict with the principles mentioned above. However, they "summarize a simple yet wide ranging philosophical, theoretical, and political world view" (Donnelly, 2000: 16).

- Political realism believes that politics, like society in general, is governed by objective laws that have their roots in human nature (Morgenthau as quoted by Donnelly, Ibid: 7),

- The main signpost that helps political realism to find its way through the landscape of international politics is the concept of interest defined in terms of power (Ibid: 5), 
- Power and interest are variable in content across space and time (Morgenthau as quoted by Donnelly, Ibid: $8-9$ ),

- Realism maintains that universal moral principles cannot be applied to the actions of states (Ibid: 10),

- Political realism refuses to identify the moral aspirations of a particular nation with the moral laws that govern the universe (Ibid: 10),

- The difference, then, between political realism and other schools of thought is real and it is profound...Intellectually, the political realist maintains the autonomy of the political sphere (Ibid: 10).

Morgenthau emphasizes an understanding in the connection between national interest and the desire to seek power by states, and that "there is a logically required connection between interest and foreign policy" (Ibid: 45). In the next section, I explore Waltz's concept of anarchy and how he fails to recognize this important link between interest and foreign policy that Morgenthau persuasively espoused.

\section{IV.I: Anarchy}

Anarchy is a prominent feature of the realist theory of international regimes. Anarchy is the absence of hierarchical order or "hierarchical relations of authority and rule" (Donnelly, 2000:81), which defines much of the international political system as claimed by realist theorists. Order, as suggested by Donnelly in the international system, is "established horizontally rather than vertically" (Ibid: 81 ). This implies that interactions amongst states are not enforced in an international political structure. The 
United Nations Security Council is suggested as an example of this anarchic order that is not enforced by hierarchical political institutions.

I argue otherwise because even though the UNSC may be placed under the anarchic order, the Power of the Veto exists in the UNSC, where "the five permanent members of the Security Council (China, France, Russia, U.K., and U.S.) enjoy the privilege of veto power" (www.globalpolicy.org accessed on Feb. $15^{\text {th }}$ 2006). This kind of power was used by the U.S. ${ }^{3}$ in the case of sanctions against Iraq. For example, the United States "vetoed the export of 66 containers of granite for hospitals and health care centers on the ground that such material was not a basic item" (Simons, 1998: 120) ${ }^{4}$. The veto power is being used as a hegemonic tool in what seems to be a hierarchical order imposed by the United States over the rest of the Security Council members. I am not implying that the international system is vertically operated. I am however, arguing that the abuse of veto power exists amongst the permanent Security Council members to achieve their economic and strategic interests, which shows that hegemony exists in an anarchical system.

In order to understand how "anarchy" operates in the international political system, there needs to be a deeper examination of "systems" theory and "structural" theory of realism that were developed by Kenneth Waltz. The main distinction between systems and structural theories is that under the systems theory, "balance of power politics prevail wherever two, and only two requirements are met: that the order be

\footnotetext{
${ }^{3}$ There is however an assumption that the United States may lead the way to a successful United Nations (Bucklin, 2000: 99).

${ }^{4}$ Footnoted by Simons as follows: S/25761, 12 May 1993; S/26204, 2 August 1993, United Nations, New York. For a detailed and full list of items vetoed by the UN Sanctions Committee (mostly the U.S. and the U.K.), See Appendix II.
} 
anarchic and that it be populated by units wishing to survive" (Waltz, 1979: 121), whereas structural theory assumes that anarchy and hierarchy exist in coalescence, hence, the balance of power cannot be formed. This balance of power defines the distinction between the international political realm (anarchic) and the domestic political realm (hierarchic). Waltz argues:

Structural questions are questions about the arrangement of the parts of a system. The parts of domestic political systems stand in relations of superand subordination.... Domestic systems are centralized and hierarchic. The parts of international political-systems stand in relations of coordination. Formally, each is the equal of all the others.... International systems are decentralized and anarchic (Ibid: 121).

Waltz distinguishes international systems in terms of units or what he calls, “ordering principles" (Lake, 2003: 305). Focusing on units in his systems theory, Waltz observed that:

Structure has to be studied in its own right, as do units. To claim to be following a systems approach or to be constructing a systems theory requires one to show how system and unit levels can be distinctly defined. Failure to make and preserve the distinction between structures, on the one hand, and units and processes, on the other, makes it impossible to disentangle causes of different sorts and to distinguish between causes and effects. Blurring the distinction between the different levels of a system has, I believe, been the major impediment to the development of theories about international politics (Waltz, 1986: 78).

Focusing on the parts or units of any given system, Waltz argues that systems theory explains the recurring formations of the balance of power. To Waltz, “international structures are defined in terms of an era, be they city states, empires or nations" (Waltz, 1979:91). Even though Waltz recognizes that "states are not and never have been the only international actors" (Ibid: 93), and for the theory to function, "two or more states must coexist in a self-help system" (Ibid: 118), he argues that one should not 
have a superior power, while the other may have more of a managerial role, such as the United States in post World War II (Waltz, 1979: 208), which would mean assigning it the role of a hegemon.

Waltz contradicts his own views, as he argues that the international system is anarchic moving away from his structural theory by rejecting any assumption of a hierarchic structure. He further argues, "states strive to maintain their autonomy and work to maintain a measure of independence and may even strive for autarky" (Ibid: 204). How can an international system be considered a completely anarchic structure that exists without hegemony? How can it not exist in hegemony when it strives to maintain independence and sovereignty separate from the rest of the states? In an international system, "hegemony passes from one power to another and is constantly subject to dispute" (Bull, 1995: 11). With hierarchy and anarchy, hegemony follows, making the balance of power shift, hence, omitting the notion of absolute anarchy and disregard of hegemony in the international system.

Another problem with Waltz's systems theory is that he claims that only two ordering principles are needed, anarchy and hierarchy. He believes that these two principles do not complement one another; rather they act as a dichotomy. In doing so, Waltz disregards some key factors of a political system: state interests and motives. Morgenthau recognizes a state's desires to seek power and finds "the eternal laws by which man moves in the social world" (Morgenthau as quoted by Donnelly: 2000:57) extremely relevant to the realism discourse. Waltz tends to focus on how anarchy imposes specific behaviors to state structures regardless of motives. This is problematic as he discounts the notion of hegemony, which plays a major role to shape the behaviour 
of states. This leads to another dimension of the realist theory of regimes, the relevance of hegemony in state behaviour.

\section{II: Hegemonic Stability Discourse}

One of the most prominent features of the realist theory of international regimes imperative to this research is hegemonic stability. Hegemonic stability discourse was first introduced by Charles Kindleberger in the 1970s in his work on the Great Depression of the 1920s and 1930s. Kindleberger argues that, "for the world economy to be stabilized, there has to be a stabilizer, one stabilizer" (Kindleberger as quoted by Hasenclever, Mayer \& Rittberger, 1997: 88) and that "the overwhelming dominance of one country is necessary for the existence of an open and stable world economy" (Milner, 1998: 113). The hegemon/stabilizer uses their role of dominance and power to assume the role of the humanitarian and altruistic. Kindleberger's theory focuses "on the role of leading states -for example, Great Britain in the nineteenth and the United States in the twentieth centuries" (Milner, Ibid).

Hegemonic stability focuses on:

The role of a single dominant power in establishing and maintaining the norms and rules of a liberal economic order. The hegemonic state lays down liberal rules, creates international organizations to monitor them, and acts as crisis manager, becoming a lender of last resort when needed and a market for distress goods in times of economic recession. The system's openness is a function of the hegemon's capabilities (Kapstein, 1999: 465).

Robert Cox's analysis of Gramsci's notions of hegemony and power is an

essential feature of the hegemonic stability framework. According to Cox, hegemony

is an order within a world economy with a dominant mode of production, which penetrates into all countries and links into other subordinate modes of production. It is also a complex of international social relationships, 
which connect the social classes of the different countries. World hegemony is describable as a social structure, an economic structure, and a political structure; and it cannot be simply one of these things but must be all three. World hegemony, furthermore, is expressed in universal norms, institutions and mechanisms which lay down general rules of behaviour for states and for those forces of civil society that act across national boundaries - rules which support the dominant mode of production (Cox, 1993: 61).

The U.S. in post Cold-War era is an example of a global hegemon based on Cox's interpretation of Gramsci's model of hegemony. It has played the role of a hegemonic power by creating international and multilateral institutions that promote U.S. interests and economic power around the world in the name of human rights. As Mastanduno observed, "the concept that best captures America's post war foreign policy goals is not containment but multilateralism" (Kapstein, 1999: 466). Multilateral institutions such as the UN, more specifically, issues that are negotiated under the UNSC, have reflected the interests of the U.S. The "confusingly one sided message that has been sent by the most powerful state in the world is that human rights are conceived as almost exclusively an instrument of foreign policy" (Falk, 2000: 39).

This was shown in the case of the Oil for Food program where for many years, essential goods were restricted from entering the country by the United States ${ }^{5}$ using the excuse of weapons of mass destruction as an unfounded affirmation (Blix $\left.{ }^{6} 2004: 8\right)$, while Iraqi oil money was continuously being used to fund the supposed "humanitarian"

\footnotetext{
${ }^{5}$ I would like to note and clarify that I am not suggesting that the U.S. acted unilaterally, even though that it was the Security Council's decision as a whole to impose sanctions against Iraq, the U.S. and most of the times, the U.K. abused this multilateral institution by manipulating Security Council's decisions.

${ }^{6}$ Hans Blix was the former Director of the UN Weapons Inspection Commission on Iraq
} 
program, UN employees (von Sponeck, ${ }^{7}$ Feb. 2006) and the American economy.

Essentially, the hegemonic stability discourse implies that:

The United States was able to restructure the western economy according to its preferences after World War II because of its market size and its control over hard currency and critical resources, especially food and fuel...while the world has grown less dependent on America's natural resources (indeed, the United States has become more dependent on petroleum and raw materials) (Kapstein, 1999: 467).

The U.S. had continuously implied that the economic embargo against Iraq and the bombing of Iraqi no fly zone areas would continue regardless of Iraq's compliance with Resolution 986, which will be discussed in more detail in the next Chapter (See Appendix III). Madeline Albright, U.S Secretary of State once said, "we do not agree with those nations who argue that if Iraq complies with its obligations concerning weapons of mass destruction, sanctions should be lifted" (Albright as quoted Simons, 1998: 243) implying that "dialogue may be possible but even then there would be no predictable end to the economic embargo" (Ibid: 243). The "American economy has a one-sided or non-complementary relationship, to the international economy" (Kapstein, 1999: 467). In the case of Iraq, it is quite obvious how crucial it is for the U.S. to use its "super power" status "to maintain a military and commercial grip on an oil rich region; to develop a multifaceted strategy that will continue to deter any effective challenge to the American hegemony" (Simons 1998: 248).

\section{V: Conclusion}

The theoretical perspectives discussed in this chapter underpin the nexus between the Oil for Food Program and its manipulation as a hegemonic tool by the United States

\footnotetext{
${ }^{7}$ See footnote number 1 .
} 
exploiting the UNSC Resolutions. Although the concepts and principles that I have outlined to explain the purpose of economic sanctions are not directly related to the realist theory of international regimes, they nonetheless offer critical insights on the abuse of sanctions in the international system marked by uneven power relations between strong and weaker states. These concepts and principles show how economic sanctions restrict the economy from functioning properly by destabilizing the civilian livelihood and thwarting humanitarian assistance.

Through the examination of the realist theory of international regimes, two major perspectives emerge - anarchy and hegemonic stability. Anarchy defines much of the international political system; an important example used by realist theorists is the United Nations Security Council. Even though, the international system functions horizontally (in an anarchy) with no centralized enforcement, there is some form of hierarchy still attributable to the international system, especially in the form of abuse of the UNSC by the permanent five. This is shown under the second example of hegemonic stability where it identifies the dominance of one country as necessary for the essential stability to the world economy.

In an international system, the enforcement of rules is carried out by states in the absence of a centralized authority, "which may resort to acts of self-help, including acts of force, in defense of their rights under operational, moral or legal rules" (Bull, 1995: 69). The important factor to recognize is that the enforcement of the rules is uncertain because of the limited solidarity level between states (Bull, Ibid: 69). Therefore, states assume the role to legitimize the rules for themselves "by employing their powers of persuasion and propaganda to mobilize support for them in world politics" (Ibid: 69). It is 
important to mention the veto power as an essential tool of enforcement that is used by the five permanent members of the Security Council regardless of support or acceptance given by the rest of the states or international assemblies and organizations. In the case of Iraq, the United States played a crucial role using the UNSC as an instrument of influence and power in enforcing its rules on the functionality of economic sanctions imposed on Iraq and in the revenues extorted from the Oil for Food program.

In Chapter Two, I contextualize the theoretical issues identified in this chapter by giving a succinct background and examination of UN economic sanctions that have been imposed in the past in comparison to the ones imposed against Iraq. Further, I explore the oil for food program in detail, especially its devastating humanitarian consequences, to show the predicament of the program as a humanitarian measure. 


\section{Chapter II: Hegemony or Humanitarian?: UN Economic Sanctions - A Case Study of Iraq}

\section{Introduction}

In order to understand the complexity and consequences of the economic sanctions on Iraq, this Chapter gives a descriptive overview of the other economic sanctions imposed by the UN in the 1990s. This will assist in understanding the methods used for the evaluation of the effectiveness of economic sanctions and sanctions measures. This Chapter evaluates the effectiveness of the Oil for Food Program that was created as a 'humanitarian' agenda during the Iraqi sanctions.

This Chapter highlights a few case studies involving economic sanctions by the UN to show the difference in the application of UN economic sanctions in Iraq and the rest of the other targeted countries. Iraq is used as the principal case study in this Chapter and throughout the research essay having suffered the most under UN economic sanctions. Following the historical review of economic sanctions, a more detailed background to the Iraqi case will be explored. This Chapter explores why sanctions were imposed on Iraq focusing on a brief overview of Iraq-Kuwait relations and the Gulf War. The Chapter focuses on the chronology of sanctions and the creation and implementation of the Oil for Food Program within its different phases, as well as the humanitarian consequences of the sanctions regime and the Oil for Food Program.

This Chapter re-evaluates our understanding of a humanitarian program and offers a critical analysis of economic sanctions as a catastrophic alternative to war rather than a peaceful alternative to violence. 


\section{II: History of UN Economic Sanctions}

The United Nations Security Council imposed sanctions twice in the first 45 years of its existence between 1945 and 1990 against Rhodesia in 1966, and South Africa in 1977 (Lopez, 2000:2). For the United States, however, economic sanctions were becoming the "policy tool" (Haass, 1998) in post-Cold War era. The United States is known as "the most prominent practitioner of peace time restrictions on trade and other economic transactions" (Lleyton, 1987:255). It has maintained sanctions in over 35 countries just between 1993 and 1996 (Gordon, 1999:123).

Since then, the technical implementation of sanctions has been complicated, as the process of enforcement of mandatory UN sanctions requires Security Council's authorization. This is an example of an imbalance that exists in who makes decisions about who is sanctioned and for what reasons. As argued by Doxey, "mandatory UN sanctions require Council agreement....this agreement ensures that permanent members will never be targeted" (Doxey, 1996:1). Yet, Doxey fails to recognize further that this imbalance of power might be inherently oppressive on poorer countries.

The use of sanctions on a multilateral level between 1945 and 1990 was minimal. The South African case was deemed unique as multilateral UN sanctions began with the internal opposition against apartheid and "the call for isolation were part of the overall political strategy of the internal black oppression" (Maloka, 1999:178). The UN General Assembly passed Resolution 1761 on November $6^{\text {th }}, 1962$ condemning the South African government of its racist apartheid policies, and on November $4^{\text {th }} 1977$, the UN Security Council called for a mandatory arms embargo against South Africa under Resolution 418 
following its "illegal assistance to Rhodesia and the continued control of Namibia" (Doxey, 1987:124).

There is no denial of the fact that part of the economic crisis of the acceleration of unemployment and poverty in South Africa was caused by economic sanctions. In addition to the economic crisis, South Africa has had a history of oppression and apartheid that made it hard to sustain itself with the economic sanctions and economic global changes. An effective sanction mechanism in South Africa was believed to be both cultural sanctions, more specifically, the sports boycott that was encouraged as the isolation of "apartheid sport elicited a very high level of national and international participation" (Black, 1999:213) and diplomatic sanctions, which entailed the "refusal of the United Nations to allow the participation of the apartheid Government of South Africa in its operations" (Bossuyt 2000: 6). South Africa became isolated internationally forcing the fall of the apartheid government.

In the 1990s after the Gulf War, the implementation of sanctions was launched at an extensive level. Economic sanctions "emerged as one of the major tools of international governance" (Gordon, 1999:123). At the end of the Gulf War in 1991, the Security Council approved Resolution 687, which maintained economic sanctions over Iraq. Two years after Resolution 687 was passed, the Council imposed comprehensive and partial sanctions against 11 countries. These countries were: Iraq (1990), Yugoslavia (1991, 1992, 1998), Libya (1992), Liberia (1992), Somalia (1992), Khmer Rouge controlled areas of Cambodia (1992), Haiti (1993), National Union for the Total Independence of Angola (1993, 1997, 1998), Sudan (1996), Sierra Leone (1997), Rwanda (1994) and Afghanistan (1999) (Lopez, 2000: 53). 
The next section will focus more closely on the post-1990s experience to analyze the usage and effectiveness of sanctions by presenting comparable case studies on sanctions. This section is vital because it shows the abuse of sanctions by comparing the Iraqi sanctions with the other sanctions imposed by the UN.

\section{III: Mini Case Studies}

Haiti: In June 1993, the UN Security Council imposed a fuel and arms ban on Haiti to restore a democratically elected government (Lopez, 2000:89). Measures that were taken included a third stage of imposing fuel and arms embargo with a naval blockade, flight ban and freezing of the assets of all military junta and their families (Ibid: 90). Security Council passed Resolution 940 "authorizing the creation of a multinational force and the use of all necessary means to restore Aristide." The impact of military use and economic sanctions resulted in an increase in child mortality, destruction of hospitals and schools, loss of jobs, and a spiraling inflation with basic food staples. Rice and corn prices increased by 137 percent and 185 percent, respectively, between 1991 and 1994 (Gibbons as quoted by Lopez, 2000: 90) beyond the reach of what most poor Haitians could pay.

Yugoslavia: The UN Security Council imposed sanctions against Yugoslavia three times during the 1990s. The first was in September 1991, an arms embargo in response to the war between Serbia and Croatia. The second were comprehensive economic sanctions in May 1992 in response to the war in Bosnia-Herzegovina. Finally, an arms embargo was imposed in March 1998 in response to the Kosovo crisis. Measures that were taken 
included a suspension of all arms sales and transfers, banning all international trade with Yugoslavia, prohibiting air travel, blocking financial transactions, banning sports and cultural exchanges, and suspending scientific and technical cooperation (Lopez, 2000:67). The impact of sanctions and war resulted in deterioration of water as chemical treatment was banned from entering the country as well as medicines. Child mortality increased and the economic situation deteriorated as inflation increased to 9,000 percent in 1992 (Ibid: 73-75).

Sierra Leone: Sanctions in Sierra Leone, along with Angola, were imposed in the midst of a civil war. In May 1997, the Armed Forces Revolutionary Council overthrew the elected government of Ahmed Kabbah and established a military junta headed by Major Johnny Paul Koromah. In August 1997, the Economic Community of West African States (ECOWAS) responded to the coup by imposing comprehensive economic sanctions. In October 1997, the UN Security Council imposed their own economic sanctions under Resolution 1132 (Ibid: 167). Measures included arms embargo on Sierra Leone and travel sanctions on the AFRC headed by Koromah. International sanctions that were imposed by the ECOWAS and Security Council have been marked as a failure in its restoration of peace as the timing of the enforcement of sanctions was crucial. Sanctions were not able to prevent the rebels from expanding militarily. The results were crucial as sanctions only perpetuated the halt in commercial and humanitarian relief deliveries. In May 1997, Sierra 
Leone had an estimated " 10,000 to 14,000 metric tons of food aid; these were only able to meet 40 percent of Sierra Leone's food needs" (Lopez, 2000:175). The human cost of war and sanctions was 50000 to 75000 from 1991 to 1999 (Human Rights Watch Report, 2000). Two thirds of these deaths occurred during sanctions between 1997 and 1999 (Lopez, 2000: 176).

Rwanda: The history behind the struggle between the Hutus and the Tutsis has been ongoing and enormous. This was shown during the horrific genocide in 1994, when Hutu extremists killed more than 500, 000 Tutsis and Hutu moderates in less than three months (Human Rights Watch, 1994). The world watched as the genocide took place. The United Nations Assistance Mission in Rwanda failed to keep the peace or protect the victims, thus, Security Council resorted to imposing an arms embargo in May 1994. They passed Resolution 918, which "prohibited the sale or supply to Rwanda of weapons and military related material" (Lopez, 2000: 195). The imposition of sanctions in Rwanda seemed ridiculous, as it was already too late for an arms embargo and too little was to be done with that to restore peace. Sanctions against Rwanda failed miserably and the human price from the genocide was already too large to deal with let alone sanctions' failure of enforcement.

Libya: UN Security Council imposed sanctions against Libya as a means of combating terrorism in March 1992; sanctions were imposed for 7 years. Measures that were taken included sanctions against aviation and 
armaments, banning the supply of weapons, restriction on the travel of Libyan officials and national and freezing of Libyan government assets abroad (Lopez, 2000: 110). There have not been many reports that have shown much humanitarian consequence in Libya because of sanctions. However, reports of traffic fatalities increased as a result of an increase in the use of roads, as emergency aviation was restricted. Libyan officials have stated that there has been an 11 percent increase in the unemployment rate as an economic consequence because of the embargo (Ibid: 116).

Iraq $^{8}$ : Iraq illegally occupied Kuwait on August $2^{\text {nd }} 1990$, immediate and strong measures were taken to enforce sanctions; an oil embargo and food imports were banned by the Security Council while naval and air blocks were enforced by the U.S. and Great Britain. On November $29^{\text {th }}, 1990$, Security Council passed Resolution 678 authorizing the use of all necessary means to liberate Kuwait (Ibid: 37). Sanctions continued causing a terrible humanitarian crisis within Iraq in the 90 s till the second U.S. led war on Iraq on March $19^{\text {th }}, 2003$.

Sanctions in the 1990s legitimized the enforcement mechanism of the international legal system without the use of military force. In Iraq, Yugoslavia and Haiti, however, sanctions gave way to the use of military force (Ibid: 53). Moreover, in the African cases, "Angola, Liberia, Rwanda, and Sierra Leone, UN sanctions appeared to

\footnotetext{
${ }^{8}$ It is important to note that pre-Gulf War, Iraq was already at war with Iran, which caused a humanitarian crisis that the Iraqi government had to acknowledge and bear responsibility to its citizens before invading Kuwait.
} 
have little influence on the use of force by various national and regional parties" (Lopez, 2000: 53). It is only in Libya that sanctions appeared to "accomplish objectives without military confrontation" (Ibid: 53). Therefore, the notion of sanctions as a soft alternative to war and military use seems vague and questionable.

\section{IV: History of Iraq-Kuwait Political Relations}

Prior to WWII, Iraqi oil was an important factor in international politics. The "Ottoman Empire first demonstrated its interest [in Iraq] when the Turkish Caliph acquired ownership of the oil" (Bell, 2004: 132). From the late 1800s, Kuwait had been shown as part of Iraq on the Ottoman maps. In 1899, Britain signed a pact with Kuwait establishing a British protectorate over the area to protect its business routes to India. In 1913, the border between Iraq and Kuwait was secured in a treaty between Britain and the Ottoman Turks.

The Ottoman-British Agreement of 1913 recognizes Kuwait as a District under the jurisdiction of the Province of Basra. Since sovereignty over Basra has been transferred from the Ottoman state to the Iraqi state, that sovereignty has to include Kuwait under the terms of the 1913 Agreement. Iraq has not recognized any change in the status of Kuwait (Schoenman, 1992: 6-11).

During WWI, the British invaded Iraq and was given a mandate by the League of Nations over Iraq from 1920 until 1932. To weaken Iraq's sovereignty, Britain blocked Iraq from the Persian Gulf in 1921 by carving Kuwait out of Iraq. The British Colonial Office carved Kuwait out of Iraq "after World War I to preserve Western interests in the region's oil industry" (Hassan 2001:195). The coastal access, which is significant for the advancement of each country's economic enhancement and development as a nation became the focal point of creating tension between Kuwait and Iraq. The coastal access 
"over which Kuwait maintained control had historically belonged to Iraq and had comprised Iraq's principal ports of sea access" (Hassan 2001: 195). Iraq was given its independence from Britain in 1932.

From 1955 to 1958, there were appeals from Iraq for the return of Kuwait to its boundaries. In 1958, General AbdelKarem Qassim overthrew the Iraqi monarchy and added pressure for the return of Kuwait to Iraq. Following by these events, Britain granted Kuwait full independence in 1961. However, Iraq refused to recognize Kuwait as a separate country from Iraq. This conflict continued over the sovereignty of the two strategic islands of Warba and Bubiyan in the Persian Gulf. It was not until 1963 when Qassim was killed and his government overthrown by the Baath Party that Iraq formally recognized Kuwait's independence.

\section{V: Economic Sanctions Against Iraq}

V. I: August $2^{\text {nd }}, 1990-$ January $16^{\text {th }}, 1991$

On August $2^{\text {nd }}, 1990$, Iraq invaded and illegally occupied Kuwait. The opposition to Iraqi aggression was international, "coming not just from the United Nations, but the Gulf Cooperation Council, the League of Arab States, the Organization of the Islamic Conference, the European Community and many others" (Lopez \& Cortright 2000:37).

Within hours of the news of the Iraqi invasion, the Security Council adopted Resolution 660 that condemned Iraq's invasion of Kuwait and demanded the immediate withdrawal of all Iraqi forces from Kuwait and for both countries to renegotiate their positions and differences. The United States then took immediate and forceful steps by imposing bilateral economic sanctions on Iraq and Kuwait (Melby, 1998:109). This meant the freezing of all Kuwait's assets under U.S control anywhere in the world and 
the freezing of Iraqi assets in the country (Melby, 1998: 109). The United States further imposed comprehensive economic sanctions on both Iraq and Kuwait. President George Bush "invoked his authority to implement the embargo under the International Emergency Economic Power Act, the National Emergencies Act, the Export Administration Act and the Arms Export Control Act" which provided the President with authority “over exports, imports and financial transactions" (Ibid: 109).

Also on the same day, French Iraqi and French Kuwaiti financial transactions such as foreign exchange transactions and transfer of funds were subjected to government permission. German Federal Government eventually followed by freezing all Kuwaiti accounts and deposits and suspended export guarantees (Simons 1998: 37). Several European and Asian countries took similar actions.

Four days later, the UN Security Council passed Resolution 661 (See Appendix IV), imposing comprehensive sanctions on Iraq and forming a sanctions committee under its chapter VII authority. The comprehensive sanctions included a ban on "all trade, an oil embargo, freezing of all Iraq's financial assets abroad, suspension of international flights and an arms embargo" (Alnasrawi, 2001:208). All shipping on the Shat-Al-Arab ${ }^{9}$ waterway was intercepted and "all vessels approaching the Jordanian port of Aqaba were boarded and inspected" (Lopez \& Cortright, 2000:39-40).

States were called upon to prevent import of all commodities and products originating in Iraq or Kuwait into their territories; the transfer of all funds to Iraq or Kuwait for trading purposes was prohibited; the supply of all goods except supplies intended strictly for medical purposes, and in humanitarian circumstances, foodstuffs - to Iraq and Kuwait was prohibited (Resolution 661- www.un.org accessed on May. $13^{\text {th }} 2006$ ).

\footnotetext{
${ }^{9}$ Shat-Al-Arab in South of Iraq
} 
Food imports were banned as the Security Council did not formally acknowledge or recognize it in Resolution 661. Furthermore, the White House commented on the food ban on August $13^{\text {th }}$ by saying, "it appears far too early to consider any foodstuffs as being in the humanitarian need category" (www.iie.com accessed on May. 13 ${ }^{\text {th }} 2006$ ). Even though, it was quite obvious with the frozen assets and blocked oil revenues that it became more difficult for Iraqi people to purchase or sell food, as they were used to importing $70 \%$ of their food needs. By mid August, the transport of food across the Turkey-Iraq border was brought to a standstill and by December $5^{\text {th }}$, a testimony before the U.S. Senate committee on Foreign Relations, reported that the embargo had effectively "shut off $90 \%$ of Iraq's imports and 97\% of its exports" (New York Times, 1990: A16 quoted by Alnasrawi 2001:209).

The trade embargo continued and on November $29^{\text {th }} 1990$, the Security Council adopted Resolution 678 "authorizing member states to use "all necessary means" to liberate Kuwait and gave Iraq a 'pause of goodwill' to comply with UN demands until January $15^{\text {th }}, 1991$ " (www.un.org accessed on May. $13^{\text {th }} 2006$ )

On January $16^{\text {th }} 1991$, a day after the ultimatum expired, coalition forces headed by the U.S. started a 6-week intense military campaign against Iraq that began with an air campaign followed by a ground war that ended in Iraq's retaliation and evacuation of forces from Kuwait. A total of 88,000 tons of bombs were dropped on Iraq, an explosive equivalent to seven Hiroshima size atomic bombs (Simons, 1998:4). Iraq was being "subjected to the equivalent of one atomic bomb a week, a scale of destruction that has no parallels in the history of warfare" (Ibid: 4). A special UN Mission to Iraq examined 
and assessed the intensity of the bombing after the war and this was the mission's conclusion:

It should, however, be said at once that nothing that we had seen or read had quite prepared us for the particular form of devastation which has now befallen the country. The recent conflict had wrought near apocalyptic results upon what had been until January, 1991, a rather highly urbanized and mechanized society. Now, most means of modern life have been destroyed or rendered tenuous (UN, 1996: 186-88 quoted by Alnasrawi).

This sustained six-week bombing of Iraq achieved its objective in driving Iraq out of Kuwait and in forcing Iraq to retrieve their aggression. Following the desert storm war, the Security Council adopted Resolution 687, referred to as "mother of all resolutions" (Lopez \& Cortright, 2000:42).

\section{II: Resolution 687}

On April 3, 1991, the Security Council adopted Resolution 687 (See Appendix V). Resolution 687 is known as the most complicated set of conditions that the Security Council had ever adopted. This Resolution contained "twenty six pre-ambular paragraphs and thirty four operative paragraphs" (Lopez \& Cortright, 2000:42). The Resolution ostensibly aimed to establish a cease-fire and to lay out a set of extensive conditions for lifting sanctions.

With Resolution 687 (1991), the Security Council outlined eight distinct conditions for Iraq to abide by in order for sanctions to be lifted. The requirements focused on stopping any proliferation of chemical and biological weapons, destruction of Iraq's weapons of mass destruction, paying Kuwait reparations for war damages and not supporting any kind of international terrorism. Resolution 687 focused on the: 
- "Recognition of Kuwait's territorial integrity and newly demarcated international borders with Kuwait,

- "Acceptance of a demilitarized zone with UN peacekeepers along the Iraqi-Kuwaiti border,

- "The monitoring and destruction of all chemical, biological and ballistic missile weapons and acceptance of a permanent ongoing monitoring program managed by the United Nations,

- "The monitored elimination of nuclear weapons materials and capabilities, supervised by the International Atomic Energy Agency (IAEA),

- "The return of all property stolen from Kuwait,

- "Acceptance of war damage liability and a compensation fund managed by the UN,

- "Repatriation of all Kuwaiti and third party nationals,

- "A pledge not to commit or support any act of international terrorism" (Lopez \& Cortright, 2000:42).

The Security Council decided to "review Iraq's compliance with the new requirements every 60 days to determine whether to lift or modify the sanctions" (AlNasrawi 2001:210). In the meantime, this new Resolution introduced new modifications to the importation of foodstuffs to Iraq. Iraq was allowed to sell a limited amount of oil to pay for the imported food, however, the new modification made no difference in the lives of Iraqis, as the substitutes were very low due to this prescribed endemic destitution. This continued until the implementation of the Oil for Food 
Program (OFFP) $)^{10}$. As the impact of sanctions on Iraqi civilians increased, the international support for sanctions began to erode. The creation of the OFFP was critical for the continuation of economic sanctions against Iraq. The U.S. and the U.K. under the UNSC voted for the creation of the program.

\section{VI: Oil for Food Program}

\section{I: Oil for Food Program under Resolutions 706 and 712}

The humanitarian conditions in Iraq were becoming catastrophic. Security Council adopted Resolution 706 on August 15 $5^{\text {th }}, 1991$ under the Oil for Food Program. The Oil for Food program allowed the sale of up to $\$ 1.6$ billion of Iraqi oil revenues over a 6-month period to finance humanitarian operations under the supervision of the United Nations. The Resolution also stated that in addition to funding humanitarian needs, Iraq would return Kuwaiti property, "make appropriate payments to the United Nations Compensation Fund", "cover half the costs of the Iraq-Kuwait Boundary Demarcation Commission," as well as United Nations' operation costs.

This would leave a small proportion from the $\$ 1.6$ billion dollars (after deductions: $\$ 1$ billion dollars) available for Iraq's humanitarian needs, which was deemed inappropriate for Iraqi civilians' well being. Its inadequacy was further proved by the UN Secretary General's executive delegate report that had estimated that "to provide food and medicines, and to restore some basic services including sanitation,

\footnotetext{
${ }^{10}$ The Oil for Food Program was considered a humanitarian program. It should not be considered as so because there is no external funding for food, medicine or clothing under this program. It is solely applicable only if Iraq agrees to sell oil in return for receiving goods that may or may not be approved by the Sanctions Committee.
} 
[Iraq] would need expenditure of about $\$ 6.8$ billion over a 12 month period" (Simons, 1998:102).

A month later, on September $19^{\text {th }} 1991$, the Security Council adopted Resolution $712^{11}$. This Resolution reaffirmed the concern over the nutritional and health of the Iraqi civilians and called on all states to "operate fully" in its implementation of the Oil for Food Program.

VI. II: Oil for Food Program under Resolution 986

As a continuation of the two previous Resolutions, the Security Council passed Resolution 986 (See Appendix III) on April $14^{\text {th }} 1995$ in response to the escalating humanitarian disaster that was taking place in Iraq. The Security Council established a new base for the Oil for Food Program. This Resolution permitted the sale of Iraqi oil with up to $\$ 2$ billion dollars in revenue every 90 days ( 3 months). Much of this money was allocated to provide funding for the United Nations operations and for the Compensation Fund. It was also "designed to increase the money involved, to change the distribution monitoring mechanisms, and to change the proportions that would be allocated to specific purposes" (Simons, 1998:103).

Even though this Resolution looked more progressive because the amount of funding had increased from the 1991 Resolutions, all other conditions, however, had yet to change. Therefore, the estimated costs that Iraq was left with for humanitarian relief (food) under Resolution 986 was $\$ 1.3$ billion dollars every six months for a population of over 20 million (UNICEF, 1998:18) from 1991-1998. Evidently, this resolution seemed to ridicule the Iraqi population. It was unfair and inadequate in serving Iraqi women,

\footnotetext{
${ }^{11}$ Passed 13 to 1 (Cuba) with one abstention (Yemen) (www.un.org accessed on May. 13 ${ }^{\text {th }}$ 2006)
} 
men and children with any kind of relief as after calculations and deductions were made, an Iraqi would end up with 29 cents a day (UNICEF, 1998). Hence, it was not a surprise that the Iraqi government rejected Resolution 986.

The Iraqi government decided to renegotiate their position with the United Nations Security Council after the Iraqi dinar devaluated. It was not until then that they had recognized the ferocious cycle of the silent war that was taking place over the Iraqi population due to sanctions. An agreement, in May 1996, was made over the implementation of the Resolution. The Resolution was implemented with a signing of a Memorandum of Understanding between the United Nations Secretariat and the Iraqi government. The Program went into effect on December $10^{\text {th }} 1996$ when the first Iraqi oil was exported and the first shipment of food arrived in Iraq in March 1997.

\section{III: Oil for Food Program Post Resolution 986}

Due to an international outcry over the humanitarian disaster in Iraq, the Security Council passed Resolution 1153 in 1998 allowing an increase (by raising the ceiling) of oil sales to over $\$ 5.2$ billion dollars (Alnasrawi, 2001: 213). In 1999, the Security Council passed Resolution 1284, which dropped the ceiling on Iraqi oil exports altogether. Even though, the ceiling was completely lifted, it did not improve the Iraqi population's perpetuating endemic, the sales were actually lower (See Appendix VI).

In a press release in March 2000, United Nations Secretary General stated that, "even if the Oil for Food Program is implemented perfectly, it is possible that our efforts will prove insufficient to satisfy the population's needs" (Bossuyt, 2000:16). The Iraqi population's social and economic situation continued to deteriorate as the Oil for Food Program continued and as sanctions lasted until the recent U.S. led war in Iraq. 
In 2002, the Security Council adopted resolution 1409, which introduced a list called the Goods Review List (GRL) that amounted to over 400 pages. This was established to implement a "new set of procedures for the processing and approval of contracts for civilian supplies and equipment" (Bahdi, 2002: 239). This made certain fundamental changes to what had been set in resolution 986 and causing further hindrance to the delivery of aid to Iraq.

Resolution 986 required that the Office of the Iraq Program in New York monitor any goods entering Iraq "which usually circulated the request to the Security Council's sanctions committee for consideration" (Ibid: 239). However, under the new procedures in resolution 1409, contracts for humanitarian supplies that were approved under the GRL were the ones sent to the Sanctions committee. In return, the Sanctions committee was authorized to veto any items it deemed to be used for military use and hence delaying the aid/relief process for further approvals and discussions (Ibid: 240). The idea was to initiate 'smarter' sanctions "thereby confirming that sanctions against Iraq during the previous 12 years had indiscriminately punished the Iraqi population as a whole" (von Sponeck, 2002)

The Security Council revised the Goods Review List in December 2002 under Resolution 1454. The resolution expanded the GRL to add items that Iraq was prohibited to export. This is to maintain control over items that may be used for military purposes by the Iraqi government. These goods that were added on the GRL included “medical auto injectors, guidance equipment and specified medicines with particular value in chemical and biological warfare applications" (Resolution 1454 - www.un.org accessed on May. $13^{\text {th }}$ 2006). 
The U.S. and the U.K. were convinced that Iraq possessed weapons of mass destruction in violation of Resolution 1441 and the only method of disarming Iraq was by force. On March $19^{\text {th }}, 2003$, Coalition forces began their military operations in Iraq and as a result, the OFFP distribution was suspended. On March $28^{\text {th }}$, the UNSC passed Resolution 1472, which allowed the UN to administer the OFFP for another 45 days and gave "the Secretary-General authority to facilitate the delivery and receipt of goods contracted by the Government of Iraq for the humanitarian needs of its people" (http://www.un.org accessed on July $22^{\text {nd }} 2006$ ).

In May 2003, the Security Council adopted Resolution 1483, which called for the removal of all UN monitors from Iraq. It eliminated the Oil for Food program along with the Sanctions Committee. Furthermore, the resolution transfers the responsibility of any remaining activity to the occupying powers (U.S. and U.K.) confirming their authority over Iraq.

\section{VII: Humanitarian Consequences of Sanctions and the Oil for Food}

\section{Program}

\section{I: Food, Health and Nutrition in Iraq}

The blockade had immediate effects on the food availability in the country. Iraq used to import $70 \%-80 \%$ of its food. The blockade caused food shortages, which in return resulted in intense increases in food prices ranging from 200\% to $1800 \%$ between August and November 1990 (Provost, 1992: 584-586).

A WHO/UNICEF mission to Baghdad in February 1991 estimated that the daily per capita calorie intake "had fallen (from the pre-sanctions level of 3340 kilocalories) to 
less than 1000 kilocalories (one third of the WHO recommendation)" (Simons, 1998:137). Four months later ${ }^{12}$, UNICEF reported severe malnutrition among children under the age of five.

The Oil for Food Program initially was intended for six months; however, at the end of each six-month period, it was renewed, as its goals were never met at the end of the first 6-month period. In May 1996, the Memorandum of Understanding under the Oil for Food Program between the UN Security Council and the Iraqi government allowed "Iraq to sell two billion (U.S.) dollars worth of oil over a 180-day period to buy humanitarian and food supplies" (UNICEF, 1998:18).

The allocation of the $\$ 2$ billion Oil for Food revenues between 1991-1999 were divided as follows:

$40 \%$ ( $\$ 600$ million) was for payment by Iraq as Gulf War reparations; $13 \%$ ( $\$ 260$ million) for the three autonomous governorates of the North, $2.2 \%$ for UN operational costs ( $\$ 44$ million) and $1 \%$ (\$20 million) for payments to escrow account. The remaining 53\% ( $\$ 1060$ million) of the oil revenues allowed Iraq to purchase humanitarian supplies for the South/Centre, with a population of over 18 million. The allocations per sector for Iraq by percent were as follows: food and detergent $(68.6 \%)$; health, mainly medicines $(16.7 \%)$, electricity and energy $(4.5 \%)$; agriculture and water/sanitation (each 3.3\%); education (2.1\%); resettlement $(0.9 \%)$; nutrition $(0.4 \%)$ and de-mining $(0.2 \%)$ (UNICEF, 1998).

The first oil under the Oil for Food Program was exported in December 1996.

Even though, oil exports commenced at the end of 1996, deliveries of food and medicines did not actually take place until half way into 1997. Decisions and approvals that were

12 Other missions under the UN Food and Agriculture Organization visited Iraq in 1993, 1995 and 1997 to "assess the crop and food availability situation and to investigate the nutritional status of the population in light of the ongoing sanctions" (Pellett, 2000:154). All of these reports showed declines in nutrition, food availability and major increases in malnutrition. 
dealt with by the UN sanctions committee in New York were enormously complex bureaucratic procedures that caused these delays and problems in food deliveries.

It was shown that "from 1997 until May of 2002, the total value of all food, medicines, education, sanitation, agricultural and infrastructure supplies that have arrived in Iraq had amounted to $\$ 175$ per person a year, or less than 49 cents a day" (von Sponeck, Globe and Mail 2002). By putting things into numerical perspective, one becomes more aware and understanding of the devastating effects that the Oil for Food Program (intentionally or not) caused.

VII. II: Child Malnutrition ${ }^{13}$

In northern Iraq, the under 5-mortality rate rose from 80 deaths per 1000 live births to 90 deaths per 1000 live births in the period between 1984-1989. However, between 1994-1999, under 5 mortality rates fell to 72 deaths per 1000 live births (www.unicef.org accessed on May. $13^{\text {th }}$ 2006). In the south/central region, however, the situation was drastic. UNICEF surveys indicated that between 1994-1999 under five mortality rates more than doubled from 56 deaths to 131 causing up to half a million deaths. These 1999 statistics of under 5 mortality rates were comparable to rates in Haiti (132) (Ibid), which were two of the world's poorest countries at the time. Below are statistics that show children's health deteriorating as economic sanctions progress.

- "Infant mortality in 2004 (107 deaths per 1,000 live births) is more than double what it was at the end of the 1980s. The under-five

${ }^{13}$ Garfield stated that, "The risk of dying increased dramatically" in infants 0-12 months between August - December of 1990. Sanctions consequences had already shown even before the 1991 Desert Storm had even started (Garfield, 2000: 546-52). 
mortality rate (131 deaths per 1,000 live births) is two-and-a-half times what it was in $1989^{14}$,

- "The water supply system was heavily compromised during the 1990 s. Restoration work was underway but children and women were still exposed to water-related health hazards on a daily basis. Safe drinking water is a nation-wide problem and cases of diarrhea have increased from an average of 3.8 episodes per child/year in 1990 to nearly 15 episodes by 1996. During the same period, typhoid fever increased from 2,240 to over 27,000 cases,

- "Preventable illnesses such as diarrhea and respiratory infections accounted for 70 per cent of child deaths" (www.unicef.org, 2004 accessed on May. $13^{\text {th }}$ 2006).

- "Levels of under-5 mortality in 1999 between girls and boys revealed that girls had a slightly lower rate, 125 deaths per 1000 live births as opposed to 136 deaths per 1000 live births among boys,

- "Children who live in rural areas had a higher mortality rate than children living in an urban area: 145 deaths per 1000 live births as opposed to 121 deaths per 1000 live births" (http://www.unicef.org accessed on May. 13th 2006)

- "There had been a dramatic increase in childhood cancers, particularly leukemia, Hodgkin's disease, and lymphomas,

\footnotetext{
${ }^{14}$ UNICEF estimated that there were 500,000 'excess' deaths per month in children under 5. This occurred above expected levels between 1991 and 1998 (Zurbrigg, 2003:10).
} 
- "Congenital diseases and deformities in the fetuses (a condition similar to the babies of the Gulf War veterans) had increased" (Masri, 1997 http://www.ibiblio.org/prism/Mar97/iraq.html accessed on May. 13th 2006).

The table below demonstrates the decline in mortality rates of children under the age of 5 during the $60 \mathrm{~s}$ and $70 \mathrm{~s}$ and the appalling increase during sanctions in the $90 \mathrm{~s}$.

\begin{tabular}{|c|c|c|}
\hline Year & Under 5 Mortality Rate & $\begin{array}{c}\text { Under One Infant } \\
\text { Mortality }\end{array}$ \\
\hline 1960 & 171 & 117 \\
\hline 1970 & 127 & 90 \\
\hline 1980 & 83 & 63 \\
\hline 1990 & 50 & 40 \\
\hline 1995 & 117 & 103 \\
\hline 1998 & 125 & \\
\hline
\end{tabular}

Source: (UNICEF quoted by Pellett, 2000:161)

In 2000, the Security Council appointed a panel that discussed the humanitarian crises that was taking place in Iraq. There was a major concern for the predicament of the Iraqi children more specifically. In summary, this is what the panel reported back to the Security Council.

In marked contrast to the prevailing situation prior to the events of 19901991 , the infant mortality rates in Iraq today are among the highest in the world, low infant birth weight affects at least 23 percent of all births, chronic malnutrition affects every fourth child under 5 years of age, only 41 percent of the population have regular access to clean water, 83 percent of all schools need substantial repairs. The ICRC states that the Iraqi health care system is today in a decrepit state. UNDP calculates that it 
would take 7 billion U.S. dollars to rehabilitate the power sector countrywide to its 1990 capacity (Bossuyt, 2000:17).

In 2002, a new survey report by UNICEF indicated that severe acute malnutrition dropped from 11 percent in 1996 to 4 percent in 2002. This may show somewhat of an improvement in children's health, however, "there are still close to one million children under the age of five suffering from chronic malnutrition in Iraq today (2002) - that's nearly a quarter of all children of that age," said Mr. Carel de Rooy, the head of UNICEF in Iraq (http://www.unicef.org accessed on May. 13th 2006).

\section{III: Impact of Sanctions on Women}

Younger and older Iraqi women had suffered the most along with children under these comprehensive sanctions. In 2002 , the "maternal mortality rate per 100, 000 live births had increased from 160 to 294 , making it the leading cause of death among Iraqi women of child bearing age" (Bahdi, 2002:3-4). The staggering decline of the economy had affected women greatly as they lost their jobs and stopped pursuing further education. Parents withdrew their children from the education system, more specifically girls to help support the family (Zurbrigg, 2003: 11). Furthermore, "early marriage has resurfaced in rural parts of Iraq as teenage girls are married off to reduce the number of mouths a family must feed" (Bahdi, 2002: 3-4). It is quite apparent that economic sanctions had shown the most detrimental impact on Iraqi women and children. As it is always the case that women and children are the most susceptible to violence and danger in any kind of conflict, and in this case, under a silent war. 


\section{IV: Environmental consequences}

More than 1 million rounds of weapons carrying Depleted Uranium ("DU”) were used against Iraqi troops during the Gulf War (Ammash, 2000:169). A terrifying total of “250 to 320 tons of DU were fired, including 14, 000 large Caliber (105 and $120 \mathrm{~mm}$ ) and 940, 000 small Caliber (25 and $30 \mathrm{~mm}$ ) bullets" (Ammash, 1997: 110). As much as 300 tons of expended DU ammunition remained scattered throughout Iraq and Kuwait (Ibid: 115). Moreover, the amount of explosives $(88,000$ tons) dropped on Iraq alone on the first day of air and naval attacks were equivalent to the explosive power of seven Hiroshima sizes atomic bombs (www.iraqaction.org accessed on May. $13^{\text {th }} 2006$ )

The first evidence found by Iraqi researchers that DU was used in the first U.S. led war on Iraq was in 1993 when they analyzed an Iraqi tank that was destroyed by a DU bullet in the battlefield in the south of Iraq. When researchers measured the radioactivity of DU that sat inside and outside the destroyed tanks, they registered levels of 84 microroentgen per hour, twelve times the natural background of 7.1 to 7.9 per hour (Marouf, 1998:130). These increases were associated with high concentrations of low percentage depleted U-235 that proved beyond a doubt the definite existence of DU contamination to the environment in and surrounding southern Iraq.

The accumulation of solid home wastes and water swamps created a suitable media for the growth of microbes, insects and rodents that had contributed to the spread of infectious diseases. Military bombardment altered the physical conditions of the surface soil, consequently affecting the seed bank by reducing "the density and composition of the plant life in Iraq" (Ammash, 2000: 170-175). The contamination of soil with "DU and heavy metals that make up DU such as vanadium, and nickel have 
reduced aeration, hindering seed germination, pollination and fertilization" (Ammash, 2000: 173).

The contamination of food with $\mathrm{DU}^{15}$ had caused severe health problems throughout the country. In the south of Iraq, cancer related deaths had increased significantly among adults and especially among children under the age of 5. Adults and children were also dying from the spread of infectious diseases due to immunedeficiencies and the closure of wastewater treatment units.

Many of the symptoms that had been detected were not just among civilians but also among many Iraqi veterans and Gulf War veterans. These symptoms included: leukemia, lung and bone cancer, depletion of the body's immune system, pulmonary and lymph node fibrosis, genetic defects, hepatic dysfunction, cardiovascular diseases and severe malnutrition.

Until 2000, sanitation and water systems remained critical as spare parts for equipment and machinery could not be purchased due to the sanctions' committee disapproval of such items. Furthermore, sanitation problems and water logging "contributed immensely to the rise of infectious diseases, such as hepatitis, typhoid fever and gastroenteritis" (Pellett, 2000:160).

\section{V: No Fly Zones}

In August 1991, No Fly Zones were established in the South of Iraq by the U.S., U.K. and France supposedly to protect northern Kurds and southern Shiites Muslims.

${ }^{15}$ The use of DU has never been officially investigated despite calls for an investigation. Dr Keith Baverstock, a senior radiation advisor with the WHO has gathered a study by three leading scientists on DU weapons being kept secret by the U.S. and the U.K.. He alleges that these reports have been suppressed. The reports show evidence that children and adults could contract cancer after inhaling DU in dust. It also shows that DU causes more damage in human cells than any other radioactive weapons (www.sundayherald.com). 
These countries validated their attacks by referring to resolution 688 , "which requested the UN General Secretary to address urgently the critical needs of the refugees and displaced Iraqi population" (von Sponeck, 2006:21) and even though there are UN Resolutions that call for the protection and the distribution of humanitarian relief to the Iraqi minorities, there are no outlined conditions for military enforcement in the Zones. Furthermore, the U.S. continued its bombing in the name of protecting the Kurds by preventing Saddam Hussein's government from using any military aircraft from attacking the minorities in the zones, yet when Turkey flew over the Iraqi No Fly Zone areas to bomb the Kurdish communities, the U.S. remained silent (Rothschild as quoted by Arnove 2000:73).

France withdrew from policing the No Fly Zone, but the U.S. and the U.K. continued their military operations (naval bases and ships). The main events were on January $17^{\text {th }}$ (42 cruise missiles), June $26^{\text {th }}$ (23 cruise missiles), 1996 Operation Desert Strike (44 cruise missiles) and December 16-19 Operation Desert Fox (hundreds of strike aircraft and cruise missiles)

(http://www.globalpolicy.org/security/issues/iraq/flyindex.htm accessed on Feb. $15^{\text {th }}$ 2006). There were further military deployments that were only intended to threaten Iraq, which included: the U.S. operations Phoenix Scorpion I, II, III and IV and Phases of Operation Desert Thunder lasting from November 1997 to December 1998 (Ibid: accessed on Feb. 15 2006 ).

By the end of 1999, the U.S. and the U.K. "had flown more than 6, 000 sorties, dropped more than 1800 bombs, and hit more than 450 targets" (Arnove, 2000:9). These attacks did not just target and threaten civilian infrastructure, they further resulted in 
massive civilian causalities and threatened the lives of many UN workers. Even though the intention may have been a positive one on behalf of the U.S. and the U.K., it is quite clear that civilian infrastructure and civilian casualties took place, showing that it only perpetuated fear over safety "as a result of an average of 3 air strikes per week" (von Sponeck, 2006: 22).

\section{VIII: Conclusion}

Sanctions represent a forceful measure of pressure. The perception of economic sanctions as a peaceful tool of coercion does not reflect the results of the fierce reality of the social devastation of the sanctioned society. In the African cases of Sierra Leone, Angola and Rwanda, UN arms embargoes have not just proven to be useless, but preposterous as their use as a response to the famine, war and genocide crises proved to be inadequate. In the cases of Iraq, Haiti and Yugoslavia, the use of sanctions failed miserably as humanitarian consequences far exceeded economic and political objectives of sanctions enforcement. Furthermore, the launch of military use in the latter cases only perpetuated social and economic problems.

Even in the South African case, economic sanctions definitely hurt the economy, however, the sports boycott under cultural sanctions had shown to be a success in satisfying socio-economic and political objectives of the internal anti apartheid movement. This shows that there are types of sanctions that need to be studied carefully and more effort needs to be deployed to investigate economic sanctions policies further. Comprehensive economic sanctions in Iraq failed as civilians were used as fulcrums to put pressure on the government. The Iraqi sanctions continued to target the innocent rather than topple the government. 
It is quite evident in the case of Iraq that the sanctions regime had shown reality obscured by sheer enormous complexity and inherent political pressures to understate the nature of political policies and its inhumane consequences. The crucial phases of the economic sanctions have only contributed to continuous infliction of pain and suffering on the Iraqi people that had yet to end. Resolution 986 that seemed as the solution to the Iraqi people was only a mask that was never intended to help mitigate the hardship (von Sponeck, 2006) ${ }^{16}$.

The system of sanctions on Iraq "turned economic policy into a one dimensional exercise determined by how much oil is produced, with the rest of the economy administered by the UN bureaucrats and arms inspectors" (AlNasrawi, 2001:218). Intention of an immediate humanitarian response to the disaster that was taking place in Iraq never seemed a priority. A further indication of this was the UN Secretary General's comments in 1995, stating that "resolution 986 was never intended to meet all the humanitarian needs of Iraqi people" (El- Bayoumi, 2000: 26-28).

Looking at the different phases of sanctions and the history of the deterioration of a people and a society, how can sanctions on Iraq be justified? Given the scale of the destruction in Iraq, the prospects for economic growth and recuperation were futile. Moreover, complete reliance on the oil sector alone was no longer an effective solution or an alternative to the crisis in Iraq. The Oil for Food Program continued the suffering of a people rather than reversing the outcome.

\footnotetext{
${ }^{16}$ See footnote 1 in chapter one.
} 
Dennis Halliday, the former United Nations Assistant Secretary-General and Humanitarian Coordinator in Iraq commenting on the social impact of economic sanctions on the Iraqi people, stated;

Sanctions have had a serious impact on the Iraqi extended family system. We are seeing an increase in single parent families, usually mothers struggling alone. There is an increase in divorce. Many families have had to sell their homes, furniture and other possessions to put food on the table, resulting in homelessness. Many people are resorting to prostitution (www.cam.ac.U.K. accessed on May. 13th 2006).

Sanctions placed a stranglehold on Iraqi civilians and the oil for food program was anything but adequate. Sanctions rendered destitute an entire population, destroying a civilian population and economic livelihood. By what means are economic sanctions a non-violent and benign alternative to war? With 5, 000 children dead per month for 14 years, are sanctions a continuation of economic terror? What does a program such as the Oil for Food accomplish under the name of humanitarian aid and humanitarian relief?

Comprehensive economic sanctions on Iraq did not just disrupt the economy by depriving Iraqis of sustainable livelihood; they had inflicted pain on Iraqi civilians by hurting the essential necessities of life such as health, food, the economy and education. Sanctions continued to target the powerless leaving the poor to become poorer and the rich untouched.

The next Chapter will discuss the relevance of international humanitarian and human rights law in the social devastation of the Iraqi people. International conventions that codify humanitarian and human rights law, and the role of the United Nations will be highlighted. The Chapter explores the contradictions between law in theory and law in 
practice to explore whether the "truth" behind the enforcement of human rights norms is a winning priority or is imposing a hegemonic political agenda. 


\section{Chapter III: The Legal Constraints of the Oil for Food Program}

\section{I: Introduction}

A sanctions regime "imposed during a war or as a consequence of war is governed by humanitarian law" (Bossuyt, 2000: 10). Under international humanitarian law (IHL), the essential needs and survival of the civilian population must be ensured. In the case of Iraq, the UN imposed a comprehensive sanctions regime as a response to the Iraqi invasion of Kuwait in 1990. With the continuous reinforcement of these comprehensive sanctions, the consequences that followed as shown in the previous Chapter, were severely punitive on the Iraqi civilian population.

In an international/humanitarian effort to alleviate the plight of the Iraqi people, the UN Security Council established the humanitarian program - Oil For Food. As a humanitarian/aid program, it was crafted in accordance with international humanitarian and human rights law and as "humanitarian law is like human rights law, considered ius/jus cogens ${ }^{17}$, sanctions in contravention of humanitarian law are void" (Ibid: 28 ). This Chapter focuses on the legal constraints of the Oil for Food Program, and the

\footnotetext{
${ }^{17}$ Article 53 of the Vienna Convention on the Law of Treaties 1969 provides for ius/jus cogens norm in international law. According to the Convention:

A treaty is void if, at the time of its conclusion, it conflicts with a peremptory norm of general international law. For the purposes of the present Convention, a peremptory norm of general international law is a norm accepted and recognized by the international community of States as a whole as a norm from which no derogation is permitted and which can be modified only be a subsequent norm of general international law having the same character (Article 53 as quoted by Malanczuk., 1997: 57).

Ius cogens is known as the "peremptory norms of general international law" (Malanczuk, Ibid). They are primary and basic rules of customary international law that are essential and cannot be abandoned or set aside by a treaty. Common examples of ius cogens include genocide, prohibitions of slavery as well as the use of force by States.
} 
violations of its basic legal premises under international humanitarian and human rights law that occurred from its administration and manipulation.

I will begin by giving a background to international humanitarian law with a particular focus on two core principles: distinction and proportionality. Following this, the role of ius cogens and the concept of Martens Clause and its function during economic sanctions will be described to illustrate the predicament and failure of the Oil for Food Program as a humanitarian program. I will then move on to discuss the limitations and violations that had been incurred by the Security Council in the case of the Oil for Food Program under international human rights law. Provisions under the legally binding conventions such as the International Covenant on Civil and Political Rights (ICCPR) and the International Covenant on Economic, Social and Cultural Rights (ICESC) both of 1966, the Convention on the Elimination of Discrimination Against Women (CEDAW) (1979) and the UN Charter (1945) along with the non-binding instrument, the Universal Declaration of Human Rights (1948) will be used as examples that show serious violations and limitations posed by the permanent members of the Security Council during the imposition of economic sanctions against Iraq and under the implementation of the Oil for Food "humanitarian" Program.

\section{II: International Humanitarian Law}

International humanitarian law is "a set of international rules, established by treaty or custom, which are specifically included to solve humanitarian problems directly arising from international or non international armed conflicts" (ICRC, 2003: 1), also known as the laws of war. International humanitarian law's main purpose "is to enable civilians to remain at home, thereby ensuring that their basic needs are met, including 
those related to food" (Pejic, 2001: 1100). Furthermore, it seeks to resolve matters of humanitarian concern and protects civilians who do not take part in the armed conflict.

International humanitarian law is applicable in two situations: international armed conflict and non-international armed conflict. International armed conflicts are "wars involving two or more states, and wars of liberation, regardless of whether a declaration of war has been made or whether the parties involved recognize that there is a state of war" (ICRC, 2003:1). Under an international armed conflict, the treaty sources applicable "are the four Geneva Conventions of 1949 and their Additional Protocol I of 1977" (Ibid). Non-international armed conflicts are "government forces fighting against armed insurgents, or rebel groups fighting amongst themselves" (Ibid). The treaty sources applicable under these conflicts are "article 3 common to the Geneva Conventions and Additional Protocol II of 1977" (Ibid). International humanitarian law forces parties to differentiate between the civilian population and combatants and engage in limited methods of warfare.

There are several principles of international humanitarian law, the two core ones of relevance to this research paper are: distinction and proportionality. The principle of distinction means that aggressors are required to distinguish between civilians and combatants at all times (United Nations General Assembly Resolution 2444 of 1968). It imposes the rule that targeting of civilians and civilian infrastructure is unlawful. This principle is conveyed in the Hague treaty IV (respecting the Laws and Customs of War on Land and its annex: Regulations concerning the Laws and Customs of War on Land under Means of Injuring the Enemy, Sieges and Bombardments), Article 25, "which prohibits the attack or bombardment, by whatever means, of towns, villages, dwellings or 
buildings which are undefended is prohibited." The principle of proportionality implies that before an attack, there must be an examination of the humanitarian problems expected to be caused by the attack. Hence, an "attack which may be expected to cause incidental loss of civilian life, injury to civilians, damage to civilian objects... which would be excessive in relation to the concrete and direct military advantage anticipated" (Protocol I, Article 57, 2a iii) is considered unlawful. In the case of Iraq, the imposition of comprehensive economic sanctions has targeted an entire population as shown in the previous chapter causing not just an economic collapse but also an enormous humanitarian disaster.

It is important to note that international humanitarian law's provisions are considered non-derogable as it deals with emergency situations. Norms that are nonderogable are recognized as ius cogens and these standards apply to the Security Council enforcement measures taken under Chapter VII of the UN Charter (Gill, 1995: 79). These laws bind all actors involved, States and non-State actors.

\section{III: International Humanitarian Law During Economic Sanctions}

Beyond the UN Charter, the laws of war - jus ad bellum and jus in bello - apply to the use of economic sanctions according to the International Institute of Humanitarian Law. It is maintained that "that any sanctions policy must be measured against the normative rules of jus belli because a sanctions policy is 'de facto constitutive of a war strategy"' (Kochler quoted by Cosgrove, 1999: 71). Even though this argument is problematic, it is nonetheless worth making as the same laws that apply to an armed conflict, apply to economic sanctions. 
During the imposition of economic sanctions in an armed conflict, whether international or not, international humanitarian law and human rights law remain nonderogable provisions that complement one another and must be followed. Sanctions "which invalidate the fundamental economic and social rights of the population (and in many cases even the right to life) are - in view of human rights as the jus cogens of international law - impermissible" (Köchler, 1994: 12). The authority of Chapter VII of the UN Charter does not allow the Security Council to override the concept of ius cogens. Furthermore, the Security Council must comply with Article 24 (2) of the Charter and abide by the Purposes and Principles of the United Nations when making its decisions (Gill, 1995: 33 - 138). In the event of an inconsistency between an IHL provision and UNSC Resolution, the non-derogable norms prevail and should the Security Council violate "fundamental (non-derogable) human rights or humanitarian law rules and principles which are binding upon the Council and its Members ${ }^{18 "}$ (Ibid: 131 - 138), this would constitute an illegal act as the Security Council cannot stand above the law when dealing with ius cogens of international law.

In the Preamble to the Second Hague Convention of 1899, a Martens Clause was created, and later incorporated into the First Additional Protocols to the Geneva Conventions in 1949. The Martens Clause "evokes the general humanitarian principles to which the Security Council is also bound by virtue of ius cogens during the implementation of its sanctions policy" (Köchler, 1994: 21). It further requires that the civilian population "remain under the protections and the rule of the principles of the law

\footnotetext{
${ }^{18}$ Article 1 (3) of the Charter is explicit in saying, " promoting respect for human rights and fundamental freedoms "for all without distinction"' (Köchler, 1994: 13).
} 
of nations, as they result from the usages established among civilized peoples, from the laws of humanity, and the dictates of the public conscience" (Köchler, 1994:21) at a time when provisions relating to the areas of the law of war are non existent. This "formulation clearly upholds human rights as the ius cogens of general international law. Thus, the humanitarian consequences of the provisions of the UN Charter - especially those in Chapter VII - must be constantly examined with regard to human rights" (Köchler, Ibid).

A prominent case that has upheld the notion of Martens Clause and affirmed that the principles and rules of international humanitarian law apply to the use of force and nuclear weapons in armed conflict is the 1996 Advisory Opinion requested by the UN General Assembly from the International Court of Justice. In the case Legality of the Threat or Use of Nuclear Weapons, the ICJ provided an authoritative judicial opinion by stating that:

(i) A threat or use of force by means of nuclear weapons that is contrary to Article 2, paragraph 4, of the United Nations Charter and that fails to meet all the requirements of Article 51, is unlawful;

(ii) A threat or use of nuclear weapons should also be compatible with the requirements of the international law applicable in armed conflict, particularly those of the principles and rules of international humanitarian law, as well as with specific obligations under treaties and other undertakings which expressly deal with nuclear weapons (http://www.icj-cij.org accessed on August 4th 2006).

In the case of sanctions against Iraq, it was the United Nations Security Council's responsibility to take into account the relevant rules that protect and promote the dignity of the civilian population. Furthermore, it must also provide for humanitarian exceptions 
to the severity of sanctions. Some of these rules are found in the Geneva Conventions and their protocols. They include:

\section{III: I: The right to humanitarian assistance:}

This right shows that civilians have the right to humanitarian assistance in times of armed conflict/emergency situations through provisions allowing humanitarian agencies to provide aid/assistance and by allowing the free passage of relief goods.

In international armed conflicts, the following rules apply:

(i) States shall allow the free passage of:

- medical and hospital consignments and objects necessary for religious worship intended only for civilian population; and

- essential foodstuffs, clothing and tonics intended for children under 15, expectant mothers and maternity case (Fourth Convention, Article 23).

(ii) The rule in paragraph (i) above has been extended by Additional Protocol I of 1977, which provides that humanitarian and impartial relief actions shall be undertaken, subject to the agreement of the parties concerned, if the civilian population is not adequately provided with clothing, bedding, means of shelter, other supplies necessary to their survival and objects necessary for religious worship (Protocol I, Article 70.1).

In 1997 , it was reported that " $30 \%$ of hospital beds were out of use, $75 \%$ of all hospital equipment did not work and $25 \%$ of Iraq's 1305 health centers were closed" (Bossuyt, 2000:17). This was all due to the lack of medical supplies and humanitarian assistance. Even under the Oil for Food Program as shown in the previous chapter, there were restrictions on the kind of assistance and supplies that could be delivered to Iraq.

In 1999, UNICEF concluded that in the heavily populated southern and central parts of the country, children under five are dying at more than twice the rate they were 10 years ago (Ibid: 17 , See Appendix VII). 
III. II: Relief supplies in naval blockades:

Civilians during naval blockades have the right to humanitarian assistance and the free passage of relief goods.

(i) Convoys of vehicles or hospital trains on land or specially provided vessels on sea, conveying wounded and sick civilians, the infirm and maternity cases, shall be respected and protected in the same manner as the hospitals provided for in Article 18 (Fourth Convention, Article 21).

(ii) States must allow the free passage of essential foodstuffs for children, expectant mothers and maternity cases and of medical goods and objects necessary for religious worship for the civilian population generally (Fourth Convention, Article 23).

(iii) Humanitarian and impartial relief actions shall be undertaken, subject to the agreement of the parties concerned (Protocol I, Article 70).

Despite the creation and implementation of the Oil for Food Program as a

humanitarian program under the sanctions regime, not enough food and calorie intake was being provided to the Iraqi population, as there was much hindrance in the free of passage of many relief goods. An expert on the effects of sanctions on civilians stated that:

The underlying causes of these excess deaths include contaminated water, lack of high quality foods, inadequate breastfeeding, poor weaning practices, and inadequate supplies in the curative health care system. The lack of food due to sanctions translated into a $32 \%$ drop in per capita calorie intake compared to before the Gulf war (Bossuyt, 2000:16).

III. III: Protection of objects indispensable to the survival of the civilian population

(Protocol I, Article 54):

Starvation of civilians is considered a war crime and should not be used as a tool of war as it violates international humanitarian law and human rights law. Furthermore, 
the attack and destruction of civilian infrastructure is illegal as it renders useless the sustenance of civilians' humanity and existence.

(i) Starvation of civilians as a method of warfare is prohibited

(ii) It is prohibited to attack, destroy, remove or render useless objects indispensable to the survival of the civilian population, such as food-stuffs, agricultural areas for the production of food-stuffs, crops, livestock, drinking water installations and supplies and irrigation works, for the specific purpose of denying them for their sustenance value to the civilian population or to the adverse Party, whatever the motive, whether in order to starve out civilians, to cause them to move away, or for any other motive (Protocol I, Article 54).

No Fly Zone areas were created by the U.S., U.K. and French governments as mentioned in the previous Chapter to carry out military operations. The French government withdrew leaving the U.S. and the U.K. responsible for its creation and the bombing of civilian infrastructure on a daily basis. During one of the operations, the bombings "resulted in 144 civilian deaths and 446 civilians injured as a result of an average of 3 air strikes per week" (von Sponeck, 2006: 17). In addition to the casualties, these No Fly Zones created a "siren syndrome" (Ibid: 17) whereby children and civilians became alert at all times and fearful of these continuous bombings (Ibid: 17). Furthermore, this hindered the Oil for Food Operations as "UN trucks had to observe curfew hours thus slowing down the distribution of food and other supplies. UN missions had to be off the road during times of expected air strikes" (Ibid: 17). III. IV: Protection of the Natural Environment (Protocol I, Article 55):

This provision prohibits the use of means of warfare that is intended to cause long term and widespread damage to the environment, hence affecting civilian health and survival. An example that can be easily and commonly used under this rule is the use of 
chemical weapons, which is also stipulated under the International Criminal Court Statute as a war crime under Article 8 (b) (iv) and 8 (b) (xx).

(i) Intentionally launching an attack in the knowledge that such attack will cause incidental loss of life or injury to civilians or damage to civilian objects or widespread, long-term and severe damage to the natural environment which would be clearly excessive in relation to the concrete and direct overall military advantage anticipated.

(ii) Employing weapons, projectiles and material and methods of warfare which are of a nature to cause superfluous injury or unnecessary suffering or which are inherently indiscriminate in violation of the international law of armed conflict, provided that such weapons, projectiles and material and methods of warfare are the subject of a comprehensive prohibition and are included in an annex to this Statute, by an amendment in accordance with the relevant provisions set forth in articles 121 and 123.

As shown in the previous chapter, the use of "weapons of mass destruction such as depleted uranium (DU) munitions constitute indicators of serious illegality on the part of U.S. authorities" (von Sponeck, 2006: 20). The massive destruction of the infrastructure produced major damages to the soil, food chain, the agriculture, electricity and water. With the enforcement and imposition of economic sanctions, it was difficult to clean up DU and the debate has been deflected by the Security Council "postponing the formal admission by perpetrators that DU is indeed the cause of ill health of Iraqis and members of the coalition forces and genetic damage among their off-spring" (ibid.). Furthermore, the inadequacy of the oil for food program rations to the public did not make up for the loss of soil and agriculture that has been under serious destruction by depleted uranium.

International humanitarian law and international human rights law complement one another in times of war and economic sanctions. Therefore, it is important to also 
discuss the rules of international human rights law that have been violated by the Security Council against Iraq in the case of sanctions and the Oil for Food Program.

\section{IV: International Human Rights Law}

International Human Rights law is "a set of international rules, established by treaty or custom, on the basis of which individuals and groups can expect and/or claim certain behaviour or benefits from governments" (ICRC, 2003:1). International human rights law is applicable at all times: in peace and armed conflicts. In some cases, "international human rights law treaties permit governments to derogate from certain rights in situations of public emergency" (Ibid: 1). However, some human rights are not

derogable such as, "the right to life, prohibition of torture or cruel, inhuman or degrading treatment or punishment, prohibition of slavery and servitude and the prohibition of retroactive criminal laws" (Ibid: 1 ).

The main treaty sources applicable under international human rights law are the "International Covenants on Civil and Political Rights, and on Economic Social and Cultural Rights (1966), as well as the Conventions on Genocide (1948), Racial Discrimination (1965), Discrimination Against Women (1979), Torture (1984), and Rights of the Child (1989)" (ibid: 1).

In the case of economic sanctions against Iraq and the Oil for Food Program, it can be argued that certain human rights should have been upheld to prevent the devastating effects of war and economic blockade on Iraqi civilians. These international human rights provisions and laws include: 


\section{I: Universal Declaration of Human Rights}

This Declaration is adopted by the General Assembly outlining the responsibility of the Organization in promoting and protecting human rights of all individuals in times of peace and war. Some of its provisions "constitute general principles of the law or represent elementary considerations of humanity" (Brownlie, 2003: 535). Even though the Declaration is a non-binding soft law, "it establishes binding value overtime as it creates an internationally recognized agenda of human rights standards binding on States irrespective of their membership of treaty regimes" (www.unesco.org accessed on July 30, 2006). The Declaration has been frequently referred to as part of the "law of the United Nations" (Brownlie, 2003: 535) and has been "invoked by the European Court of Human Rights, as an aid to interpretation of the European Convention of Human Rights" (Ibid: 535). The important provisions that are adequate and essential to observe in times of sanctions, especially those against Iraq are the following:

(i) Everyone has the right to life, liberty and security of person (Article 3)

(ii) No one shall be subjected to torture or to cruel, inhuman or degrading treatment or punishment (Article 5)

(iii) Everyone has the right to a standard of living adequate for the health and well-being of himself and of his family, including food, clothing, housing and medical care and necessary social services, and the right to security in the event of unemployment, sickness, disability, widowhood, old age or other lack of livelihood in circumstances beyond his control (Article 25-Para 1)

(iv) Motherhood and childhood are entitled to special care and assistance. All children, whether born in or out of wedlock, shall enjoy the same social protection (Article 25-Para 2).

As shown above and in the previous Chapter, the Oil for Food Program had severe inadequacies in providing proper and sufficient relief and/or assistance to children and pregnant mothers. Article 3 especially has been greatly violated as the security of 
Iraqi women, men and children has been severely infringed upon by the continuous bombing in the No Fly zone areas, the "siren syndrome" and the lack of food stuffs and aid under the oil for food program.

\section{II: Charter of the United Nations}

It is of great importance to note that the "right to impose sanctions is not unlimited" (Bossuyt, 2000: 7) and that there is a limit to the amount of suffering that sanctions may cause. As stated in Article 39 of the Charter:

The Security Council shall determine the existence of any threat to the peace, breach of the peace, or act of aggression and shall make recommendations, or decide what measures shall be taken in accordance with Articles 41 and 42, to maintain or restore international peace and security (Article 39).

This would follow that only in times of maintaining and restoring international peace that sanctions should be imposed, which was the case when Iraq attacked Kuwait in 1990. However, another limitation to the imposition of sanctions as mentioned by Judge Bossuyt is that the "threat may not be determined on the basis of ulterior political motives - there must be a genuine international concern behind the sanctions, not the foreign or domestic policy considerations of a single State or group of States" (Bossuyt, 2000: 7). In the case of Iraq, the excuse was that it was capable of producing weapons of mass destruction, when in fact Scott Ritter, former Chief Weapons Inspector for the UN Special Commission in Iraq, in an address to the Iraqi parliament said, "the rhetoric of fear that is disseminated by my government and others has not to date (2002) been backed up by hard facts that substantiate any allegations that Iraq is today (2002) in possession of weapons of mass destruction or has links to terror groups responsible for 
attacking the United States. Void of such facts, all we have is speculation" (U.S.

Department of State - http://www.state.gov.html accessed on May. 15 $5^{\text {th }} 2006$ ).

This clearly shows that there was no proof that Iraq possessed weapons of mass destruction to support such prolonged and comprehensive sanctions. It further shows the hegemonic role that the U.S. continues to have over Iraq for its own vested political and economic interests as explained in Chapter One.

There are further provisions that coincide and complement with those mentioned above; they are:

(i) To achieve international co-operation in solving international problems of an economic, social, cultural, or humanitarian character, and in promoting and encouraging respect for human rights and for fundamental freedoms for all without distinction as to race, sex, language, or religion (Article 1, Para 3)

(ii) Higher standards of living, full employment, and conditions of economic and social progress and development (Article 55, Para 1).

(iii) Solutions of international economic, social, health, and related problems; and international cultural and educational cooperation (Article 55, Para 2).

(iv) All Members pledge themselves to take joint and separate action in co-operation with the Organization for the achievement of the purposes set forth in Article 55 (Article 56).

\section{III: International Covenant on Economic, Social and Cultural Rights}

In the ICESCR, States must recognize that "the ideal of free human beings enjoying freedom from fear and want can only be achieved if conditions are created whereby everyone may enjoy his economic, social and cultural rights, as well as his civil and political rights" (Kozal, 2000: 395). Certainly, Iraqis have not been able to enjoy any of these rights during the imposition of sanctions and the implementation of the Oil for Food Program. The “United Nation's Department of Humanitarian Affairs estimated 
about 4 million Iraqis live in extreme poverty. The purchasing power of the Iraqi Dinar (ID) reduced from U.S. \$3 = 1 Iraqi Dinar in 1990 to about U.S. \$1 = ID 1,500 in 1997. The GDP per capita has decreased from $\$ 3500$ to $\$ 600$; public workers average salaries are about $\$ 3$ to $\$ 5$ per month, compared to $\$ 50-100$ prior to $1990 "$ (Kozal, 2000: 395 396). Such illegalities can be seen in the ICESCR under the following provisions:

(i) The States Parties to the present Covenant recognize the right of everyone to an adequate standard of living for himself and his family, including adequate food, clothing and housing, and to the continuous improvement of living conditions. The States Parties will take appropriate steps to ensure the realization of this right, recognizing to this effect the essential importance of international cooperation based on free consent (Article 11, Para 1).

(ii) The States Parties to the present Covenant, recognizing the fundamental right of everyone to be free from hunger, shall take, individually and through international co-operation, the measures, including specific programmes, which are needed (Article 11, Para 2)

(a) To improve methods of production, conservation and distribution of food by making full use of technical and scientific knowledge, by disseminating knowledge of the principles of nutrition and by developing or reforming agrarian systems in such a way as to achieve the most efficient development and utilization of natural resources (Article 11, Para 2a)

(b) Taking into account the problems of both food-importing and food-exporting countries, to ensure an equitable distribution of world food supplies in relation to need (Article 11, Para 2b)

(iii) The States Parties to the present Covenant recognize the right of everyone to the enjoyment of the highest attainable standard of physical and mental health (Article 12, Para 1)

(iv) The steps to be taken by the States Parties to the present Covenant to achieve the full realization of this right shall include those necessary for (Article 12, Para 2): 
(a) The provision for the reduction of the stillbirth-rate and of infant mortality and for the healthy development of the child;

(b) The improvement of all aspects of environmental and industrial hygiene;

(c) The prevention, treatment and control of epidemic, endemic, occupational and other diseases;

(d) The creation of conditions, which would assure to all medical service and medical attention in the event of sickness.

The lack of foodstuffs and aid under the Oil for Food Program along with the sanctioning of health supplies such as insulin and anticancer supplies (See Appendix II) affected the lives of many Iraqi children. UNICEF surveys had shown that between 1994 to1999, there were excess deaths of 500,000 children (www.unicef.org/newsline/99pr29.htm accessed on May. 15th 2006). These numbers are preposterous as infant and child mortality was on the rise under sanctions and the oil for food program, violating basic rights of Iraqi children and hampering the survival of an entire future generation.

\section{IV: International Covenant on Civil and Political Rights}

The International Covenant on Civil and Political Rights (ICCPR) and the Convention on the Elimination of All Forms of Discrimination Against Women (CEDAW) offer protection against violation of citizens and women's civil and political rights. The provisions related to rights violated under economic sanctions are:

(i) Every human being has the inherent right to life. This right shall be protected by law. No one shall be arbitrarily deprived of his life (ICCPR, Article 6, Para 1a).

(ii) No derogation from articles $6,7,8$ (paragraphs I and 2), 11, 15, 16 and 18 may be made under this provision (ICCPR Article 4, Para 2).

(iii) Notwithstanding the provisions of paragraph I of this article, States Parties shall ensure to women appropriate services in connection with pregnancy, confinement and the post-natal period, 
granting free services where necessary, as well as adequate nutrition during pregnancy and lactation (CEDAW Article 12, Para 2).

(iv) To have access to adequate health care facilities, including information, counselling and services in family planning (CEDAW Article 14, Para 2b)

(v) To enjoy adequate living conditions, particularly in relation to housing, sanitation, electricity and water supply, transport and communications (CEDAW Article 14, Para $2 h$ ).

These two conventions along with the International Covenant on Economic,

Social and Cultural Rights are binding treaties under international human rights law that create obligations on states that sign and ratify them such as the U.S. and the U.K.

Conventions such as these must be taken into consideration by the Sanctions Committee and the UNSC when imposing sanctions. An important provision under the ICCPR is Article 4, which contains concepts dealing with the non-derogability of basic human rights.

\section{V: Conclusion}

There seems to be a compelling yet ludicrous argument that sanctions is a much civilized, enhanced and improved technique of diplomacy than war. President Woodrow Wilson once said that sanctions are a "peaceful, silent and deadly remedy" (Gordon, 1999: 123). This only proves to show that sanctions can be considered an indirect/silent war and in the case of Iraq, they have shown to prove just that. Economic sanctions against Iraq interrupted human nutrition, growth, production and resulted in much destruction, disease, economic prostration and death. The imposition of sanctions causes major contradictions in promoting and protecting human rights. In the case of Iraq, sanctions have proven to be indiscriminate as they affected a wide array of the Iraqi population. 
Since sanctions in the context of armed conflict are governed by international humanitarian law, it requires that the essential basic needs of the civilian population be ensured such as food, water and medical supplies. This was supposed to be fulfilled under the Oil for Food Program, which had failed miserably in providing the Iraqi population with any kind of relief or aid to rescue its unfortunate fate. The Program was nothing but a mask in disguise to end the outcry of the international community and maintain continuous hegemony of the U.S. and the U.K. over Iraq.

While both International humanitarian law and international human rights law complement one another in protecting basic human rights and human dignity in the midst of conflict, it has been shown in the case of Iraq that it is easily violated and skewed leaving innocent women, men and children to ailment, malnutrition and death. The Security Council failed to uphold essential concepts of international humanitarian law such as ius cogens and Martens Clause while enforcing sanctions against Iraq and while implementing the Oil for Food program. The Security Council must not be given unreserved authority, especially if it violates the most imperative norms of international law enshrined in the UN Charter. The Security Council must be overseen to ensure continuous alignment with binding instruments such as the ICCPR, ICESCR, CEDAW and the UN Charter. The Council has to recognize the essentiality of the Universal Declaration of Human Rights regardless of its nature as a non-binding soft law.

Since economic sanctions are considered the next instrument of diplomacy and will unlikely be abandoned, the next Chapter will focus on a set of recommendations on sanctions regime and humanitarian programs to ensure that they respect the basic norms of humanitarian and human rights law. The next Chapter draws from a recent 2006 
report by Hans von Sponeck that discusses the options that the Security Council could have used in the case of Iraq to alleviate the Iraqi civilians' pain but chose not to. 


\section{Conclusion: Recommendations for New Sanctions Policy}

Given that economic sanctions will not be abandoned and will continue to be part of the New World Order, how best could sanctions be more humane and effective in the international system? How best can the norms of international human rights and humanitarian law be built into a sanctions regime?

In the last three Chapters, I critically evaluated the notion of economic sanctions imposed on Iraq and "humanitarian" program implemented to address the humanitarian disaster caused by the sanctions. Chapter Two reviewed the history of economic sanctions with a more specific examination of the sanctions imposed on Iraq. I further evaluated the "humanitarian" Oil for Food Program.

Chapter three explored the violations of the norms of international human rights and humanitarian law such as ius cogens. Both soft and hard laws that codify international human rights and humanitarian laws are applicable during wars and economic sanctions. In the last two chapters, I argued that hegemonic powers such as the U.S. and the U.K. pursued their vested interests in violation of the basic human rights of the Iraqi people. In Iraq, economic sanctions have resulted in the obliteration of society's most important aspects of life such as the economy, health and public infrastructure. The Oil for Food Program was anything but a "true" humanitarian program that only continued the devaluation of people's health, nutrition and daily lives.

It is important at this point to begin a discussion on the importance of upholding international human rights and humanitarian law during times of armed conflict, peace and economic sanctions. It is important to focus on recommendations for new sanctions policy for the betterment of such a tool for future use. The discussion will begin with 
Hans Von Sponeck's report on the recommendations that he had passed on to the Security Council on sanctions against Iraq and was never followed through. Then, the discussion will continue with a general dialogue on recommendations for new sanctions policy and humanitarian programs during a sanctions regime.

\section{I: Hans von Sponeck's Recommendations (Case of Iraq):}

Hans von Sponeck, the former Coordinator of the Humanitarian Program (Oil-forFood) in Iraq from 1998 to 2000 recommended 22 "humane options" (See Appendix VIII) to the Security Council, which consists of alternatives on how the sanctions regime and the Oil for Food Program could have alleviated the humanitarian crisis in Iraq. The Security Council chose not to pursue these options, which "reveals elements of intent and therefore willful violation of international humanitarian law and other law" (von Sponeck 2006:1), some of them with relevance to this research paper are:

- "A more humane option would have been to appeal for international voluntary donations to be supplemented by contributions by member governments to make up any shortfalls of the funds needed. This would have been a responsible and human rights-minded approach on the part of the UN Security Council keeping in mind that socio-economic conditions were deteriorating because of the imposition of economic sanctions. Such an approach would have resulted in lower mortality, particularly among children, less malnourishment and better epidemiological condition,

- "A more humane option would have been based on a careful quantitative assessment of needs and a provision for regular integrated and holistic updates with guaranteed finance. This would have ensured that the impact of UN Security Council sanctions policies on the welfare of the Iraqi people would not have been punitive and been in accordance with international law,

- "A more humane option would have been to lessen economic sanctions incrementally in response to cooperation by the Government of Iraq or preferably in response to the evolving needs of the Iraqi people, 
- "A more humane option would have been to establish a red list ${ }^{19}$ approach from the very beginning of the oil-for-food programme. Consistent with international humanitarian law, a "no list" approach for food and medicines should have been an integral part of the regulatory framework. This would have allowed the inclusion in the food basket of fresh fruits, vegetables and meat and reduced the cost for food as locally purchased food items were significantly cheaper than imported ones. Such an approach would have freed resources for other sectors and helped to preserve life and livelihood,

- "A more humane option would have been to implement a clearly formulated sanctions strategy based on a pre-sanctions human condition profile of Iraq. Such a strategy would have had to be subject to continuous oversight by the Security Council and reinforced by an Iraq watch group at the UN Secretariat closely linked to the UN Humanitarian Coordinator in Baghdad. The main objective would have been to ensure that the required inputs would have been available at all times to meet the needs of the civilian population,

- "A more humane approach would have been to base the humanitarian exemption on a careful pre-sanctions assessment followed by continuously updated evaluations of the evolving conditions of a society living under economic sanctions,

- "A more humane option would have been to build into the oil-for-food programme in all parts of the country a cash component from the beginning. UN observers and audits could have verified, as they did in Iraqi Kurdistan, the appropriate use of these minor amounts of cash. The availability of cash would have removed one of the impediments in the humanitarian exemption and helped to preserve life and well-being,

- "A more humane option would have been for the UN Security Council to ensure that regular sanctions effectiveness tests were carried out by either the UN Sanctions Committee or the UN Secretariat in order to identify the impact of international policy on the human condition in Iraq. This would have allowed remedial actions for protection of the Iraqi people to take place and would have been in compliance with UN Charter and other international law,

- "A more humane option would have been to confine the air forces of the U.S. and U.K. to the Sultan and Incirlik Air Force Bases in central Saudi Arabia and south eastern Turkey. Such a policy would not have violated UN Charter law and facilitated the implementation of the oil-for-food programme. Fewer Iraqi

\footnotetext{
${ }^{19}$ Red List "was a negative list of items that were potentially of 'dual usee' or had other strategic value" (von Sponeck 2006:6). The green list identified items and goods that were allowed to be brought into Iraq under the Oil for Food Program without the inspection of the UN Sanctions Committee.
} 
civilians would have perished and many would have benefited more quickly from humanitarian supplies,

- "A more humane option would have been for the UN Security Council and the UN Secretariat to issue periodic reports of high quality to the international public that would reflect the actual humanitarian conditions in Iraq as reported by the UN system in Baghdad. Such factual information could have been used by groups and individuals to enhance pressure for improvements in international support for a people under sanctions and signal to the U.S. and U.K. governments that manipulation of facts was unethical, pointless and ultimately politically counterproductive" (von Sponeck 2006: 1 -21, See Appendix VIII)

The options mentioned above by Sponeck show the possibility for a better implementation of the sanctions regime in Iraq; however, with the continuous disregard by the Security Council, and more specifically the U.S. and the U.K., of these recommendations show a degree of intent and a violation of several international human rights and humanitarian laws. A relief basis in Iraq did not exist as needs assessments were not carried out and funding levels were never met. This drastically affected the effectiveness of the implementation of the Oil for Food Program. The damaged oil facilities of Iraq were considered dangerous yet nothing was done in order to repair them. Iraqi civilians' basic needs depended on the production of oil and with its weak infrastructure and its rapid fluctuation; Iraqis lives were not changing for the better.

The amount that was allocated for the education sector under the Oil for Food Program was lower than was expected. There was a willful destruction of the future generation of Iraqi youths as the educational system was destroyed. The "U.S. and the U.K. governments intensified the problem by adding harsh bilateral measures in an effort to prevent educational material from reaching Iraq" (Ibid: 5). International donations in this context would have helped immensely in constructing and renovating schools and supplying educational supplies for the education system to develop, flourish and evolve. 
In the case of monitoring educational supplies and all other items, UN officials on the ground should have been in charge of the monitoring and distribution of all items in Iraq. This would have alleviated much suffering and pain on the Iraqi population.

Under the Oil for Food program, a "red list" was replaced by a "green" list, which in essence did not make delivery of goods easier as "the U.S. and U.K. representatives in the UN Sanctions Committee increased the volume of items that were permanently or temporarily blocked from delivery to Iraq" (von Sponeck, 2006: 6). There should have been different lists made for essential and necessary goods and items, as they should never be blocked in times of sanctions, especially comprehensive sanctions.

The notion of comprehensive economic sanctions must be abandoned and differentiated from partial sanctions. Comprehensive sanctions "make the civilian population the hostage of the Security Council, of the state, or of the group of states implementing the coercive measures" (Köchler, 1995: 20) leaving an entire population such as the Iraqi population under utter scrutiny and pain. The Security Council must consider targeted/selected sanctions, such as financial, diplomatic and/or travel.

A human rights group should have been integrated under the umbrella of the UN Sanctions Committee to provide continuous monitoring of the sanctions regime in Iraq and to assure that the Sanctions Committee and the Security Council are adhering with international human rights and humanitarian law. The No Fly Zone areas are only one example of many continuous violations of international human rights law in Iraq. Furthermore, comprehensive economic sanctions, which heavily impact the life of an entire civilian population, need to be critically evaluated and examined from an ethical point of view. 


\section{II: Alternatives and Recommendations For a New Sanctions Policy}

This thesis has argued that comprehensive economic sanctions can be enormously harmful. In the case of Iraq, it is arguable that it served as a weapon of mass destruction. The first step that must be taken towards a new sanctions policy is the abandonment of comprehensive economic sanctions as a whole. Comprehensive sanctions will only be useful if they harm the civilian population. Unless the civilian pain is passed on to the targeted government, which will have to oblige with conditions for lifting sanctions, comprehensive sanctions will never act as a substitute to war but a weapon of war. I am not suggesting abandoning the instrument of economic sanctions; however, the form of sanctions as comprehensive must be substituted with targeted sanctions. The international community would support a sanctions regime that is more targeted and distinguishes between civilians and the politics related to the implementation of sanctions. The targeted sanctions should be related to the banning of goods, for example related to weapons programs and not humanitarian and civilian goods.

For economic sanctions to last for over a decade with serious humanitarian implications and no positive outcome, it is only logical to end such policy and move on to specific sanctions that target the government and not the civilian population. This of course has to be followed by a serious timeline and a clear and realistic set of goals of what needs to be accomplished for lifting of sanctions. There must be a serious level of political commitment on the implementation of sanctions. The members of the Security Council must be very clear on their objectives prior to imposing sanctions and they must be accountable for their role as peacemakers and must always be bound by the international laws that they must uphold. 
UN organizations have done extensive monitoring and research on the humanitarian crisis in Iraq and have defined a set of indicators such as child and infant mortality rate (as shown in Chapter Two) as evidence to show the impact of sanctions on civilian life. These indicators should have been used as early warning signs to how the Iraqi population, especially children and women are coping under the UN sanctions regime. Such research and indicators should not be taken lightly as they are a marker of what has yet to come, a humanitarian genocide.

Any sanctions regime must be built upon international human rights and humanitarian laws. The Security Council must introduce programs that secure the political, economic and social growth and development of a country under a sanctions regime. Furthermore, a reform of the Security Council is urgently needed. The idea that a country's fate lies solely under the authority of one or two countries is ridiculous and appalling. For instance, the veto power is a unilateral tool for decision-making, which contradicts the multilateral foundation of the UN. In the case of Iraq, the U.S. and the U.K., as shown in previous Chapters have exposed their legacy of hegemony and their interest in Iraqi oil, especially when it is known that there are about 112 billion barrels of oil reserves in Iraq (Bell, 2004: 134). The power that is bequeathed upon the Security Council should not be manipulated and hence, there must be continuous monitoring of Security Council's actions and decisions, especially when enforcing economic sanctions that have proven to be quite devastating on an entire civilian population.

Sanctions policy must be accompanied by supportive measures as the ones mentioned above to achieve realistic and attained goals. After examining the injustice and the massive destruction imposed on a people, the question remains: do sanctions 
survive legal challenges to their uses and abuses? If policy makers design a sanctions regime with careful research and implementation in concurrence with international human rights and humanitarian laws, sanctions could be an effective alternative to war and a successful tool of foreign policy and multilateral diplomacy in inter-state relations. 


\section{Appendices}

APPENDIX I: Office of the Iraq Programme

Oil for Food - http://www.un.org/depts/oip/background/phases.html

Phases of the Programme

\begin{tabular}{|c|c|c|c|}
\hline Phase & From & To & $\begin{array}{l}\text { Authorized by Security Council } \\
\text { Resolution... }\end{array}$ \\
\hline I & $\begin{array}{l}10 \text { December } \\
1996\end{array}$ & 7 June 1997 & $\frac{\text { SCR } 986(1995)}{14 \text { April } 1995}$ \\
\hline II & 8 June 1997 & 4 December 1997 & $\frac{\text { SCR } 1111(1997)}{4 \text { June } 1997}$ \\
\hline III & $\begin{array}{l}5 \text { December } \\
1997\end{array}$ & 29 May 1998 & $\frac{\operatorname{SCR} 1143(1997)}{4 \text { December } 1997}$ \\
\hline IV & 30 May 1998 & 25 November 1998 & $\frac{\text { SCR } 1153(1998)}{20 \text { February } 1998}$ \\
\hline V & $\begin{array}{l}26 \text { November } \\
1998\end{array}$ & 24 May 1999 & $\frac{\text { SCR } 1210(1998)}{24 \text { November } 1998}$ \\
\hline \multirow[t]{3}{*}{ VI } & 25 May 1999 & 20 November 1999 & $\frac{\text { SCR } 1242(1999)}{21 \text { May } 1999}$ \\
\hline & & $\begin{array}{c}\text { Extends phase VI until } 4 \\
\text { December } 1999\end{array}$ & $\frac{\text { SCR } 1275(1999)}{19 \text { November } 1999}$ \\
\hline & & $\begin{array}{c}\text { Extends phase VI until } 11 \\
\text { December } 1999\end{array}$ & $\frac{\text { SCR } 1280(1999)}{3 \text { December } 1999}$ \\
\hline VII & $\begin{array}{l}12 \text { December } \\
1999\end{array}$ & 8 June 2000 & $\frac{\text { SCR } 1281(1999)}{10 \text { December } 1999}$ \\
\hline VIII & 9 June 2000 & 5 December 2000 & $\frac{\text { SCR } 1302(2000)}{8 \text { June } 2000}$ \\
\hline \multirow[t]{2}{*}{ IX } & $\begin{array}{l}6 \text { December } \\
2000\end{array}$ & 3 June 2001 & $\frac{\text { SCR } 1330(2000)}{5 \text { December } 2000}$ \\
\hline & & Extends phase IX until 3 July 2001 & $\frac{\text { SCR } 1352(2001)}{1 \text { June } 2001}$ \\
\hline $\mathrm{X}$ & 4 July 2001 & 30 November 2001 & $\frac{\text { SCR } 1360(2001)}{3 \text { July } 2001}$ \\
\hline $\mathrm{XI}$ & $\begin{array}{l}1 \text { December } \\
2001\end{array}$ & 29 May 2002 & $\frac{\text { SCR } 1382(2001)}{29 \text { November } 2001}$ \\
\hline \multirow[t]{2}{*}{ XII } & 30 May 2002 & 25 November 2002 & $\frac{\text { SCR } 1409(2002)}{14 \text { May } 2002}$ \\
\hline & & $\begin{array}{l}\text { Extends phase XII until } 4 \text { December } \\
\qquad 2002\end{array}$ & $\frac{\text { SCR } 1443(2002)}{25 \text { November } 2002}$ \\
\hline XIII & $\begin{array}{l}5 \text { December } \\
2002\end{array}$ & 3 June 2003 & $\frac{\text { SCR } 1447(2002)}{4 \text { December } 2002}$ \\
\hline
\end{tabular}




\section{Security Council Resolutions}

(Related to the Oil-for-Food Programme)

Resolution 1483, of 22 May 2003 lifted civilian sanctions and provided for termination of the Oil-for-Food Programme within six months, transferring responsibility for the administration of any remaining activity to The Authority representing the occupying powers.

Resolution 1476, of 24 April 2003 was adpoted by the Security Council, extending the provisions contained in paragraph 4 of resolution 1472 (2003) until 3 June,2003. Those provsions may be subject to further renewal by the Council.

Resolution 1472 of 28 March 2003 was adopted unanimously by the Security Council on 28 March to adjust the Oil-for-Food Programme and give the Secretary-General authority for a period of 45 days to facilitate the delivery and receipt of goods contracted by the Government of Iraq for the humanitarian needs of its people.

Resolution 1454 of 30 December, introduces changes to the list of goods subject to review and approval by the 661 Committee under the United Nations oil-for-food programme. The changes to the goods review list (GRL) also require a thorough review of the List and its procedures, both 90 days after the commencement of phase Xlll of the programme (5 December 2002) and prior to the end of its defined 180-day period (3 June 2003).

Resolution 1447 of 4 December 2002 - renews the oil-for-food programme for another 180 days until 3 June 2003 (phase XIII).

Resolution 1443 of 25 November 2002 - extends phase XII for another 9 days until 4 December 2002.

Resolution 1409 of 14 May 2002 introduces the Goods Review List (GRL) and a new set of procedures for the processing of contracts for humanitarian supplies and equipment. It marks the second most significant change in the programme after resolution 1284 (1999). The resolution also extends the programme for another 180 days (phase XII), effective 30 May 2002. The phase ends on 25 November 2002.

Resolution 1382 of 29 November 2001 - renews the oil-for-food programme for another 180 days until 29 May 2002 (phase XI).

Resolution 1360 of 3 July 2001 - renews the oil-for-food programme for another 150 days until 30 November 2001 (phase X).

Resolution 1352 of 1 June 2001 - extends the terms of resolution 1330 (2000), or phase IX, for another 30 days. 
$\underline{\text { Resolution } 1330}$ of 5 December 2000 - extends the programme for additional 180 days (phase IX).

Resolution 1302 of 8 June 2000 - renews the oil-for-food programme for another 180 days until 5 December 2000 (phase VIII).

$\underline{\text { Resolution } 1293}$ of 31 March 2000 - increases oil spare parts allocation from $\$ 300$ million to $\$ 600$ million under phases VI and VII.

Resolution 1284 of 17 December 1999 - stresses the importance of a comprehensive approach to the full implementation of all relevant Security Council resolutions regarding Iraq and the need for Iraqi compliance with these resolutions. Establishes, as a subsidiary body of the Council, the United Nations Monitoring, Verification and Inspection Commission (UNMOVIC) which replaces the Special Commission.

Resolution 1281 of 10 December 1999 - renews the oil for food programme for a further six months (phase VII).

Resolution 1280 of 3 December 1999 - extends phase VI of the oil for food programme for one week, until 11 December 1999.

Resolution 1275 of 19 November 1999 - extends phase VI of the oil for food programme for two weeks, until 4 December 1999.

Resolution 1266 of 4 October 1999 , permits Iraq to export an additional amount of $\$ 3.04$ billion of oil in phase VI to make up for the deficit in revenue in phases IV and V.

Resolution 1242 of 21 May1999 - renews the oil for food programme for a further six months.

Resolution 1210 of 24 November 1998, renews the oil for food programme for a further six months from 26 November at the higher levels established by resolution 1153 and including additional oil spare parts.

Resolution 1175 of 19 June 1998 , authorises Iraq to buy $\$ 300$ million worth of oil spare parts in order to reach the ceiling of $\$ 5.256$ billion.

Resolution 1158 of 25 March 1998, permits Iraq to export additional oil in the 90 days from 5 March, 1998 to compensate for delayed resumption of oil production and reduced oil prices.

$\underline{\text { Resolution } 1153}$ of 20 February 1998 , allows the export of $\$ 5.256$ billion of Iraqi oil.

$\underline{\text { Resolution } 1143}$ of 4 December 1997, extends the oil-for-food Programme for another 180 days 
Resolution 1129 of 12 September 1997, decides that the provisions of resolution 1111 (1997) should remain in force, but authorizes special provisions to allow Iraq to sell petroleum in a more favourable time frame.

Resolution 1111 of 4 June 1997, extends the term of SCR 986 (1995) another 180 days.

Resolution 1051 of 27 March 1996, establishes the export/import monitoring system for Iraq.

Resolution 986 of 14 April 1995, enables Iraq to sell up to $\$ 1$ billion of oil every 90 days and use the proceeds for humanitarian supplies to the country; and sets terms of reference for the Oil-for-Food Programme.

Resolution 778 of 2 October 1992, authorizes transferring back money produced by any Iraqi oil transaction on or after 6 Aug 90 and which had been deposited into the Escrow account, to the states or accounts concerned for so long as the oil exports take place or until sanctions are lifted.

Resolution 712 of 19 September 1991, confirms the sum of $\$ 1.6$ billion to be raised by the sale of Iraqi oil in a six month period to fund an oil for food programme.

Resolution 706 of 15 August 1991, sets outs a mechanism for an oil-for-food programme and authorizes an escrow account to be established by the Secretary-General.

Resolution 687 of 3 April 1991, sets terms for a cease-fire, maintains the terms of the embargo.

Resolution 661 of 6 August 1990, imposes comprehensive economic sanctions on Iraq exempting food and medicine and establishes the 661 Committee to oversee implementation of the sanctions. 


\section{APPENDIX III:}

\section{RESOLUTION 986 (1995)}

Adopted by the Security Council at its 3519 th meeting,

on 14 April 1995

(www.un.org)

The Security Council,

Recalling its previous relevant resolutions,

Concerned by the serious nutritional and health situation of the Iraqi population, and by the risk of a further deterioration in this situation,

Convinced of the need as a temporary measure to provide for the humanitarian needs of the Iraqi people until the fulfilment by Iraq of the relevant Security Council resolutions, including notably resolution 687 (1991) of 3 April 1991, allows the Council to take further action with regard to the prohibitions referred to in resolution 661 (1990) of 6 August 1990, in accordance with the provisions of those resolutions,

Convinced also of the need for equitable distribution of humanitarian relief to all segments of the Iraqi population throughout the country,

Reaffirming the commitment of all Member States to the sovereignty and territorial integrity of Iraq,

Acting under Chapter VII of the Charter of the United Nations,

1.Authorizes States, notwithstanding the provisions of paragraphs 3 (a), 3 (b) and 4 of resolution 661 (1990) and subsequent relevant resolutions, to permit the import of petroleum and petroleum products originating in Iraq, including financial and other essential transactions directly relating thereto, sufficient to produce a sum not exceeding a total of one billion United States dollars every 90 days for the purposes set out in this resolution and subject to the following conditions:

(a)Approval by the Committee established by resolution 661 (1990), in order to ensure the transparency of each transaction and its conformity with the other provisions of this resolution, after submission of an application by the State concerned, endorsed by the Government of Iraq, for each proposed purchase of Iraqi petroleum and petroleum products, including details of the purchase price at fair market value, the export route, the opening of a letter of credit payable to the escrow account to be established by the 
Secretary-General for the purposes of this resolution, and of any other directly related financial or other essential transaction;

(b)Payment of the full amount of each purchase of Iraqi petroleum and petroleum products directly by the purchaser in the State concerned into the escrow account to be established by the Secretary-General for the purposes of this resolution;

2.Authorizes Turkey, notwithstanding the provisions of paragraphs 3 (a), 3 (b) and 4 of resolution 661 (1990) and the provisions of paragraph 1 above, to permit the import of petroleum and petroleum products originating in Iraq sufficient, after the deduction of the percentage referred to in paragraph 8 (c) below for the Compensation Fund, to meet the pipeline tariff charges, verified as reasonable by the independent inspection agents referred to in paragraph 6 below, for the transport of Iraqi petroleum and petroleum products through the KirkU.K.- Yumurtalik pipeline in Turkey authorized by paragraph 1 above;

3.Decides that paragraphs 1 and 2 of this resolution shall come into force at 00.01 Eastern Standard Time on the day after the President of the Council has informed the members of the Council that he has received the report from the Secretary-General requested in paragraph 13 below, and shall remain in force for an initial period of 180 days unless the Council takes other relevant action with regard to the provisions of resolution 661 (1990);

4.Further decides to conduct a thorough review of all aspects of the implementation of this resolution 90 days after the entry into force of paragraph 1 above and again prior to the end of the initial 180 day period, on receipt of the reports referred to in paragraphs 11 and 12 below, and expresses its intention, prior to the end of the 180 day period, to consider favourably

renewal of the provisions of this resolution, provided that the reports referred to in paragraphs 11 and 12 below indicate that those provisions are being satisfactorily implemented;

5.Further decides that the remaining paragraphs of this resolution shall come into force forthwith;

6.Directs the Committee established by resolution 661 (1990) to monitor the sale of petroleum and petroleum products to be exported by Iraq via the KirkU.K.-Yumurtalik pipeline from Iraq to Turkey and from the Mina al-Bakr oil terminal, with the assistance of independent inspection agents appointed by the Secretary-General, who will keep the Committee informed of the amount of petroleum and petroleum products exported from Iraq after the date of entry into force of paragraph 1 of this resolution, and will verify that the purchase price of the petroleum and petroleum products is reasonable in the light of prevailing market conditions, and that, for the purposes of the arrangements set out in this resolution, the larger share of the petroleum and petroleum products is shipped via the KirkU.K.-Yumurtalik pipeline and the remainder is exported from the Mina al-Bakr oil terminal; 
7.Requests the Secretary-General to establish an escrow account for the purposes of this resolution, to appoint independent and certified public accountants to audit it, and to keep the Government of Iraq fully informed;

8.Decides that the funds in the escrow account shall be used to meet the humanitarian needs of the Iraqi population and for the following other purposes, and requests the Secretary-General to use the funds deposited in the escrow account:

(a)To finance the export to Iraq, in accordance with the procedures of the Committee established by resolution 661 (1990), of medicine, health supplies, foodstuffs, and materials and supplies for essential civilian needs, as referred to in paragraph 20 of resolution 687 (1991) provided that:

(i) Each export of goods is at the request of the Government of Iraq;

(ii)Iraq effectively guarantees their equitable distribution, on the basis of a plan submitted to and approved by the Secretary-General, including a description of the goods to be purchased;

(iii) The Secretary-General receives authenticated confirmation that the exported goods concerned have arrived in Iraq;

(b)To complement, in view of the exceptional circumstances prevailing in the three Governorates mentioned below, the distribution by the Government of Iraq of goods imported under this resolution, in order to ensure an equitable distribution of humanitarian relief to all segments of the Iraqi population throughout the country, by providing between 130 million and 150 million United States dollars every 90 days to the United Nations Inter-Agency Humanitarian Programme operating within the sovereign territory of Iraq in the three northern Governorates of DihoU.K., Arbil and Suleimaniyeh, except that if less than one billion United States dollars worth of petroleum or petroleum products is sold during any 90 day period, the Secretary-General may provide a proportionately smaller amount for this purpose;

(c)To transfer to the Compensation Fund the same percentage of the funds deposited in the escrow account as that decided by the Council in paragraph 2 of resolution 705 (1991) of 15 August 1991;

(d)To meet the costs to the United Nations of the independent inspection agents and the certified public accountants and the activities associated with implementation of this resolution;

(e)To meet the current operating costs of the Special Commission, pending subsequent payment in full of the costs of carrying out the tasks authorized by section $\mathrm{C}$ of resolution 687 (1991); 
(f)To meet any reasonable expenses, other than expenses payable in Iraq, which are determined by the Committee established by resolution 661 (1990) to be directly related to the export by Iraq of petroleum and petroleum products permitted under paragraph 1 above or to the export to Iraq, and activities directly necessary therefor, of the parts and equipment permitted under paragraph 9 below;

(g)To make available up to 10 million United States dollars every 90 days from the funds deposited in the escrow account for the payments envisaged under paragraph 6 of resolution 778 (1992) of 2 October 1992;

9.Authorizes States to permit, notwithstanding the provisions of paragraph 3 (c) of resolution 661 (1990):

(a)The export to Iraq of the parts and equipment which are essential for the safe operation of the KirkU.K.-Yumurtalik pipeline system in Iraq, subject to the prior approval by the Committee established by resolution 661 (1990) of each export contract;

(b)Activities directly necessary for the exports authorized under subparagraph (a) above, including financial transactions related thereto;

10.Decides that, since the costs of the exports and activities authorized under paragraph 9 above are precluded by paragraph 4 of resolution 661 (1990) and by paragraph 11 of resolution 778 (1991) from being met from funds frozen in accordance with those provisions, the cost of such exports and activities may, until funds begin to be paid into the escrow account established for the purposes of this resolution, and following approval in each case by the Committee established by resolution 661 (1990), exceptionally be financed by letters of credit, drawn against future oil sales the proceeds of which are to be deposited in the escrow account;

11.Requests the Secretary-General to report to the Council 90 days after the date of entry into force of paragraph 1 above, and again prior to the end of the initial 180 day period, on the basis of observation by United Nations personnel in Iraq, and on the basis of consultations with the Government of Iraq, on whether Iraq has ensured the equitable distribution of medicine, health supplies, foodstuffs, and materials and supplies for essential civilian needs, financed in accordance with paragraph 8 (a) above, including in his reports any observations he may have on the adequacy of the revenues to meet Iraq's humanitarian needs, and on Iraq's capacity to export sufficient quantities of petroleum and petroleum products to produce the sum referred to in paragraph 1 above;

12.Requests the Committee established by resolution 661 (1990), in close coordination with the Secretary-General, to develop expedited procedures as necessary to implement the arrangements in paragraphs $1,2,6,8,9$ and 10 of this resolution and to report to the Council 90 days after the date of entry into force of paragraph 1 above and again prior to the end of the initial 180 day period on the implementation of those arrangements; 
13. Requests the Secretary-General to take the actions necessary to ensure the effective implementation of this resolution, authorizes him to enter into any necessary arrangements or agreements, and requests him to report to the Council when he has done so;

14.Decides that petroleum and petroleum products subject to this resolution shall while under Iraqi title be immune from legal proceedings and not be subject to any form of attachment, garnishment or execution, and that all States shall take any steps that may be necessary under their respective domestic legal systems to assure this protection, and to ensure that the proceeds of the sale are not diverted from the purposes laid down in this resolution;

15.Affirms that the escrow account established for the purposes of this resolution enjoys the privileges and immunities of the United Nations;

16.Affirms that all persons appointed by the Secretary-General for the purpose of implementing this resolution enjoy privileges and immunities as experts on mission for the United Nations in accordance with the Convention on the Privileges and Immunities of the United Nations, and requires the Government of Iraq to allow them full freedom of movement and all necessary facilities for the discharge of their duties in the implementation of this resolution;

17.Affirms that nothing in this resolution affects Iraq's duty scrupulously to adhere to all of its obligations concerning servicing and repayment of its foreign debt, in accordance with the appropriate international mechanisms;

18.Also affirms that nothing in this resolution should be construed as infringing the sovereignty or territorial integrity of Iraq;

19.Decides to remain seized of the matter.

Back to List of UN Security Council Resolutions on Iraq Home Page 


\section{APPENDIX IV:}

\section{UN RESOLUTION 661}

(www.un.org)

Adopted by the Security Council at its 2933rd meeting on 6 August 1990

The Security Council, Reaffirming its resolution 660 (1990) of 2 August 1990,

Deeply concerned that that resolution has not been implemented and that the invasion by Iraq of Kuwait continues with further loss of human life and material destruction,

Determined to bring the invasion and occupation of Kuwait by Iraq to an end and to restore the sovereignty, independence and territorial integrity of Kuwait,

Noting that the legitimate Government of Kuwait has expressed its readiness to comply with resolution $660(1990)$,

Mindful of its responsibilities under the Charter of the United Nations for the maintenance of international peace and security,

Affirming the inherent right of individual or collective self-defence, in response to the armed attack by Iraq against Kuwait, in accordance with Article 51 of the Charter,

Acting under Chapter VII of the Charter of the United Nations,

1. Determines that Iraq so far has failed to comply with paragraph 2 of resolution $\underline{660}$ (1990) and has usurped the authority of the legitimate Government of Kuwait;

2. Decides, as a consequence, to take the following measures to secure compliance of Iraq with paragraph 2 of resolution $\underline{660}$ (1990) and to restore the authority of the legitimate Government of Kuwait;

3. Decides that all States shall prevent:

(a) The import into their territories of all commodities and products originating in Iraq or Kuwait exported there from after the date of the present resolution;

(b) Any activities by their nationals or in their territories which would promote or are calculated to promote the export or trans-shipment of any commodities or products from Iraq or Kuwait; and any dealings by their nationals or their flag vessels or in their territories in any commodities or products originating in Iraq or Kuwait and exported therefrom after the date of the present resolution, including in particular any transfer of funds to Iraq or Kuwait for the purposes of such activities or dealings;

(c) The sale or supply by their nationals or from their territories or using their flag vessels 
of any commodities or products, including weapons or any other military equipment, whether or not originating in their territories but not including supplies intended strictly for medical purposes, and, in humanitarian circumstances, foodstuffs, to any person or body in Iraq or Kuwait or to any person or body for the purposes of any business carried on in or operated from Iraq or Kuwait, and any activities by their nationals or in their territories which promote or are calculated to promote such sale or supply of such commodities or products;

4. Decides that all States shall not make available to the Government of Iraq or to any commercial, industrial or public utility undertaking in Iraq or Kuwait, any funds or any other financial or economic resources and shall prevent their nationals and any persons within their territories from removing from their territories or otherwise making available to that Government or to any such undertaking any such funds or resources and from remitting any other funds to persons or bodies within Iraq or Kuwait, except payments exclusively for strictly medical or humanitarian purposes and, in humanitarian circumstances, foodstuffs;

5. Calls upon all States, including States non-members of the United Nations, to act strictly in accordance with the provisions of the present resolution notwithstanding any contract entered into or licence granted before the date of the present resolution;

6. Decides to establish, in accordance with rule 28 of the provisional rules of procedure of the Security Council, a Committee of the Security Council consisting of all the members of the Council, to undertake the following tasks and to report on its work to the Council with its observations and recommendations:

(a) To examine the reports on the progress of the implementation of the present resolution which will be submitted by the Secretary-General;

(b) To seek from all States further information regarding the action taken by them concerning the effective implementation of the provisions laid down in the present resolution;

7. Calls upon all States to co-operate fully with the Committee in the fulfilment of its task, including supplying such information as may be sought by the Committee in pursuance of the present resolution;

8. Requests the Secretary-General to provide all necessary assistance to the Committee and to make the necessary arrangements in the Secretariat for the purpose

9. Decides that, notwithstanding paragraphs 4 through 8 above, nothing in the present resolution shall prohibit assistance to the legitimate Government of Kuwait, and calls upon all States: 
(a) To take appropriate measures to protect assets of the legitimate Government of Kuwait and its agencies;

(b) Not to recognize any regime set up by the occupying Power;

10. Requests the Secretary-General to report to the Council on the progress of the implementation of the present resolution, the first report to be submitted within thirty days;

11. Decides to keep this item on its agenda and to continue its efforts to put an early end to the invasion by Iraq. 


\section{APPENDIX V:}

\section{RESOLUTION 687}

Adopted by the Security Council at its 2981st meeting on 3 April 1991

(www.un.org)

The Security Council,

Recalling and reaffirming its resolutions $\underline{660}$ (1990), $\underline{661}(1990), \underline{662}(1990), \underline{664}(1990)$, $\underline{665}(1990), \underline{666}(1990), \underline{667}(1990), 669$ (1990), $\underline{670}$ (1990), 674 (1990), 677 (1990), and $\underline{678}$ (1990), and $\underline{686}(1991)$

Welcoming the restoration to Kuwait of its sovereignty, independence and territorial integrity and the return of its legitimate Government,

Affirming the commitment of all Member States to the sovereignty, territorial integrity and political independence of Kuwait and Iraq, and noting the intention expressed by the Member States cooperating with Kuwait under paragraph 2 of resolution 678 (1990) to bring their military presence in Iraq to an end as soon as possible consistent with paragraph 8 of resolution $\underline{686}(1991)$,

Reaffirming the need to be assured of Iraq's peaceful intentions in the light of its unlawful invasion and occupation of Kuwait,

Taking note of the letter sent by the Minister for Foreign Affairs of Iraq on 27 February 1991 and those sent pursuant to resolution $\underline{686}(1991)$,

Noting that Iraq and Kuwait, as independent sovereign States, signed at Baghdad on 4 October 1963 "Agreed Minutes Between the State of Kuwait and the Republic of Iraq Regarding the Restoration of Friendly Relations, Recognition and Related Matters", thereby recognizing formally the boundary between Iraq and Kuwait and the allocation of islands, which were registered with the United Nations in accordance with Article 102 of the Charter of the United Nations and in which Iraq recognized the independence and complete sovereignty of the State of Kuwait within its borders as specified and accepted in the letter of the Prime Minister of Iraq dated 21 July 1932, and as accepted by the Ruler of Kuwait in his letter dated 10 August 1932, Conscious of the need for demarcation of the said boundary,

Conscious also of the statements by Iraq threatening to use weapons in violation of its obligations under the Geneva Protocol for the Prohibition of the Use in War of Asphyxiating, Poisonous or Other Gases, and of Bacteriological Methods of Warfare, signed at Geneva on 17 June 1925, and of its prior use of chemical weapons and affirming that grave consequences would follow any further use by Iraq of such weapons, 
Recalling that Iraq has subscribed to the Declaration adopted by all States participating in the Conference of States Parties to the 1925 Geneva Protocol and Other Interested States, held in Paris from 7 to 11 January 1989, establishing the objective of universal elimination of chemical and biological weapons,

Recalling also that Iraq has signed the Convention on the Prohibition of the Development, Production and Stockpiling of Bacteriological (Biological) and Toxin Weapons and on Their Destruction, of 10 April 1972,

Noting the importance of Iraq ratifying this Convention,

Noting moreover the importance of all States adhering to this Convention and encouraging its forthcoming Review Conference to reinforce the authority, efficiency and universal scope of the convention,

Stressing the importance of an early conclusion by the Conference on Disarmament of its work on a Convention on the Universal Prohibition of Chemical Weapons and of universal adherence thereto,

Aware of the use by Iraq of ballistic missiles in unprovoked attacks and therefore of the need to take specific measures in regard to such missiles located in Iraq,

Concerned by the reports in the hands of Member States that Iraq has attempted to acquire materials for a nuclear-weapons programme contrary to its obligations under the Treaty on the Non-Proliferation of Nuclear Weapons of 1 July 1968,

Recalling the objective of the establishment of a nuclear-weapons-free zone in the region of the Middle East,

Conscious of the threat that all weapons of mass destruction pose to peace and security in the area and of the need to work towards the establishment in the Middle East of a zone free of such weapons,

Conscious also of the objective of achieving balanced and comprehensive control of armaments in the region,

Conscious further of the importance of achieving the objectives noted above using all available means, including a dialogue among the States of the region,

Noting that resolution $\underline{666}$ (1991) marked the lifting of the measures imposed by resolution $\underline{61}$ (1990) in so far as they applied to Kuwait,

Noting that despite the progress being made in fulfilling the obligations of resolution 686 (1991), many Kuwaiti and third country nationals are still not accounted for and property remains unreturned, 
Recalling the International Convention against the Taking of Hostages, opened for signature at New York on 18 December 1979, which categorizes all acts of taking hostages as manifestations of international terrorism,

Deploring threats made by Iraq during the recent conflict to make use of terrorism against targets outside Iraq and the taking of hostages by Iraq,

Taking note with grave concern of the reports of the Secretary-General of 20 March 1991 and 28 March 1991, and conscious of the necessity to meet urgently the humanitarian needs in Kuwait and Iraq,

Bearing in mind its objective of restoring international peace and security in the area as set out in recent resolutions of the Security Council,

Conscious of the need to take the following measures acting under Chapter VII of the Charter,

1. Affirms all thirteen resolutions noted above, except as expressly changed below to achieve the goals of this resolution, including a formal cease-fire;

A 2. Demands that Iraq and Kuwait respect the inviolability of the international boundary and the allocation of islands set out in the "Agreed Minutes Between the State of Kuwait and the Republic of Iraq Regarding the Restoration of Friendly Relations, Recognition and Related Matters", signed by them in the exercise of their sovereignty at Baghdad on 4 October 1963 and registered with the United Nations and published by the United Nations in document 7063, United Nations, Treaty Series, 1964;

3. Calls upon the Secretary-General to lend his assistance to make arrangements with Iraq and Kuwait to demarcate the boundary between Iraq and Kuwait, drawing on appropriate material, including the map transmitted by Security Council document S/22412 and to report back to the Security Council within one month;

4. Decides to guarantee the inviolability of the above-mentioned international boundary and to take as appropriate all necessary measures to that end in accordance with the Charter of the United Nations;

B 5. Requests the Secretary-General, after consulting with Iraq and Kuwait, to submit within three days to the Security Council for its approval a plan for the immediate deployment of a United Nations observer unit to monitor the Khor Abdullah and a demilitarized zone, which is hereby established, extending ten kilometres into Iraq and five kilometres into Kuwait from the boundary referred to in the "Agreed Minutes Between the State of Kuwait and the Republic of Iraq Regarding the Restoration of Friendly Relations, Recognition and Related Matters" of 4 October 1963; to deter violations of the boundary through its presence in and surveillance of the demilitarized zone; to observe any hostile or potentially hostile action mounted from the territory of 
one State to the other; and for the Secretary-General to report regularly to the Security Council on the operations of the unit, and immediately if there are serious violations of the zone or potential threats to peace;

6. Notes that as soon as the Secretary-General notifies the Security Council of the completion of the deployment of the United Nations observer unit, the conditions will be established for the Member States cooperating with Kuwait in accordance with resolution $\underline{678}$ (1990) to bring their military presence in Iraq to an end consistent with resolution $\underline{686}(1991)$;

C 7. Invites Iraq to reaffirm unconditionally its obligations under the Geneva Protocol for the Prohibition of the Use in War of Asphyxiating, Poisonous or Other Gases, and of Bacteriological Methods of Warfare, signed at Geneva on 17 June 1925, and to ratify the Convention on the Prohibition of the Development, Production and Stockpiling of Bacteriological (Biological) and Toxin Weapons and on Their Destruction, of 10 April 1972;

8. Decides that Iraq shall unconditionally accept the destruction, removal, or rendering harmless, under international supervision, of: (a) All chemical and biological weapons and all stocks of agents and all related subsystems and components and all research, development, support and manufacturing facilities; (b) All ballistic missiles with a range greater than 150 kilometres and related major parts, and repair and production facilities;

9. Decides, for the implementation of paragraph 8 above, the following:

(a) Iraq shall submit to the Secretary-General, within fifteen days of the adoption of the present resolution, a declaration of the locations, amounts and types of all items specified in paragraph 8 and agree to urgent, on-site inspection as specified below;

(b) The Secretary-General, in consultation with the appropriate Governments and, where appropriate, with the Director-General of the World Health Organization, within fortyfive days of the passage of the present resolution, shall develop, and submit to the Council for approval, a plan calling for the completion of the following acts within fortyfive days of such approval:

(i) The forming of a Special Commission, which shall carry out immediate on-site inspection of Iraq's biological, chemical and missile capabilities, based on Iraq's declarations and the designation of any additional locations by the Special Commission itself;

(ii) The yielding by Iraq of possession to the Special Commission for destruction, removal or rendering harmless, taking into account the requirements of public safety, of all items specified under paragraph 8 (a) above, including items at the additional locations designated by the Special Commission under paragraph 9 (b) (i) above and the destruction by Iraq, under the supervision of the Special Commission, of all its missile capabilities, including launchers, as specified under paragraph 8 (b) above; (iii) The provision by the Special Commission of the assistance and cooperation to the Director- 
General of the International Atomic Energy Agency required in paragraphs 12 and 13 below;

10. Decides that Iraq shall unconditionally undertake not to use, develop, construct or acquire any of the items specified in paragraphs 8 and 9 above and requests the Secretary-General, in consultation with the Special Commission, to develop a plan for the future ongoing monitoring and verification of Iraq's compliance with this paragraph, to be submitted to the Security Council for approval within one hundred and twenty days of the passage of this resolution;

11. Invites Iraq to reaffirm unconditionally its obligations under the Treaty on the NonProliferation of Nuclear Weapons of 1 July 1968;

12. Decides that Iraq shall unconditionally agree not to acquire or develop nuclear weapons or nuclear-weapons-usable material or any subsystems or components or any research, development, support or manufacturing facilities related to the above; to submit to the Secretary-General and the Director-General of the International Atomic Energy Agency within fifteen days of the adoption of the present resolution a declaration of the locations, amounts, and types of all items specified above; to place all of its nuclearweapons-usable materials under the exclusive control, for custody and removal, of the International Atomic Energy Agency, with the assistance and cooperation of the Special Commission as provided for in the plan of the Secretary-General discussed in paragraph 9 (b) above; to accept, in accordance with the arrangements provided for in paragraph 13 below, urgent on-site inspection and the destruction, removal or rendering harmless as appropriate of all items specified above; and to accept the plan discussed in paragraph 13 below for the future ongoing monitoring and verification of its compliance with these undertakings;

13. Requests the Director-General of the International Atomic Energy Agency, through the Secretary-General, with the assistance and cooperation of the Special Commission as provided for in the plan of the Secretary-General in paragraph 9 (b) above, to carry out immediate on-site inspection of Iraq's nuclear capabilities based on Iraq's declarations and the designation of any additional locations by the Special Commission; to develop a plan for submission to the Security Council within forty-five days calling for the destruction, removal, or rendering harmless as appropriate of all items listed in paragraph 12 above; to carry out the plan within forty-five days following approval by the Security Council; and to develop a plan, taking into account the rights and obligations of Iraq under the Treaty on the Non-Proliferation of Nuclear Weapons of 1 July 1968, for the future ongoing monitoring and verification of Iraq's compliance with paragraph 12 above, including an inventory of all nuclear material in Iraq subject to the Agency's verification and inspections to confirm that Agency safeguards cover all relevant nuclear activities in Iraq, to be submitted to the Security Council for approval within one hundred and twenty days of the passage of the present resolution; 
14. Takes note that the actions to be taken by Iraq in paragraphs $8,9,10,11,12$ and 13 of the present resolution represent steps towards the goal of establishing in the Middle East a zone free from weapons of mass destruction and all missiles for their delivery and the objective of a global ban on chemical weapons;

D 15. Requests the Secretary-General to report to the Security Council on the steps taken to facilitate the return of all Kuwaiti property seized by Iraq, including a list of any property that Kuwait claims has not been returned or which has not been returned intact;

E 16. Reaffirms that Iraq, without prejudice to the debts and obligations of Iraq arising prior to 2 August 1990, which will be addressed through the normal mechanisms, is liable under international law for any direct loss, damage, including environmental damage and the depletion of natural resources, or injury to foreign Governments, nationals and corporations, as a result of Iraq's unlawful invasion and occupation of Kuwait;

17. Decides that all Iraqi statements made since 2 August 1990 repudiating its foreign debt are null and void, and demands that Iraq adhere scrupulously to all of its obligations concerning servicing and repayment of its foreign debt;

18. Decides also to create a fund to pay compensation for claims that fall within paragraph 16 above and to establish a Commission that will administer the fund;

19. Directs the Secretary-General to develop and present to the Security Council for decision, no later than thirty days following the adoption of the present resolution, recommendations for the fund to meet the requirement for the payment of claims established in accordance with paragraph 18 above and for a programme to implement the decisions in paragraphs 16, 17 and 18 above, including: administration of the fund; mechanisms for determining the appropriate level of Iraq's contribution to the fund based on a percentage of the value of the exports of petroleum and petroleum products from Iraq not to exceed a figure to be suggested to the Council by the Secretary-General, taking into account the requirements of the people of Iraq, Iraq's payment capacity as assessed in conjunction with the international financial institutions taking into consideration external debt service, and the needs of the Iraqi economy; arrangements for ensuring that payments are made to the fund; the process by which funds will be allocated and claims paid; appropriate procedures for evaluating losses, listing claims and verifying their validity and resolving disputed claims in respect of Iraq's liability as specified in paragraph 16 above; and the composition of the Commission designated above;

F 20. Decides, effective immediately, that the prohibitions against the sale or supply to Iraq of commodities or products, other than medicine and health supplies, and prohibitions against financial transactions related thereto contained in resolution $\underline{661}$ (1990) shall not apply to foodstuffs notified to the Security Council Committee established by resolution 661 (1990) concerning the situation between Iraq and Kuwait or, with the approval of that Committee, under the simplified and accelerated "no- 
objection" procedure, to materials and supplies for essential civilian needs as identified in the report of the Secretary-General dated 20 March 1991, and in any further findings of humanitarian need by the Committee;

21. Decides that the Security Council shall review the provisions of paragraph 20 above every sixty days in the light of the policies and practices of the Government of Iraq, including the implementation of all relevant resolutions of the Security Council, for the purpose of determining whether to reduce or lift the prohibitions referred to therein;

22. Decides that upon the approval by the Security Council of the programme called for in paragraph 19 above and upon Council agreement that Iraq has completed all actions contemplated in paragraphs $8,9,10,11,12$ and 13 above, the prohibitions against the import of commodities and products originating in Iraq and the prohibitions against financial transactions related thereto contained in resolution $\underline{61}$ (1990) shall have no further force or effect;

23. Decides that, pending action by the Security Council under paragraph 22 above, the Security Council Committee established by resolution 661 (1990) shall be empowered to approve, when required to assure adequate financial resources on the part of Iraq to carry out the activities under paragraph 20 above, exceptions to the prohibition against the import of commodities and products originating in Iraq;

24. Decides that, in accordance with resolution 661 (1990) and subsequent related resolutions and until a further decision is taken by the Security Council, all States shall continue to prevent the sale or supply, or the promotion or facilitation of such sale or supply, to Iraq by their nationals, or from their territories or using their flag vessels or aircraft, of:

(a) Arms and related materiel of all types, specifically including the sale or transfer through other means of all forms of conventional military equipment, including for paramilitary forces, and spare parts and components and their means of production, for such equipment;

(b) Items specified and defined in paragraphs 8 and 12 above not otherwise covered above;

(c) Technology under licensing or other transfer arrangements used in the production, utilization or stockpiling of items specified in subparagraphs (a) and (b) above;

(d) Personnel or materials for training or technical support services relating to the design, development, manufacture, use, maintenance or support of items specified in subparagraphs (a) and (b) above;

25. Calls upon all States and international organizations to act strictly in accordance with paragraph 24 above, notwithstanding the existence of any contracts, agreements, licences or any other arrangements; 
26. Requests the Secretary-General, in consultation with appropriate Governments, to develop within sixty days, for the approval of the Security Council, guidelines to facilitate full international implementation of paragraphs 24 and 25 above and paragraph 27 below, and to make them available to all States and to establish a procedure for updating these guidelines periodically;

27. Calls upon all States to maintain such national controls and procedures and to take such other actions consistent with the guidelines to be established by the Security Council under paragraph 26 above as may be necessary to ensure compliance with the terms of paragraph 24 above, and calls upon international organizations to take all appropriate steps to assist in ensuring such full compliance;

28. Agrees to review its decisions in paragraphs $22,23,24$ and 25 above, except for the items specified and defined in paragraphs 8 and 12 above, on a regular basis and in any case one hundred and twenty days following passage of the present resolution, taking into account Iraq's compliance with the resolution and general progress towards the control of armaments in the region;

29. Decides that all States, including Iraq, shall take the necessary measures to ensure that no claim shall lie at the instance of the Government of Iraq, or of any person or body in Iraq, or of any person claiming through or for the benefit of any such person or body, in connection with any contract or other transaction where its performance was affected by reason of the measures taken by the Security Council in resolution 661 (1990) and related resolutions;

G 30. Decides that, in furtherance of its commitment to facilitate the repatriation of all Kuwaiti and third country nationals, Iraq shall extend all necessary cooperation to the International Committee of the Red Cross, providing lists of such persons, facilitating the access of the International Committee of the Red Cross to all such persons wherever located or detained and facilitating the search by the International Committee of the Red Cross for those Kuwaiti and third country nationals still unaccounted for;

31. Invites the International Committee of the Red Cross to keep the Secretary-General apprised as appropriate of all activities undertaken in connection with facilitating the repatriation or return of all Kuwaiti and third country nationals or their remains present in Iraq on or after 2 August 1990;

H 32. Requires Iraq to inform the Security Council that it will not commit or support any act of international terrorism or allow any organization directed towards commission of such acts to operate within its territory and to condemn unequivocally and renounce all acts, methods and practices of terrorism;

I 33. Declares that, upon official notification by Iraq to the Secretary-General and to the Security Council of its acceptance of the provisions above, a formal cease-fire is effective 
between Iraq and Kuwait and the Member States cooperating with Kuwait in accordance with resolution $\underline{678}(1990)$;

34. Decides to remain seized of the matter and to take such further steps as may be required for the implementation of the present resolution and to secure peace and security in the area. 
APPENDIX VI:

\begin{tabular}{|c|c|c|}
\hline Phase I-VIII & $\begin{array}{c}\text { Volume of Oil (Millions of } \\
\text { Barrels) }\end{array}$ & $\begin{array}{l}\text { Value of Oil Exported (\$ } \\
\text { million) }\end{array}$ \\
\hline One & 120 & 2150 \\
\hline Two & 127 & 2125 \\
\hline Three & 182 & 2085 \\
\hline Four & 308 & 3027 \\
\hline Five & 360.8 & 3947 \\
\hline Six & 389.6 & 7402 \\
\hline Seven & 343.4 & 8302 \\
\hline Eight & 375.7 & 9564 \\
\hline Total & 2206.5 & 38602 \\
\hline Phase IX-XIII & Volume of Oil (Millions of & Value of Oil Exported (\$) million) \\
\hline Nine & Barrels) & 5638 \\
\hline Ten & 293 & 5350 \\
\hline Eleven & 300.2 & 4589 \\
\hline Twelve & 225.9 & 5639 \\
\hline Thirteen & 232.7 & 1411 \\
\hline Total & 53.7 & 22627 \\
\hline
\end{tabular}

(Source: http://www.un.org/depts/oip/background/basicfigures.html) 


\section{APPENDIX VII:}

Arrenoix $\times 1$

\section{Chart 3:}

\section{Iraq - disparitles in under-five deaths}

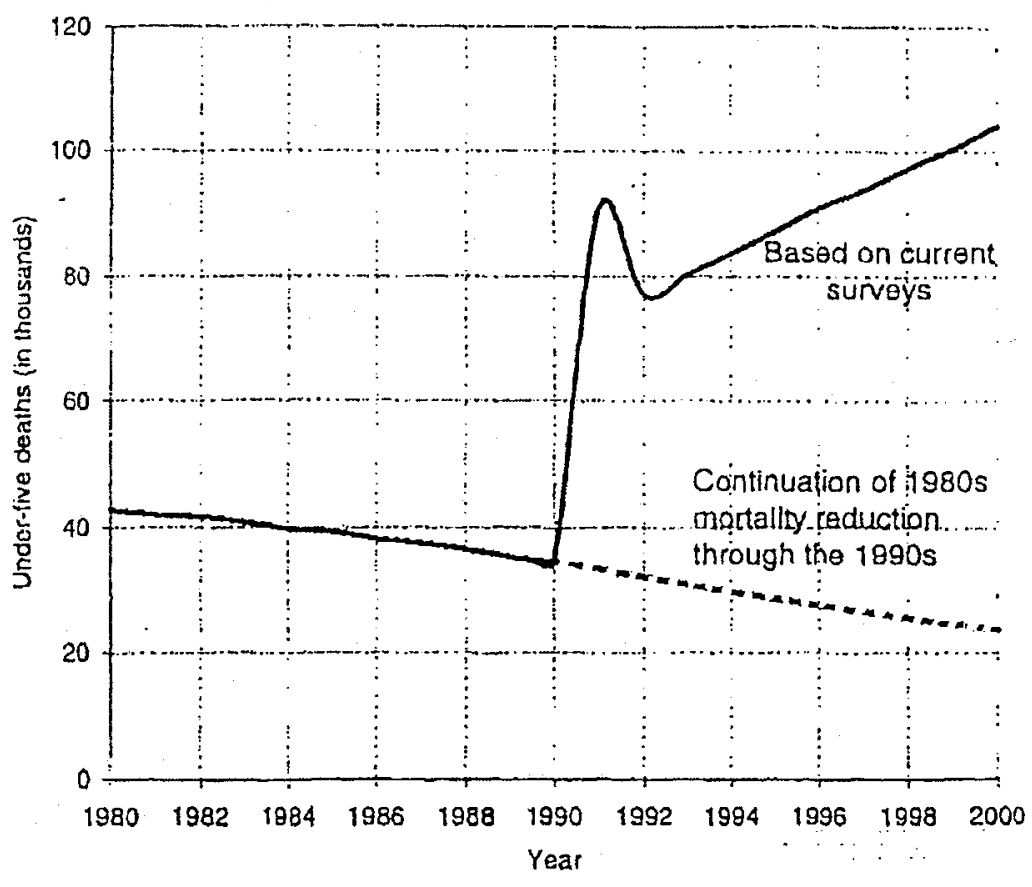

The chart shows the larga disparity batwean under-five deaths based on recent surveys and the number of deaths if the mortality trend in the $1980 \mathrm{~s}$ had bsen continued through tho 1980s. Biths taken from the UN Population Division, World Population Prospects, 1898 revision

UNICEF, August 1999

Child and Maternal Mortality Survey, Iraq 


\title{
APPENDIX VIII:
}

\section{Iraq Sanctions: What Options Did the UN Security Council Have?}

\author{
Hans-C. von Sponeck
}

\begin{abstract}
Economic sanctions imposed by the UN Security Council on Iraq in 1990 were legal; the implementation of sanctions in the following years turned out to be increasingly in violation of the UN Charter and other international law. The impact of UN sanctions policy on the welfare of the Iraqi people was punitive and destructive.

The UN Security Council did not exercise its oversight mandate in a continuous and consistent manner but was nevertheless fully aware of the state of physical and mental ill-being of the Iraqi civilian population.

The UN Security Council had a wide range of options to ameliorate the human condition but succumbed to a hard-line approach preferred by two of its permanent members. Some of these options would have led to minor improvements to the welfare of the Iraqi people, e.g., the introduction of the commercial clause in oil-for-food programme contracts; the agreement of local purchases for the sanctions food basket; the introduction of a cash component to underpin the humanitarian exemption in different sectors.
\end{abstract}

Other options, if adopted by the UN Security Council, would have made significant and life saving differences for the civilian population, e.g., the de-linking of economic sanctions and the military embargo; the de-bureaucratization of procurement of humanitarian supplies; the increase of permitted financial resources for the oil-for-food programme based on needs assessments and a sanctions strategy; a defined unified management structure involving all UN parties charged with the implementation of sanctions in Iraq, etc.

Since these and other more humane options were not chosen despite the knowledge in the UN Security Council of the ensuing human catastrophe, an analysis of the UN's role in the Iraq conflict during the period of economic sanctions reveals elements of intent and therefore willful violation of international humanitarian and other law.

\section{Part I: Introduction}

Throughout the period of Iraq economic sanctions (1990-2003), UN member states, including the US and the U.K., the UN Security Council, a multitude of other intergovernmental organisations such as the League of Arab States including Kuwait and 
Saudi Arabia, the International Red Cross and Red Crescent Societies, the ICRC, the Vatican and religious organisations, the international peace movement and civic leaders vociferously expressed their concern for the welfare of the Iraqi people. Everyone with a voice wanted to assure the world that it was the Government of Iraq that was the target of sanctions and not an innocent population. This is where global solidarity and rhetorical unity on Iraq ended.

How to deal with the Iraq conflict was a different matter. For some the survival of a human being was the challenge and much was done to protect such individual life. Others were active in helping to maintain the social infrastructure and health services. Still others were eager to support the many internally displaced in all parts of the country. A good number devoted their resources to visit Iraq and research and report on the human condition as it evolved under economic sanctions.

What these groups and individuals had in common was a deep sense of justice, compassion, morality and courage. This can not be said for the political world of governments including the Organisation of the Islamic Conference (OIC), the League of Arab States and the European Union. Divided within, unsure, short-sighted, illinformed, unprincipled - any or all of these characterize these political organisations. This ultimately resulted in their inability to make a difference in solving the Iraq crisis peacefully and in accordance with the UN Charter. Political decision making was located elsewhere, in New York, Washington, London and Baghdad.

The UN Security Council should have been the venue to which all the protagonists would come together to debate conflict resolution. This was not to be. The UN Security Council became a tool of bilateral interests. Over the years, the Council distanced itself more and more from its role as a peace maker. It has to be said here that the Security Council did at times pause to introduce measures for the benefit of the Iraqi people. This, however, was usually done under pressure and as an act of last resort. The Iraqi people were treated as expendable commodities as the latest version of the 'Great Game' unravelled. The UN Security Council had succumbed to hardliner and self-serving policies of primarily two of its permanent members. For this the Iraqi people and the United Nations paid a heavy toll.

Part II identifies 22 distinct issues of relevance for the human condition in Iraq for which an independent UN Security Council could have found humane options. It will remain the Security Council's legacy that it chose not to pursue these options.

The renewed debate about a United Nations that is equipped to handle complex international crises in adherence to the UN Charter and other international law has no choice but to carefully take into account what went wrong and why in the UN Security Council's and to a lesser extent the UN Secretariat's handling of the period of economic sanctions in Iraq. 
Part II: Options of the UN Security Council for the Implementation of the Humanitarian Exemption for Iraq

Option 1: Finance for Survival (1991-95)

i. During 1991-95 the UN mounted so-called Inter-Agency Humanitarian Appeals for donations to provide humanitarian assistance to Iraq in order to mitigate the worst effects of sanctions. The UN was hoping to collect an amount of $\$ 1.2$ billion during this period, yet, the funds actually received were only $\$ 450$ million.

ii. The resulting severe shorffall of such voluntary donations led to a quick deterioration of conditions of life in Iraq as evidenced by rising malnutrition, mortality and re-emerging diseases such as erasmus, kwashiokor, measles and cholera.

iii. A more humane option would have been to appeal for international voluntary donations to be supplemented by contributions by member governments to make up any short falls of the funds needed. This would have been a responsible and human rights-minded approach on the part of the UN Security Council keeping in mind that socio-economic conditions were deteriorating because of the imposition of economic sanctions. Such an approach would have resulted in lower mortality, particularly among children, less malnourishment and better epidemiological conditions.

Option 2: Needs Assessment and Financial Allocations

i. Following Operation Desert Storm in January-March 1991, the UN Secretariat mounted two missions to Iraq to assess war damages and the ensuing humanitarian needs of the civilian population. The first mission, led by Marti Athisaari, took place in February 1991; the second by Sadruddin Aga Khan in June 1991. Both visits were important attempts to prepare for subsequent UN Inter-Agency Humanitarian Appeals. In stark terms they identified the extent of the deterioration in Iraq and recommended substantial international emergency assistance. The two missions, however, were not equipped to carry out detailed sector by sector quantifications of requirements for immediate and medium term relief. The UN Secretary General, nevertheless, took the proposals of the missions as the basis for defining the dimension of the subsequent relief efforts during the years preceding the oil-for-food programme in 1996. This took into account the likely cost of compensation of claims by state and non-state parties for alleged material losses incurred due to Iraq's invasion into Kuwait. The absence of rigorously collected data of socio-economic needs introduced a relief bias with serious consequences. These were marginally lessened in February 1998 when the UN Secretary General agreed, with the Government of Iraq, to double the permitted oil revenue allocation from a severely inadequate $\$ 2.6$ billion to a slightly less inadequate $\$ 5.2$ billion. During 13 years of economic sanctions the UN Secretariat did not carry out any overall quantification of needs nor establish the funding levels required to meet such needs. Needs updates were limited to sporadic sectoral reviews. A reliable relief basis, therefore, never 
existed. The absence of a relief strategy with a built-in revision mechanism further weakened the effectiveness of the oil-for-food programme. Throughout the period of sanctions the humanitarian exemption remained a programme conceived as a 'short' term emergency response. The six-monthly distribution plans jointly prepared by the Government of Iraq and the United Nations were little more than shopping lists. The oil-for-food programme, during the first six phases (1996-1999), was wholly dependent on set allocations. Beginning in 2000 with phase VII an established oil revenue ceiling for the humanitarian exemption was removed by the UN Security Council but remained entirely dependent on world market oil prices and ,therefore, constituted no improvement.

ii. Inadequate allocations with funding ceilings based on qualitative rather than quantitative needs assessments followed by open-ended oil production with relief revenue dependent on oil prices created a weak and, as of phase VII, highly volatile resource basis. Funding uncertainty combined with constraints such as bureaucratic procurement, withheld supplies, and the absence of a relief strategy had serious consequences for the Iraqi population.

iii. A more humane approach would have been based on a careful quantitative assessment of needs and a provision for regular integrated and holistic updates with guaranteed finance. This would have ensured that the impact of UN Security Council sanctions policies on the welfare of the Iraqi people would not have been punitive and been in accordance with international law.

\section{Option 3: The Oil Ceiling}

i. Pressure to increase the severely inadequate financial resources for the humanitarian exemption mounted soon after the oil-forfood programme became operational in December 1996. In 1998 permitted oil revenue was doubled yet remained inadequate. In late 1999 there was a special one-time additional allocation for phase VII (2000) followed by the decision to remove the previously prevailing oil ceiling altogether. This decision constituted a political ploy since the UN Security Council was well aware that Iraq' s oil industry was in a "dangerous and lamentable" state as the UN Secretary General was told year after year by oil sector UN review missions who visited Iraq annually. Production figures before and after the oil ceiling was removed in 1999 document the fact that the capacity of the oil industry had reached a peak of 2.1 to 2.2 million barrels per day long before the ceiling was lifted. Output could not increase until a full rehabilitation of the oil industry would take place. This did not happen until the 2003 invasion. By removing the oil ceiling, hardliners argued that since the Iraqi Government consequently faced no more output restrictions, the authorities could earn as much oil income as was required for meeting the needs of the people. The Government of Iraq was entirely to be blamed if the people of Iraq continued to suffer. This constituted a false and malicious statement for reasons explained above. 
ii. The shiff from predictable inadequacy due to output restrictions to alleged adequacy because of 'unrestricted' oil production introduced a further element of income uncertainty. The UN Security Council had changed nothing for the better.

iii. A more humane option would have been to agree to major repairs of Iraq's up- and downstream oil facilities to allow an increase in oil production commensurate to the basic needs of a civilian population.

Option 4: Distribution Plans and Oil Revenue

i. During the period 1996-2003, there have been 13 phases of six months each and an equal number of distribution plans. These plans were prepared in Baghdad by the government of Iraq and the United Nations. Priority in the designation of resources for individual sectors included in the oil-for-food programme (food/nutrition, health, water, sanitation, electricity, agriculture, education, and as of 2000 , construction and telecommunication) as well as allocations for the oil industry was at all times given to the sectors of food and health. In the initial phases, these two sectors would absorb about $80 \%$ of available funds The balance would be allocated to the remaining sectors. It is important to stress that during all 13 phases there was no congruence between the planned and the actual budgets. During most of the phases, the actual budgets reflecting the oil revenue earned would be significantly lower than the planned budgets. The consequence of this was that the oil-for-food programme, as planned for an individual phase and approved as such by the UN Secretary General, most of the time could not be implemented because of a lack of resources. There was no provision in the UN Iraq sanctions policy to augment the actual oil revenue with additional resources to compensate for shortfalls to ensure that a distribution programme was fully funded. Individual phases depended wholly on the volume of oil exported and the world market price of oil. This introduced an income uncertainty factor with serious implications for the welfare of the Iraqi population. The income and supply distribution picture for phase V (1998), to cite one example, illustrates the dilemma for the oil-for-food-programme: the distribution plan called for US\$2.7 billion, available for the humanitarian exemption were only US\$1.9 billion. The resource shortfall was further aggravated by the bureaucratic procurement system and supplies blocked by US and U.K. representatives in the UN Sanctions Committee because of their alleged dual-use nature. This explains why humanitarian supplies worth only US\$ 1.4 billion or just over half of the budgetary provision made in the distribution plan arrived in Iraq during phase $\mathrm{V}$.

ii. Income uncertainty combined with significant delays in the arrival of humanitarian supplies and blocked supplies as well as the refusal of the UN Security Council to make up shortfalls from other sources created untenable inadequacies for the Iraqi population. 
iii. A more humane option would have been for the UN Security Council to guarantee funding once it had accepted distribution plans approved by the UN Secretary General. Voluntary contributions or loans could have provided the funds needed to make up shortfalls. This would have protected the civilian population against the worst effects of inadequacy and prevented death and destitution.

Option 5: Dedicated Budgets

i. Education was one of the sectors included in the oil-for-food programme from the very beginning in 1996. It was the sector that received the remnants of allocations when the distribution plans were negotiated between the Government of Iraq and the United Nations. Other sectors such as food and health, water, sanitation and electricity had to be given priority. At the end of the oil-for-food programme (phases I-XIII) in 2003, the allocation for education requested by the Government of Iraq and approved by the UN Secretary General amounted to US $\$ 2.1$ billion or about $5 \%$ of the total requested allocation. The amount ultimately allocated was even lower. Prior to the oil-for-food programme period, i.e., during the years 1990-96, there was no dedicated allocation of international funds for education. The UN Security Council showed no concern for the consequent destruction of the education system. While the plight of the education sector was raised occasionally by individual members of the UN Security Council, there was at no time a comprehensive debate of this serious issue. In fact, individual members, in the forefront the US and the U.K. governments, intensified the problem by adding harsh bilateral measures in an effort to prevent educational materials from reaching Iraq.

ii. Sanctions, lack of resources and low priority given to education by the Government of Iraq accelerated the deterioration of primary, secondary and tertiary education in the fifteen governorates under control of the Government in Baghdad. The circumstances in Iraqi Kurdistan were somewhat better.

iii. A more humane option would have been for the UN Security Council and the UN Secretariat to provide dedicated finance for the education of Iraqi children, at least at primary and secondary school levels. A shortage of oil revenue could have been made up by extra-budgetary support out of international donations or the unfreezing of Iraqi accounts held abroad. This would have allowed more adequate support for teacher training, educational aids, curriculum development, maintenance and construction of schools, etc. and to some extent provided youth with the means to prepare for life.

Option 6: The Linkage of Economic Sanctions and Disarmament

i. One of the fundamentals of the UN Security Council's sanctions policy for Iraq (resolution 687/1991) had been to make the lifting of economic sanctions conditional to Iraq's destruction of its weapons of mass destruction. The US 
and U.K. authorities refused to discuss a possible de-linking of the two as they believed economic sanctions would deprive Government from the means of rearming with weapons of mass destruction. The linkage meant that the Iraqi civilian population was forced to pay for the conflict between their government and the UN Security Council.

ii. This economic sanctions-disarmament linkage throughout the embargo period had a devastating impact on civilian life in Iraq as is reflected by the respective socio-economic indicators.

iii. A more humane option would have been to delink economic sanctions from disarmament demands by proceeding with UN supervised disarmament and verification programmes while at the same time providing the UN with comprehensive border inspection authority for all consignments destined for Iraq. Additionally, the team of UN observers could have been strengthened to monitor the distribution of all items which had been cleared for entry into Iraq and to confirm their deployment for civilian purposes. This would have allowed a freer flow of supplies needed for survival while at the same time reducing the opportunity for illegal imports.

Option 7:Economic Sanctions Policy

i. Parliaments, non-governmental organisations and the UN Secretariat are on record to repeatedly have reminded the UN Security Council and other policy makers that no country had ever been subjected to such comprehensive sanctions as was the case in Iraq. In view of the serious impact on the civilian population an urgent review of the economic sanctions policy was required. Special mention is made here of reports by the UN Panel on Humanitarian Issues, the so-called "Amorim Panel" (March 1999) the U.K. House of Commons (January 2000), Caritas International (2001), and the Bossuyt report to the UN Human Rights Commission (June 2000). These reports are among many others which alerted the UN Security Council that its sanctions policies were causing severe harm to an innocent population. The sanctions were transgressing the boundaries between acceptable discomfort of civilians and a breach of international conventions created to protect individuals and groups against maltreatment.

ii. The maintenance of such comprehensive sanctions resulted in permanent disability, death of many and the impoverishment of the majority of the Iraqi population.

iii. A more humane option would have been to lessen economic sanctions incrementally in response to cooperation by the Government of Iraq or preferably in response to the evolving needs of the Iraqi people.

Option 8: Procurement of Humanitarian Supplies

i. Procuring goods under the oil-for-food programme was, at all times, cumbersome. The routine required no less than 23 steps that the importer - the 
Government of Iraq - and the supplier in the exporting country had to implement. Involved were inter alia trade, defence and foreign ministries, trade boards, the exporting country's permanent mission to the UN, Iraq's mission to the UN, the UN Office of the Iraq Programme in New York, the UN Office of the Humanitarian Coordinator in Baghdad, the UN Sanctions Committee, the UN Special Commission (UNSCOM/UNMOVIC), and the International Atomic Energy Agency (IAEA), the two disarmament units, transport agencies, Lloyds/Cotecna, the inspection agents at Iraq's borders, and, of course, Iraq's Ministry of Trade and the Iraqi end users. Soon after the oil-for-food programme commenced in 1996, it became clear that such bureaucratization of procurement would lead to serious and disabling delays in the arrival of humanitarian supplies. Delays of 12 or more months were not uncommon. The various phases of the oil-for-food programme, not surprisingly, over time became more and more disjointed. The procurement process was a major factor. Evidence of the negative impact mounted and finally in 1999 resulted in the introduction of a so-called "green list" which identified goods that could be brought into Iraq under the oil-for-food programme without having to be subjected to clearance by the UN Sanctions Committee. This did not improve the overall speed of delivery. The UN Sanctions Committee was urged to make further amendments to accelerate delivery. In 2002 the UN Sanctions Committee replaced the "green list" with a "red list". This was a negative list of items that were potentially of "dual use" or had other strategic value. Items on this list were subjected to the traditional screening. The balance of requested goods could be imported with less scrutiny. This approach in itself could have improved supply conditions but in the end did not because concurrently the US and U.K. representatives in the UN Sanctions Committee significantly increased the volume of items that were permanently or temporarily blocked from delivery to Iraq. In phase IX (2002), \$5.1 billion of humanitarian supplies were blocked by the US/U.K. representatives in the UN Sanctions Committee. In short, the positive "red list" approach meant to de-bureaucratize procurement was negated by the act of blocking goods at a higher rate than before (see annex 7).

ii. The inadequately financed oil-for-food programme was further weakened by special constraints such as bureaucratization of the procurement process. A population highly dependent on timely arrival of limited humanitarian supplies became the victim of a deliberate international bureaucracy.

iii. A more humane option would have been to establish a red list approach from the very beginning of the oil-for-food programme. Consistent with international humanitarian law, a "no list" approach for food and medicines should have been an integral part of the regulatory framework. The UN Sanctions Committee should have furthermore agreed to local purchase of food. This would have allowed the inclusion in the food basket of fresh fruits, vegetables and meat and reduced the cost for food as locally purchased food items were significantly cheaper than imported ones. Such an approach would have freed resources for other sectors and helped to preserve life and livelihood. 
Option 9: The UN Sanctions Committee

i. The Iraq Sanctions Committee of the UN Security Council or the 661 Committee named after resolution 661 of 6 August 1990 was charged with oversight of the implementation of UN Security Council policy. The committee was staffed by middle level officials of the countries represented at any one time in the Security Council and chaired by an ambassador appointed by the UN Security Council. Decision making was by consensus. It quickly became apparent that this committee chose to micro-manage the operational aspects of the oil-forfood programme instead of delegating operational functions to the UN Office of the Iraq Programme (OIP) at the UN Secretariat. In the initial phases, the Committee decided to involve itself in the processing of all humanitarian supplies for Iraq including even those for NGOs operating outside the oil-forfood programme. In doing so, the Committee began to neglect the monitoring of the impact of the operational programme on the human condition in Iraq. Much time was devoted to fine tuning the sanctions bureaucracy and to oversee/control the activities of the UN Secretariat in New York and Baghdad. When the Committee realized that it was creating an increasingly unmanageable workload for itself as well as for the UN Secretariat with the negative consequences for the Iraqi people pressure increased to simplify the procurement process (see also annex 4). The 661 Committee transferred itself into an experimentation chamber in which new approaches were tested as has been pointed out earlier. As criticism over the Committee's micro-management approach and the blocking of supplies by the US and U.K. representatives mounted, the Committee decided to pass clearance responsibility to UNSCOM/UNMOVIC and IAEA, the UN entities which were tightly controlled by the US and U.K. governments. This was an unethical move. It meant that the two governments were no longer directly involved in the clearance of supplies. They could therefore argue that responsibilities for delays of most supply clearances were due not to the 661 Committee but due to the UN Secretariat. In fact, the two governments continued to exercise close informal control.

ii. The UN Security Council Sanctions Committee was a supervisory tool for the UN Security Council. However, instead of supervising the implementation of Council policies for Iraq it controlled and micro-managed the oil-for-food programme. This resulted in duplicating much of the work of the UN Secretariat. It also significantly slowed down the processing of essential supplies for the civilian population. Links of the Committee with a UN interagency working group at UN Headquarters and some contact with the NGO community in New York was useful at the operational level but made little difference at the policy level.

The issue of a sanctions strategy, networking among UN sanctions units, funding, streamlining of procurement, reporting on the human condition rather than only the oilfor-food programme, comprehensive oil production oversight, integrated audits, all 
major factors for responsible implementation of multilateral sanctions were neglected by the UN Sanctions Committee. In retrospect it can be said that the UN Sanctions Committee was little more than an overseer of a supply programme informally controlled by the US and U.K. authorities. Much suffering and destitution among the Iraqi civilian population was due to the approach the UN Security Council had chosen for the working methods of its Sanctions Committee.

iii) A more humane option would have been for the UN Security Council to empower the Iraq Sanctions Committee with authority to monitor the operational and managerial soundness of the work of the UN System. More important than this would have been a continuous review of the impact of UN policies on the welfare of the Iraqi people with regular feedback to the Security Council. Such feedback should have included guidance for the Security Council on needed policy changes in the light of developments in Iraq.

\section{Option 10:Import And Export Controls}

i. Under economic sanctions, all imports and exports to and out of Iraq were banned except as decided by the UN Security Council. To facilitate the permitted export of oil, the UN Security Council identified pipelined export across the border with Turkey to the Mediterranean Port of Ceyhan and the loading of oil at Mina al Bakr, an oil platform in the Persian Gulf. For the import of humanitarian supplies four Iraqi border crossings were designated with Jordan at Trebil, with Syria at al Walid, with Turkey at Zhako, and at Um Qasr, Iraq's only sea port. In 2001, a fifth border point with Saudi Arabia at Ar'ar was added. The United Nations designated an inspection agency (Lloyds Register/U.K. until 1998, followed by Cotecna/Switzerland from 1999 to 2003). They were to verify documentation of oil-for-food supplies with consignments arriving at the designated border points. The UN Security Council was well aware that this left the increasing inflow of goods, the Government of Iraq was purchasing outside the humanitarian exemption as permitted by the UN without international inspection.

ii. The UN Security Council was furthermore aware of oil exports to Jordan under special arrangements between the Iraqi authorities and the Government of Jordan. The UN Security Council did not give approval to these exports under article 50 of the UN Charter which recognizes special economic problems which may arise for countries adjacent to countries under sanctions. The UN Security Council, however, condoned these oil transactions between Iraq and Jordan. The volume of illicit oil exports from Iraq increased over time, first via the Persian Gulf and Turkey and then via a pipeline which Iraq and Syria had agreed to re-open following improved political relations between the two countries from 2001 onwards.

This inconsistent handling of import and export controls on the part of the UN Security Council was used by the US and the U.K. authorities to argue in the Security Council 
that they did not have any accurate information on what the Government of Iraq was importing and exporting. This was particularly so after the UN weapons inspectors had been withdrawn in December 1998, prior to the Anglo-American "Operation Desert Fox". This in turn led to US/U.K. insistence that Iraq was successfully developing new weapons of mass destruction.

ii) The inconsistent approach on the part of the UN Security Council and the resulting alleged uncertainty about Iraq's import and export transactions was not unwelcome to the US/U.K. administrations and served as their rationale to resist a re-design of the economic sanctions strategy which would have benefited the people of Iraq.

iii. A more humane option would have been to enforce strict border controls for all imports and exports, not just those relating to the humanitarian exemption. An increase in subcontracted inspection personnel at the border entry points, more UN oil overseers in Iraq and oil flow analysts in New York plus more authority for UN observer personnel in Iraq would have been measures useful for creating a more transparent supply picture and have helped to constrain the illicit export of oil. More transparency would have revealed that Iraq was not clandestinely manufacturing new weapons of mass destruction. This in turn could have eased the international apprehension about the threat Iraq was posing and lead to improvements in the UN sanctions regime. The civilian population would have benefited in multifarious ways from such an approach (more financial resources, more humanitarian supplies, enhanced international confidence building, etc.).

\section{Option 11: UN Security Council and UN Secretariat Oversight}

i) In the course of time, the UN Security Council has become the omnipotent body in the decision making structure of the institution. There is concern among an increasing number of UN member countries that the UN Security Council has usurped authority from the UN General Assembly and the International Court of Justice. They would like to consider this development as part of the UN reform debate. It can not be denied that the division of labour between these three entities has become less and less clear over the years. This has had serious consequences requiring clarification and transparency of mandate.

As a result of this reality, the UN Security Council unquestionably had the major oversight responsibility for developments in Iraq during 13 years of sanctions. More specifically, it had the mandate to continuously assess the impact of its sanctions policies on the human conditions in Iraq. The UN Secretariat, subsidiary to the UN Security Council had operational oversight responsibility and consequently also the duty to advise the UN Security Council on the implications of sanctions. The Secretariat did engage, to some extent, the Council in policy reviews and operational matters, e.g., the bureaucratization of procurement of humanitarian supplies. 
It, however, is important to point out that both the Council and the Secretariat failed to carry out their oversight mandates in a consistent and continuous manner. As stated elsewhere, the Council failed to debate issues of fundamental consequence for the Iraqi people such as the flow of vital supplies, the use of oil revenue for compensation, the blocking of supplies and the no-fly zones, to name only a few major areas which needed to be discussed in the Council. More importantly these areas needed to be assessed through permanent monitoring and evaluation. This did not happen. Neither did the Secretariat fulfill its mandate to watch over the dynamics of the oil-for-food programme or show imagination and foresight for maximizing the benefits of a severely limited humanitarian exemption. Local purchase of food and other items, integrated implementation of the programme in areas under the control of the Government in Baghdad and the Kurdish locally autonomous regions of northern Iraq, e.g., with respect to electricity, water supply, agricultural production and de-mining are examples where the Secretariat could have shown leadership but did not. The Iraq policy group at UN Headquarters, chaired by the UN Deputy Secretary General, meant to exercise operational oversight, made no difference at all in determining the direction of the humanitarian exemption. This policy group did not even manage to bring about an implementation strategy or joint approaches of the various UN entities charged with different aspects of sanctions implementation ( UNSCOM/LAEA - disarmament, UNOHCI/OIP - humanitarian exemption, UNCC - compensation, UNHRC - human rights) or more broad-based reporting on the human condition in Iraq.

ii) Lack of oversight at various levels of the UN (Security Council, Secretariat, individual UN departments such as DPA, OIP, OCHA, DPKO, etc.) allowed disjointed approaches, neglect of an oversight strategy, misleading reporting and bilateral misuse. This serious default, particularly on the part of the UN Security Council, lessened the pressure on the Council to understand the full scope of the consequences of inadequate measures for the welfare of the civilian population and, therefore, contributed to death and destitution.

iii) A more humane approach would have been to implement a clearly formulated sanctions strategy based on a pre-sanctions human condition profile of Iraq. Such a strategy would have had to be subject to continuous oversight by the Security Council and reinforced by an Iraq watch group at the UN Secretariat closely linked to the UN Humanitarian Coordinator in Baghdad. The main objective would have been to ensure that the required inputs would have been available at all times to meet the needs of the civilian population.

\section{Option 12: Integrated UN Sanctions Management}

i) Different UN entities had operational responsibility for four distinct elements of the UN Iraq sanctions programme: The UN Special Commission (UNSCOM) - after 2000 renamed the UN Monitoring, Verification and Inspection Commission (UNMOVIC) and the International Atomic Energy Agency (IAEA) for disarmament and arms 
monitoring; the then UN Human Rights Commission (UNHRC) and its rapporteur for reporting on human rights in Iraq; The UN Compensation Commission (UNCC) for administering and processing claims against Iraq for having invaded Kuwait and the UN Office of the Iraq Programme (OIP) and the UN Office of the Humanitarian Coordinator for Iraq (UNOHCI) for negotiating the oil-for-food programme and overseeing its implementation.

As the activities within any of these four components impacted on the others, it follows that systematic and continuous networking for conflict resolution/containment and protection of an innocent population should have been of paramount importance and a pre-determined part of UN sanctions management.

Throughout the period of sanctions such networking was absent. The Iraqi policy group at UN Headquarters had no outreach to the four components and was, therefore, ineffectual in giving direction to the Iraq operations. It must be considered as one of the great failures of the United Nations Security Council that it did not insist on networking among the four components or on the definition of an integrated sanctions implementation strategy.

ii) The isolationist approaches of the disarmament group, the compensation unit and the human rights and the humanitarian entities meant that policies were implemented by individual UN units which fostered developments in Iraq that ran completely counter to the principles and purposes of the United Nations. This intensified the collapse of a nation.

iii) The more humane option would have been to ensure integrated approaches among the different UN sanctions groups. This should have included continuous feedback to the UN Security Council to assist the Council in fulfilling its oversight mandate and to allow it to adjust its policies for the protection of the Iraqi people and the adherence to international law. Such an approach would have reduced mortality, disease and destitution in Iraq and upheld the integrity and lawfulness of the United Nations.

\section{Option 13: Pre-Sanctions Preparations}

i) Comprehensive economic sanctions were imposed on Iraq on 6 August 1990 by UN resolution 661. Neither at that time nor in the ensuing period up to the second Gulf War (GWII) in early 1991 was there any attempt by the United Nations to define the socio-economic profile of the Iraqi population as it existed prior to the imposition of sanctions. Within six months following GWII, the UN Secretary General dispatched two important assessment missions to Iraq ( see option 2). Valuable as these missions were, they limited themselves to rough damage reviews and estimations of needs rather than more in-depth quantitative assessments of the then prevailing socioeconomic situation in Iraq in comparison to the status quo ante prior to August 1990. 
Sanctions are meant to hold perpetrators and not innocent groups accountable. The objectives of UN humanitarian assistance in Iraq therefore should have been to ensure that the civilian population would not be forced into living conditions that were significantly below those prevailing prior to sanctions. Without a pre-sanctions assessment or at least a condition analysis in the early 1990s, this was not possible.

ii) The absence of a pre-sanctions assessment and a quantitative needs assessment in the early stages of economic sanctions put the humanitarian exemption on a footing which in its inadequacy had grave consequences for the Iraqi people.

The strong case which recently has been made for pre-sanctions assessments as mandatory prerequisites for the imposition of UN sanctions (see "Sanctions Assessment Handbook" published by the United Nations in October 2004) underlines the awareness that the Iraq sanctions experience has created for the importance of such an approach. Had such an approach been adopted in the case of Iraq much suffering could have been prevented.

iii) A more humane approach would have been to base the humanitarian exemption on a careful pre-sanctions assessment followed by continuously updated evaluations of the evolving conditions of a society living under economic sanctions.

\section{Option 14: Public and Informal Meetings of the UN Security Council}

i) The Provisional Rules of Procedure of the UN Security Council specify that unless the Council decides otherwise meetings shall be public meetings (Rule 48).

Governments which were not members of the Security Council would therefore be able to participate in such meetings, if they wished. Such a provision was in the spirit of a body created to solve international conflicts peacefully while it allowed participation of all parties to a conflict to meet. In the case of Iraq, procedures were reversed and meetings in which Iraq policies were decided were invariably classified as 'informal', thus barring Iraq as the targeted state from participating. Furthermore, the Council prevented the UN Secretary General from engaging in a dialogue with the Government of Iraq by invoking the 'seized of the matter' rule. This rule indicates that the Council reserved for itself the right of debate and contact with Iraq until it decided otherwise. This promoted confrontation and disagreement and, as a consequence, severely limited the scope of the UN's role in conflict resolution. (See also German Amb. Tono Eitel's informal presentation to the UN Security Council dated 14 November 2000).

ii) The UN Charter reminds member states that international disputes should be settled by peaceful means (article 2/3) and emphasizes that solutions to a conflict should be sought "by negotiations, enquiry, mediation, conciliation, arbitration and judicial settlement" (article 33/1). The UN Security Council ignored both the spirit as well as the content of the UN Charter and created a special modus operandi for the handling of the Iraq crisis. 
iii) A more humane approach would have been for the UN Security Council to seek public debate with the Government of Iraq. That could have been achieved by inviting representatives of the Government of Iraq to Council meetings at which Iraq was to be discussed and by providing the UN Secretary General with broad policy guidelines to allow him and senior Secretariat staff to engage Iraqi officials in Baghdad and New York in a dialogue on humanitarian and other issues of relevance to the welfare of the Iraqi people. Such an approach would have avoided much confrontation and misunderstanding and promoted confidence building measures. These would have benefited the disarmament process, the oil-for-food programme and ultimately the people of Iraq.

\section{Option 15: Compensation}

i) The UN Security Council, as early as October 1990 , passed a resolution reminding Iraq that under international law it was liable for "loss, damage or injury" as a result of its invasion into Kuwait (see UN/S/Res.674 of 29 October 1990). By mid-1991, the UN Security Council had identified a compensation mechanism and a corresponding fund through which parties (individuals, firms and governments) alleged to have suffered losses as a result of Iraq's 1990 invasion into Kuwait could receive compensation. This established in Geneva what became known as the UN Compensation Commission (UNCC). Funding, the UN Security Council decided, would be based on a "percentage of the value of (Iraq's) export of petroleum and petroleum products" (see UN/S/Res.687/1991). At that time, the Security Council was prepared to allow the sale per year of up to $\$ 2$ billion of Iraqi oil only to finance the humanitarian exemption. Out of this amount, $30 \%$ would be diverted to the compensation fund. This made the allocation for the people of Iraq even more inadequate. The statement included in resolution 687/1991 (para 19) that "this (deduction) would take into account the requirements of the people of Iraq" is tantamount to cynicism. Compensation financing and the inadequacy of funds left for the survival of the Iraqi people were the major reasons why the Government of Iraq and the United Nations could not come to an agreement on an oil-for-food programme until 1995, some five years later. Unlike others, the US and the U.K. Governments saw this as 'evidence' that the Government of Iraq did not care for the welfare of its people.

By mid-2004 the UN Compensation Commission had processed at total of 2.6 million (!) claims valued at $\$ 265$ billion of which it had awarded $\$ 48$ billion and actually paid to claimants $\$ 18.4$ billion. Claims submitted by individuals, firms and governments were in many cases justifiable, in other cases they were inflated or fraudulent. Documentation to this effect is available.

ii) In the absence of an integrated approach on the part of those dealing within the United Nations with various aspects of sanctions and in view of the secretive manner of UNCC operations, the large diversion of funds went largely unnoticed. Up to the March 2003 illegal invasion into Iraq, some $\$ 17$ billion had been diverted from the oilfor-food programme to the compensation fund. 
In the late 1990s, the mortality rate for children under five years of age, according to UNICEF, had surged from $25 / 1000$ in the 1980 s to $100-120 / 1000$ children. The large funds transferred to the UNCC, had they been available for humanitarian programmes, would not have remedied the health problems facing the Iraqi population living under sanctions. They would have, however, helped large numbers to survive and to be healed. The UN Security Council's agreement to allocate initially $30 \%$ (after 2000 $25 \%$ ) of oil revenue for compensation payments at a time of immense suffering by the Iraqi people must be considered as one of the most serious and far-reaching mistakes made by the Council during the entire period of sanctions.

iii) A more humane approach would have been to establish the principle of compensation, yet, freeze all compensation payments with the exception of claims by guest workers in Kuwait and Iraq who had lost their meager savings. Instead of paying compensation to well endowed firms and governments at a time when Iraqis were dying in large numbers due to a lack of basic supplies and services, these resources should have remained available to the humanitarian exemption.

\section{Option 16: Commercial Clause}

It is part of international business practice for importers to withhold $5-10 \%$ of the payment for a consignment until the goods have arrived and are found to meet specifications, quality and quantity of the order. Such a standard provision was lacking in business transactions with Iraq. In mid-1999, the UN in Baghdad, with support from the UN Secretariat in New York, tried to remove this anomaly from the oil-for-food programme procurement process by introducing such a commercial clause for purchases made for the Iraqi humanitarian exemption. The Government of Iraq was advised by the UN Humanitarian Coordinator to include henceforth commercial clauses in all its contracts. When the UN Office of the Iraq Programme in New York subsequently sought clearance for contracts which contained the commercial clause, US and U.K. representatives in the UN Sanctions Committee in New York refused to clear such contracts. Their argument: the inclusion of such a clause would encourage over-invoicing and provide cash in the hands of the Iraqi authorities which could be used for weapons programmes. This made no sense, of course, since the commercial clause could neither prevent over-invoicing nor other illicit means of obtaining cash. Efforts to protect Iraq against fraudulent business practices failed. Quality controls showed that between 2-3\% of goods procured by Iraq were of sub-standard quality. A commercial clause could have reduced this percentage and given the importer leverage in claiming indemnity.

ii) The absence of a commercial clause constituted an element of vulnerability for the entire oil-for-food programme. Full payment for goods yet to be received encouraged suppliers to neglect standards. Replacing sub-standard goods with goods meeting quality standards became cumbersome and further delayed the arrival of items needed by the civilian population. This unnecessarily intensified deprivation and suffering. 
iii) A more humane option would have been to include the commercial clause as a standard feature in all contracts. Given the inadequate resource situation in the oil-forfood programme, this would have protected resources and accelerated the supply of vitally required goods.

\section{Option 17: Cash Component}

i) Every year governments prepare their recurrent and development budgets in anticipation of the costs arising from running their nations and investing in nationbuilding. Central banks are the custodians of a country's liquid assets. It can not be expected that a country subject to economic sanctions can maintain a normal budgetary process. UN pronounced economic sanctions should have, however, anticipated the need of Iraq for minimum cash resources to be able to meet justified national recurrent expenditure. Civil servants, teachers, hospital staff needed to be paid, infrastructure had to be maintained, embassies required convertible currency. The UN Security Council was aware of these financial requirements. The Council knew that there was no tax income in Iraq. During the years of sanctions, members of the Security Council repeatedly raised the issue of a cash component to become part of the oil-for-food programme. Concern was expressed by UN Agencies and individual governments, including, of course, the Iraqi government. Formal recognition of the importance of cash was finally given by the Security Council in its 1999 resolution 1284 (see UN S/Res/1284, para 24 of 17 December 1999). This should have been a free standing provision applicable with immediate effect. Instead a positive, albeit much delayed, step was once again politicized through a resolution which re-confirmed the link between economic sanctions and disarmament. For the Security Council to include the cash component in a political resolution and for the Government of Iraq to reject this resolution meant for the people that the status quo prevailed. An important opportunity for a betterment of conditions in the country was once again missed. Lack of cash prevented the implementation of a number of important projects included in the health, water, sanitation and education sectors. To give one example: in 1999, the municipality of Baghdad was facing a serious breakdown of the sewerage system in one part of the city. It had to cancel orders for equipment because of a lack of cash for transport and installation. There was a worse fall-out of the continued absence of licit cash. The Government of Iraq had no choice but to increase its clandestine efforts to obtain cash through illegal oil exports, surcharges on contracts and paybacks. It can not be argued that illegal income on the part of the Iraqi Government had nothing to do with Security Council policy. It had. An assessment of the motives for obtaining resources outside the oil-for-food programme has to go beyond the justified criticism of the Government of Iraq for its wasteful expenditures involving construction of palaces and other public buildings, the import of luxury goods and weapons research and development. The need to find resources to run the nation was, however, a major reason for seeking extra funds. A more enlightened and less punitive Security Council approach could have deprived the Government of the justification to proceed as it did. 
ii) The UN Security Council had been well aware of the importance of cash in the implementation of the oil-for-food programme long before adopting resolution 1284 in December 1999. Iraqi Kurdistan already benefited from such a provision in the early stages of the humanitarian exemption. The UN agencies had the authority to hand out cash to local Kurdish contractors, purchase items in the local market and hire local consultants. The UN Secretariat did monitor these cash transactions in Iraqi Kurdistan and could have done the same in the areas under Baghdad's control. That this was not allowed under sanctions rules shows the punitive and double standard approach pursued by the Security Council which the UN Secretariat accepted without protest.

iii) A more humane option would have been to build into the oil-for-food programme in all parts of the country a cash component from the beginning. UN observers and audits could have verified, as they did in Iraqi Kurdistan, the appropriate use of these minor amounts of cash. The availability of cash would have removed one of the impediments in the humanitarian exemption and helped to preserve life and wellbeing.

\section{Option 18: Emergency vs. Rehabilitation}

i) Throughout the thirteen years of comprehensive economic sanctions, the UN, both the Security Council and the Secretariat, referred to the humanitarian exemption as a 'temporary measure' (see for example UN S/Res.986, 14 April 1995). Many debates in the UN Secretariat on the content of the oil-for-food programme ended with the reminder that this temporary measure involved an 'emergency' not a 'development' programme. This UN mindset had considerable implications for the contribution the UN was able to make to the well-being of the Iraqi people. 'Temporary' was also a word politically welcomed by the Iraqi leadership since it gave the impression that sanctions were indeed of a limited duration. It is now common knowledge that the US and U.K. Governments would equate 'temporary' with 'regime change'. Sanctions would end after the downfall of the regime of Saddam Hussein, not before. Linked to this approach was the determination of the Security Council to limit the oil-for-food programme and before it the UN Inter-Agency Humanitarian Appeals to emergency measures rather than over time to a national reconstruction programme.

It is difficult to understand why the UN Secretariat, with all its experience in international development, did not increasingly call for changes in the content of its Iraq programmes. Education, including curriculum development, training and institution building, and sectors such as water supply, sanitation, health services and agriculture constituted areas of need for an innocent population. They had little or nothing to do with dual use or misuse by the government but were vital for survival and the preparedness for life of future generations.

Apart from minor changes, e.g., agreement in early 2000 to carry out limited training for workers in the oil sector, the UN did not abandon the emergency nature of its involvement and considered, for the entire thirteen years, the humanitarian exemption 
as a temporary measure. As a result, both the UN and its agencies as well as the Government of Iraq developed a 'supply and distribution mentality' which permeated all actions thereby severely neglecting all longer term needs of a population.

ii) The UN Security Council and the UN Secretariat must take the responsibility for treating the civilian population as if they were living in a refugee camp. The deliberate inadequacy of financial resources, the deliberate limitation of sectors included in the oil-for-food programme, the deliberate emergency approach rather than a transition over time to national rehabilitation converted Iraqis into a nation of survivors and fixers neglecting planning and preparation for the future. Life for the civilian population became an issue of 'to-day' only.

iii) A more humane option would have been to introduce medium and long-term components into UN supported programmes in those areas which determined the quality of life of the civilian population. The replacement of the emergency nature of UN operations in Iraq would have allowed the civilian population to live a more normal physical and mental life and helped the youth to get a sense of the importance of planning and preparing for life beyond sanctions and the Government of Saddam Hussein.

\section{Option 19: Sanctions Evaluations}

i) Had the UN Security Council and its Sanctions Committee in cooperation with the UN Secretariat, exercised their oversight mandate responsibly, it would not have been difficult to continuously subject UN sanctions policy to a review. Such a review was of particular importance in the case of Iraq since neither the Security Council nor the UN Secretariat had any experience with the implementation of UN comprehensive economic sanctions as imposed on Iraq. There was no precedent. The UN Security Council is privy to a document of the Economic and Social Council dated June 2000 (see UN E/CN.4/Sub.2/2000/33, 21 June 2000) on the 'adverse consequences of economic sanctions on the enjoyment of human rights'. In this document, Professor Marc Bossuyt, a former chairman of the UN Human Rights Commission and eminent lawyer in Belgium's Court of Arbitration, suggests a six-prong test for evaluating the justification and legality of sanctions: 1 . are the sanctions imposed for valid reasons?, 2. do the sanctions target the proper parties?, 3. do the sanctions target the proper goods and objects?, 4. are the sanctions reasonably time-limited?, 5. are the sanctions effective and capable of achieving a desired result?, 6. are the sanctions free from protest arising from the violations of the "principles of humanity and the dictates of the public conscience"?

At no time did the Security Council or the UN Secretariat consider such a test since this would have meant the end of the sanctions programme as devised for Iraq. One can argue whether the sanctions were imposed for the right reasons. They were clearly not targeting the proper parties. They furthermore targeted to a large extent the wrong goods and objects. The sanctions period in terms of the impact on the people of Iraq 
and with respect to international law was not reasonably time-limited. In the early 1990 s, sanctions had achieved the desired results in terms of disarmament. The justification for sanctions against Iraq was questioned by the largest ever global movement of opposition.

The UN Security Council could have introduced a test of this kind, without difficulty and gone beyond it to take into account the emerging needs of a society subjected to long periods of sanctions ( temporary vs. medium and long term needs - see also option 18).

ii) The absence of continuous oversight of any kind by the UN Security Council or the specific evaluation of the impact of its own policies on the welfare of the Iraqi people has put a severe legal and moral burden on the shoulder of the Council, not just on the US and U.K. governments. The UN Secretariat itself could have devised a sanctions effectiveness test, applied it and made its findings available to the Security Council with a request for debate. It did not do so and therefore also shares the burden of failure. Following the publication of the June 2000 ECOSOC document, there was no attempt to discuss the proposed sanctions test. The document was simply ignored. The response of the UN Office of the High Commissioner for Human Rights was timid and without determination to take the report to belatedly pursue the issue of human rights violations by the United Nations as a result of economic sanctions. The absence of structured sanctions analyses played into the hands of the hardliners in the Security Council as the evidence of the serious shortcomings of Council policy remained evasive. The UN Secretariat, UN Agencies active in Iraq and the UN High Commissioner for Human Rights can not explain their passiveness by evoking their subsidiary position to the Security Council. The UN system on the whole regrettably lacked courage and determination. The price for this irresponsibility of an international institution created to protect the innocent was paid by the civilian population in Iraq.

iii) A more humane option would have been for the UN Security Council to ensure that regular sanctions effectiveness tests were carried out by either the UN Sanctions Committee or the UN Secretariat in order to identify the impact of international policy on the human condition in Iraq. This would have allowed remedial actions for protection of the Iraqi people to take place and would have been in compliance with UN Charter and other international law.

\section{Option 20: Outreach to Non-State Parties}

i) Through-out the years of sanctions, non-governmental and inter-governmental organizations other than the UN played an important role in the Iraq crisis. They provided humanitarian support and they became major sources of information on the human condition in the country. The majority of these organizations were located in the Kurdish parts of Iraq. However, there were well-known institutions such as the ICRC and CARE with offices in Baghdad. There were others which did not maintain a permanent presence but had programmes in Iraq, e.g., Caritas and IPPNW. All of them 
had substantial local information on such issues as the water and sanitation situation in rural and semi-urban areas, the state of the school system, public health care outside the big hospitals, etc. This specialized knowledge was often superior to that of the UN System. Additionally, they were not tied to governments in the same way the UN institutions were and therefore tended to be much more straightforward in their reporting of the serious conditions prevailing in Iraq.

The UN Security Council could have made continuous use of their knowledge through cooperation and regular exchanges. It was only from early 2000 onwards that intermittent consultations were arranged by the Security Council with some of these organizations, e.g., the ICRC. Many important opportunities to tap their experience were missed.

In 1999 the Security Council, under pressure of international public opinion and some member governments, decided to establish a panel to look into humanitarian issues ( this was one of three panels set up by the Council under the chairmanship of Amb. Celso Amorim, then Brazil's permanent representative to the UN). Members of the panel were mistakenly all drawn from the UN civil service rather than from non-UN bodies such as Care, Caritas or Red Crescent institutions. This deprived the review process of an experience dimension UN civil servants did not have.

Cooperation between the UN Secretariat and resident non-UN organizations in Iraq was tenuous and at times even acrimonious. The UN did not have a systematic cooperation policy, leaving it largely to the local UN representatives to define the degree of collaboration. Ignored by the Security Council and underutilized by the UN Secretariat, these institutions carried on in relative isolation and without adequate opportunities to share their relevant experience, or better still, to carry out flanking measures supplementing the oil-for-food programme. Some co-financing in microprojects existed for some time in the water and sanitation sectors, in rural health services, in housing and education and assistance to internally displaced (IDPs).

For a variety of reasons including a perceived political inconvenience on the part of the UN Security Council, the interaction between the UN and non-UN institutions was poor. This was to the detriment of the civilian population.

ii) Non-UN institutions operating in areas under the control of Baghdad as well as in Iraqi Kurdistan performed important survival functions at the local level despite small funding. Rural health clinics were set up, equipped and run, schools were built and supplied with teaching aids, water and sanitation systems were repaired and treatment materials donated. Training programmes, practically absent from the oil-for-food programme, were carried out in many fields. Even though the scope of these efforts was limited, the benefits for people was significant.

iii) A more humane option would have been for the UN Security Council and the UN Secretariat to define a clear policy of cooperation with non-UN institutions for the 
delivery of a humanitarian exemption. The greater flexibility of these institutions could have been used by the UN to fill gaps in the oil-for-food programme in training, institution- building, infrastructural rehabilitation at the local level, etc. Small amounts of extra funding could have been mobilized by the UN Secretariat to intensify cofinancing as an integral part of the humanitarian exemption. Instead, a lack of determination reduced cooperation to an insignificant number of haphazardly identified projects in southern and central Iraq. In the locally autonomous areas of Iraqi Kurdistan cooperation between the UN and non-UN organizations was somewhat closer. Yet, there was no systematic and integrated approach.

Enhanced and planned cooperation would have meant a more efficient use of scarce resources and better protection of the civilian population against the impact of sanctions.

\section{Option 21: The No-Fly Zones}

i) The US, U.K. and French governments decided in 1991/92 to establish two no-fly zones in Iraq north of the $36^{\text {th }}$ parallel and south of the $32^{\text {nd }}$ parallel (as of 1996 the $33^{\text {rd }}$ parallel) to implement 'Operation Provide Comfort' and 'Operation Southern Watch' respectively. These no-fly zones from which France withdrew in 1996 were created unilaterally by these countries outside the UN and, therefore, did not have an international and legal mandate. Throughout the years of sanctions, the US and U.K. authorities evaded a debate on the legality of the two zones arguing that various UN resolutions, particularly resolution 688 (see UN S/Res. 688/1991) had given them the right to introduce these zones. This contention was incorrect. Resolution 688 in its article 5 requests the UN Secretary General "...to address urgently the critical needs of the refugees and displaced Iraqi population"... and appeals to member states "to contribute to these humanitarian relief efforts." Moreover, deriving authority for the establishment of such zones, even if this were appropriate, would not give the two governments authority for the aggressive military behaviour they increasingly displayed in these zones over the years. In any case resolution 688 (1991) was passed under Chapter VI of the UN Charter which is entitled 'Pacific Settlements of Disputes'.

Following the four nights of heavy bombing during 'Operation Desert Fox' of December 1998 by the US and U.K. air forces, benign violation of international law through daily incursions into Iraqi airspace was replaced by increasingly aggressive behaviour of the two air forces under new and enlarged rules of engagement. This development made a mockery of the assertion by the British Ambassador in the Security Council in June 2000 that "the action we take in the no-fly zones is following Security Council 688 to protect the civilian population of Iraq from repression by the Iraqi Government." (see UN/S/4152 ${ }^{\text {nd }}$ meeting, 8 June 2000 , p.4) The year before, such 'protection' resulted in 144 civilian deaths and 446 civilian injured as a result of an 
average of 3 air strikes per week. This information was carefully checked out, often through site visits and recorded by the Office of the UN Humanitarian Coordinator in Baghdad in quarterly reports. These were welcomed by the UN Secretary General, opposed by others in the UN Secretariat and condemned by the US and U.K. governments (see confidential report prepared by UNOHCI/Baghdad entitled: 'Air strikes in Iraq/Reported Civilian Casualties and Damages', 28 December 1998-31 December 1999).

The reality was very different from the one presented by the two governments. Their actions had little to do with concern for human rights of the Kurds in northern Iraq and Shias in the south and a lot with deliberate destabilization of Iraq and in 2002/03 with US/U.K. preparations of a secretly decided invasion.

The issue of the two no-fly zones was raised in the Security Council on a number of occasions but never debated. Russia, China, France, Malaysia and others referred to developments in the two zones, yet were unable to engage the Council as a whole in a debate. The UN Security Council, therefore, must take responsibility for having condoned the illegal behaviour of the air forces of the United States and the United Kingdom throughout the thirteen years of sanctions.

ii) The two no-fly zones did not just lead to death, injury and physical destruction. The frequent air alerts created what Iraqis called a 'siren syndrome'. Civilians, especially children, became fearful of these incursions. In addition, the UN oil-for-food operations were impaired by the aggressive behaviour of the US and U.K. air forces. UN trucks, for example, had to observe curfew hours thus slowing down the distribution of food and other supplies. UN missions had to be off the road during times of expected air strikes. Had there been a genuine concern for the welfare of the Iraqi people, the air forces of the US and U.K. under respective agreements with the Governments of Turkey and Saudi Arabia could have been on stand-by at the Sultan and Incirlik Air Force Bases in the two countries as a non-aggressive reminder for Baghdad of their presence in case of untoward behaviour by the Government of Iraq. Instead much suffering was inflicted on the people of Iraq and the sovereignty of the country was violated despite repeated reminders by the UN Security Council that Iraq's sovereignty had to be respected.

iii) A more humane option would have been to confine the air forces of the US and U.K. to the Sultan and Incirlik Air Force Bases in central Saudi Arabia and south eastern Turkey. Such a policy would not have violated UN Charter law and facilitated the implementation of the oil-for-food programme. Fewer Iraqi civilians would have perished and many would have benefited more quickly from humanitarian supplies.

\section{Option 22: Public Information}

i) During the entire sanctions period the US and the U.K. Governments were involved in efforts to portray a picture according to which they were genuinely concerned with 
the suffering of Iraq's civilian population while the Government of Saddam Hussein did not care for his people. Government's reluctance to conclude an oil-for-food programme in the early 1990s (for reasons they chose not to mention - see option 15), alleged stockpiling of food and medicines and the sale by government of essential supplies on the open markets in Iraq or abroad were cited as examples. At the same time, the two governments chose to ignore to mention that they were the cause of blocking humanitarian supplies worth billions of US\$ (see option 8). They also failed to mention that the existing procurement system for the oil-for-food programme was a master piece of bureaucratization largely due to their making (see option 8). In addition, they delayed the inclusion into the oil-for-food programme of housing and telecommunication components. They repeatedly prevented dialogue between the UN Secretary General and the Government of Iraq. They also objected to briefings from UN staff posted to Baghdad. Also, they were instrumental in changing the rules of procedures for meetings in the Security Council from predominantly public to informal meetings which excluded Iraqi diplomats from participation. They misused the UN disarmament operations in Iraq to collect intelligence information for bilateral purposes. They prevented Iraqi delegations from arriving in time for United Nations events in New York thereby violating an agreement the UN has with the US, as the host country, to allow free travel to New York to attend UN meetings. They also tried to convince senior Iraqi officials traveling to New York to defect.

The US and U.K. Governments periodically published documents to show a picture in Iraq which, at best represented half-truths. In September 2002, as one example, the US Government published a report entitled "A Decade of Deception and Defiance Saddam Hussein's Defiance of the United Nations" which provided false information on Iraq's weapons of mass destruction, the withholding of food and medicines, the financing of Hajj travels, Iraq's sheltering of terrorist organisations, the diversion of dual-use items for military purposes, the contracting of supplies, the extent of cooperation of the Government of Iraq with UN Agencies, etc. The UN Secretariat reports on many of these issues gave a different picture. It had no impact on the statements of the US State Department and the British Foreign Office: "We are doing our best to ease the suffering of the Iraqi people" (see op-ed piece in the U.K. FT of 4 May 2000 by Samuel Berger, the then National Security Advisor).

Dis- and mis-information prevailed throughout giving the impression that the villain resided exclusively in Baghdad and not also in London and Washington.

At the time and very much in retrospect, it reflects a fateful weakness that members of the UN Security Council and senior management in the UN Secretariat did not feel the need to protest these obvious misrepresentations by two permanent members of the Council.

ii) Mis- and dis-information by two permanent members of the UN Security Council about the conditions in Iraq and their causes contributed significantly to confuse the public, particularly but not only in the US and the U.K.. This in turn fostered an anti- 
Iraq climate among groups who might have become more critical of their governments' policies and shown compassion for the plight of an innocent people. The absence of rebuttals and clarifications by the UN Security Council as a whole and the UN Secretariat worsened efforts to improve conditions for the Iraqi population.

iii) A more humane option would have been for the UN Security and the UN Secretariat to issue periodic reports of high quality to the international public that would reflect the actual humanitarian conditions in Iraq as reported by the UN system in Baghdad. Such factual information could have been used by groups and individuals to enhance pressure for improvements in international support for a people under sanctions and signal to the US and U.K. governments that manipulation of facts was unethical, pointless and ultimately politically counterproductive.

\section{Part III: Conclusions}

In assessing the extent of pre-meditated or accidental death, destruction and trauma of the Iraqi population during the period 1990-2003, one must distinguish the policies and acts of different perpetrating parties, i.e., the Government of Iraq, the governments of individual UN member countries, particularly the US and the U.K. and the collective of 15 member countries in the UN Security Council.

As research proceeds, more and more refined and conclusive evidence of perpetration involving different parties is possible. As of 2006, a significant amount of evidence has been accumulated to document crimes against humanity on the part of President Saddam Hussein and his Government. This evidence relates to the treatment of individuals or groups in actual or alleged opposition to the Ba' athist government in Baghdad. A broad picture is visible of crimes against Kurdish and Shi' ite groups including Shia clerics, Marsh arabs (Madan) in southern Iraq and also against Sunni, Turkomen, Armenian and other groups suspected of opposing the government.

To establish details will require, however, significantly more research. New information contained in de-classified documents in various government archives underlines the complexity of establishing culpability. For example, the existence of mass graves in Iraq does not point only to the Ba'athist government as a perpetrator but also to insurgents in the 1991 uprisings in southern Iraq and the 1991 coalition air attacks on Iraqi troops retreating from Kuwait. US Department of Defence documents released in the 1990s put in question whether the use of chemical weapons in attacks on villages in Iraqi Kurdistan involved Iraqi military only or possibly also Iranian troops since cyanide was deployed which Iraqi troops were not known to have used.

Evidence of violation against the Hague and Geneva Conventions, the Convention on the Rights of the Child, the Torture Convention and other international law with regard to the 2003 invasion and occupation of Iraq by a US-led coalition force is available and continues to increase. Much has been written on this period of Iraqi history but comprehensive scholarly legal work has yet to become available. 
More difficult is the assessment of perpetration by individual UN member countries prior to the March 2003 invasion. Planned destruction of civilian infrastructure (roads, bridges, water and sanitation facilities, electricity plants and oil installations, etc.) and the use of weapons of mass destruction such as DU munitions constitute indicators of serious illegality on the part of US authorities. It is unfortunate that to-date the scientific debate on depleted uranium (radiological vs chemical factors) has deflected from the debate about the use of DU. This has postponed the formal admission by perpetrators that depleted uranium is indeed the cause of ill health of Iraqis and members of the coalition forces and genetic damage among their off-spring.

The foregoing review of policy options the UN Security Council has had in dealing with comprehensive economic sanctions in Iraq shows the wide scope the Council had in influencing the fate of a people. The review's focus on the UN Security Council does not in any way abrogate or reduce the responsibilities the Government of Iraq had for the welfare of its citizens. This paper concentrates on the role played by the United Nations. Detractors will argue that this is only half the story. They are correct. But half the story it is and it must be portrayed in as much detail as possible to supplement the other half of the story on which much has been written already. A good deal is known about the violations of human rights by the Government of Saddam Hussein. Little documentation of the punitive nature of sanctions policies of the UN Security Council and the largely passive acceptance of such policies by the UN Secretariat is available. Serious questions have arisen about the legality of policies adopted by the UN Security Council. The UN Security Council has been accused by respected international law experts of having repeatedly and knowingly violated UN Charter law and international conventions. The most serious accusation refers to the UN's alleged violation of the genocide convention. It is argued that many years of awareness by the Security Council of the fatal impact of its policies without changing these policies, ultimately constituted 'intent'. The UN Security Council, they maintain, therefore, violated inter alia article 2 (c) of the Convention on the Prevention and Punishment of the Crime of Genocide which reads:

"deliberately inflicting on the group conditions of life calculated to bring about its physical destruction in whole or in part".

Clarification of the role, motives, impact and intent of the UN Security Council's Iraq policies is long overdue. This paper is a contribution towards this important objective. 


\section{Bibliography}

\section{Books:}

Arnove, Anthony (2000). Iraq under Siege: The Deadly Impact of Sanctions and War. Cambridge: South End Press

Blix, Hans (2004). Disarming Iraq. New York: Random House.

Brownlie, Ian (2003). Principles of Public International Law. Sixth Edition. New York :Oxford University Press.

Bucklin, Steven (2000). Realism and American Foreign Policy: Wilsonians and the Kenneth Morgenthau Thesis. Connecticut: Praeger Publishers

Bull, Hedley (1995). The Anarchical Society: A Study of Order in World Politics. London: MacMillan Press

Crawford, Neta \& Klotz, Audie (ed.) (1999). How Sanctions Work: Lessons from South Africa. New York: St. Martin's Press

Dajani, M \& Daoudi, M (1983). Economic Sanctions: Ideals and Experiences. London: Routledge and Kegan Paul.

Donnelly, Jack (2000). Realism and International Relations. Cambridge: Cambridge University Press.

Doxey, Margaret (Second Edition) (1996). International Sanctions in Contemporary Perspective. United States of America: St. Martin's Press.

Doxey, Margaret (1987). International Sanctions in Contemporary Perspective. New York: St. Martin's Press.

Falk, Richard (2000). Human Rights Horizons: The Pursuit of Justice in a Globalized World. New York: Routledge

Freyberg-Inan, Annette (2004). What Moves Man: The Realist Theory of International Relations and Its Judgment of Human Nature. New York: SUNY Press.

Gowlland-Debbas, V (2001). United Nations Sanctions and International Law. The Hague: Kluwer Law International

Haass, Richard (ed.). (1998). Economic Sanctions and American Diplomacy. New York: Brookings Institutional Press. 
Hasenclever, Andres, Peter Mayer, Volker Rittberger. (1997). Theories of International Regimes. Cambridge: Cambridge University Press.

Hufbauer, Gary \& Schott, Jeffrey (1983). Economic Sanctions in Support of Foreign Policy Goals. Cambridge: MIT Press

Leyton-Brown (ed.). (1987). The Utility of International Economic Sanctions. London: Croom Helm Ltd.

Losman, Donald (1979). International Economic Sanctions: The Cases of Cuba, Israel and Rhodesia. Albuquerque: University of New Mexico Press.

Lopez, George \& Cortright, David (2000). The Sanctions Decade: Assessing UN Strategies in the 1990s. Boulder: Lynne Rienner Publishers

Malanczuk, Peter (1997). Akehurst's Modern Introduction to International Law. London: Routledge.

Morgenthau, Hans (1978). Politics Among Nations: The Struggle for Power and Peace. Fifth Revised Edition. New York: Alfred A. Knopf

Schoenman, Ralph (1992). Iraq and Kuwait: A History Suppressed. California: Veritas Press

Simons, Geoff (1998). The Scourging of Iraq: Sanctions, Law and Natural Justice. Great Britain: MacMillan Press Ltd.

Waltz, Kenneth (1979). Theory of International Politics. New York: McGraw-Hill.

\section{Documents:}

Bossuyt, Marc (2000). "The Adverse Consequences of Economic Sanctions on the Enjoyment of Human Rights." Economic and Social Council: Commission on Human Rights. $52^{\text {nd }}$ Session, $4-41$

Convention on the Elimination of All Forms of Discrimination against Women, 1979

Geneva Convention IV of 1949 and Protocol I of 1977

Hague Convention IV, 1907 (Respecting the Laws and Customs of War on Land).

International Covenant on Civil and Political Rights (1966)

International Covenant on Economic, Social and Cultural Rights (1966) 
International Criminal Court Statute: War Crimes

Universal Declaration of Human Rights

United Nations Charter

United Nations Children's Fund Report (1998). Situation Analysis of Women and Children in Iraq - 1997. $30^{\text {th }}$ April.

United Nations General Assembly Resolution 2444 - Respect for Human Rights in Armed Conflict (1968)

< http://www.un.org/documents/ga/res/23/ares23.htm>

"Legality of the Threat or Use of Nuclear Weapons" United Nations General Assembly Advisory Opinion to the International Court of Justice, 1996.

$<$ http://www.icj-cij.org/icjwww/idecisions/isummaries/iunanaummary960708.htm>

\section{Electronic References:}

- "Depleted Uranium." Iraq Action Coalition. (Information and statistics on sanctions against Iraq and the amount of depleted uranium used during the Desert Storm War)

$<$ www.iraqaction.org $>$

- Graham-Brown, Sarah "No-Fly Zones: Rhetoric and Real Intentions." Global Policy Forum. 20 Feb. 2001

$<$ http://www.globalpolicy.org/security/issues/iraq/flyindex.htm>

- "Power of Veto." Global Policy Forum. (Information on Security Council Power of Veto).

<http://www.globalpolicy.org/security/membship/veto.htm>

- "Shattered Lives: Sexual Violence during the Rwandan Genocide and its Aftermath." Human Rights Watch. 1996. (Human Rights Watch 1994 Report: Information and Statistics on the History of the Genocide in Rwanda)

<www.hrw.org >

- <http://sass.caltech.edu/events/ritter.shtml>

Information on Scott Ritter, Former Chief Inspector of Weapons under United Nations Commission in Iraq

- www.un.org: United Nations Security Council Resolutions <http://www.un.org/Depts/oip/background/index.html> 
- www.unicef.org: (Statistics on mortality rates in Iraq during the sanctions regime) $<$ www.unicef.org/newsline/99pr29.htm> $<\underline{\text { http://www.unicef.org/emerg/iraq/index bigpicture.html - 2004> }}$ $<$ http://www.unicef.org/newsline/99pr29.htm> $<$ http://www.unicef.org/media/media 19237.html>

- www.un.org/depts/oip/background/basicfigures.html Office of the Iraq Programme - Oil for Food website

- "Soft Law and Hard Law" (Binding and Non Binding Instruments of the United Nations)

$<$ www.unesco.org $>$

- www.iie.com: Institute for International Economics website: A Report on the White House food ban in Iraq $<\underline{\mathrm{http}}$ ///www.iie.com/research/topics/sanctions/iraq.cfm>

- www.cam.ac.uk/societies/casi/halliday/quotes.html

Dennis Halliday quoting the horrible consequences of sanctions against Iraq.

- "International Humanitarian Law and International Human Rights Law: Similarities and Differences." ICRC. (Advisory Service on International Humanitarian Law) <www.icrc.org>

- US Department of State on Sanctions Against Iraq $<$ http://www.state.gov/secretary/former/powell/remarks/2002/13324.htm >

\section{Journal Articles and Book Chapters:}

AlNasrawi, Abbas (2001). "Iraq: Economic Sanctions and Consequences, 1990-2000.’Third World Quarterly, Vol. 22:205 -218

Ammash, Huda (2000) "Toxic Pollution, the Gulf War, and Sanctions." In Iraq Under Siege, Cambridge: South End Press. pp: 169 -180

Ammash, Huda et al (1997) "Electromagnetic, Chemical and Microbial Pollution Resulting from War and Embargo, and Its Impact on the Environment and Health," Journal of the Iraqi Academy of Science 44:1 109-122

Bahdi, Reem (2002). "Gender and War: Commentary: Iraq, Sanctions and Security: A Critique.” Duke Journal of Gender Law \& Policy, Summer, Vol. 9: 237-253. 
Bell, Dawn (2004). "International Control of Iraqi Oil: How the Oil-For-Food Program Fits In, and Implications for the Future." Richmond Journal of Global Law and Business. Vol. 4: 129 - 146

Black, David. (1999). "Not Cricket": The Effects and Effectiveness of the Sport Boycott." In Crawford and Klotz, (ed.). How Sanctions Work: Lessons from South Africa. New York: St. Martin's Press

Cosgrove, Erica (1999). "The Sanctions Dilemma and the Case of Iraq: Human Rights and Humanitarian Challenges to the Use of Multilateral Sanctions." Windsor Review of Legal and Social Issues. Vol. 65: 66-97

Cox, Robert (1993). "Gramsci, Hegemony, and International Relations: An Essay in Method." In Stephen Gill (ed.) Gramsci, Historical Materialism, and International Relations. New York: Cambridge University Press

El-Bayoumi, M A (2000). "Sanctions, Strikes, and Oil for Food: Humanitarianism of the 'New' World Order, AAUG Monitor, Vol. 15: 18-27

Gill, T. D (1995). "Legal and Some Political Limitations on the Power of the UN Security Council to Exercise Its Enforcement Powers under Chapter VII of the Charter." Netherlands Yearbook of International Law. Vol. 26: 33 -138.

Gilpin, Robert (1986). "The Richness of the Tradition of Political Realism." In R. Keohane (ed.) Neorealism and its Critics. New York: Columbia University Press.

Gordon, Joy (2002). "When Intent Makes All the Difference in the World: Economic Sanctions on Iraq and the Accusation of Genocide." Yale Human Rights and Development Law Journal, Vol. 5: 57-81

Gordon, Joy. (1999). "A Peaceful, Silent, Deadly Remedy: The Ethics of Economic Sanctions.” Ethics and International Affairs Journal, Vol. 13:123-142.

Hassan, Nausheen (2001). "U.S Involvement in the Sanctions Against Iraq: A Potential Basis for a Legal Claim by Iraqi Woman." Southern California Review of Law and Women's Studies, Fall, Vol. 11:189-232.

Kapstein, Ethan (1999). “Does Unipolarity Have a Future?” In Kapstein and Mastanduno (ed.). Unipolar Politics: Realism and State Strategies After the Cold War. New York: Columbia University Press.

Kochler, Hans (1995). "Ethical Aspects of Sanctions in International Law: The Practice of the Sanctions Policy and Human Rights." In Hans Kochler, Democracy and the International Rule of Law. Propositions for an Alternative World Order. New York: Springer. 
Kozal, Peggy (2000). "Is the Continued Use of Sanctions As Implemented Against Iraq A Violation of International Human Rights?" Denver Journal of International Law and Policy. Vol. 28: 383 - 400

Lake, David (2003). "Reflection, Evaluation, Integration: The New Sovereignty in International Relations." International Studies Review, Vol. 5:303- 321

Maloka, Tshidiso (1999). "Sanctions Hurt but Apartheid Kills: The Sanctions Campaign and Black Workers." In Crawford and Klotz, (ed.). How Sanctions Work: Lessons From South Africa. New York: St. Martin's Press

Marouf, Baha'a (1998). "Pollution with Depleted Uranium in Iraq." Umm Al-Ma'ark. Vol. 16: 129 -134

Melby, Eric (1998). "Iraq." In Richard Haass (ed.). Economic Sanctions and American Diplomacy. New York: Brookings Institutional Press. P. 107-128.

Milner, Helen (1998). "International Political Economy: Beyond Hegemonic Stability." Foreign Policy, Vol. 110: 112 - 124.

Pellett, Peter (2000). "Sanctions, Food, Nutrition and Health in Iraq." In Anthony Arnove (ed.). Iraq Under Siege: The Deadly Impact of Sanctions and War. Cambridge: South End Press, pp. 151-168.

Pejic, Jelena (2001). "The Right to Food in Situations of Armed Conflict: The Legal Framework." International Review of the Red Cross, Vol. 83: 1097 - 1110).

Provost, R. 1992. "Starvation as a Weapon: Legal Implications of the United Nations Food Blockade Against Iraq and Kuwait." Columbia Journal of Transnational Law. Vol. 30: 577-639.

Taliaferro, Jeffrey (1999). "Security under Anarchy: Defensive Realism Reconsidered." International Studies Association Working Paper: $40^{\text {th }}$ Annual Convention in Washington, $D C, 1-22$

Waltz, Kenneth (1986). “Political Structures.” In Robert O. Keohane (ed.). Neorealism and Its Critics. New York: Columbia University Press

Zurbrigg, Sheila and Neil Arya (2003). “Operation Infinite Injustice: Impact of Sanctions and Prospective War on the People of Iraq." Canadian Journal of Public Health. January - February, Vol. 94: 9-12. 
Newspaper Articles:

Sponeck, Hans V. (2002). “Too Much Collateral Damage." The Globe and Mail, Toronto, July $2^{\text {nd }}$. 